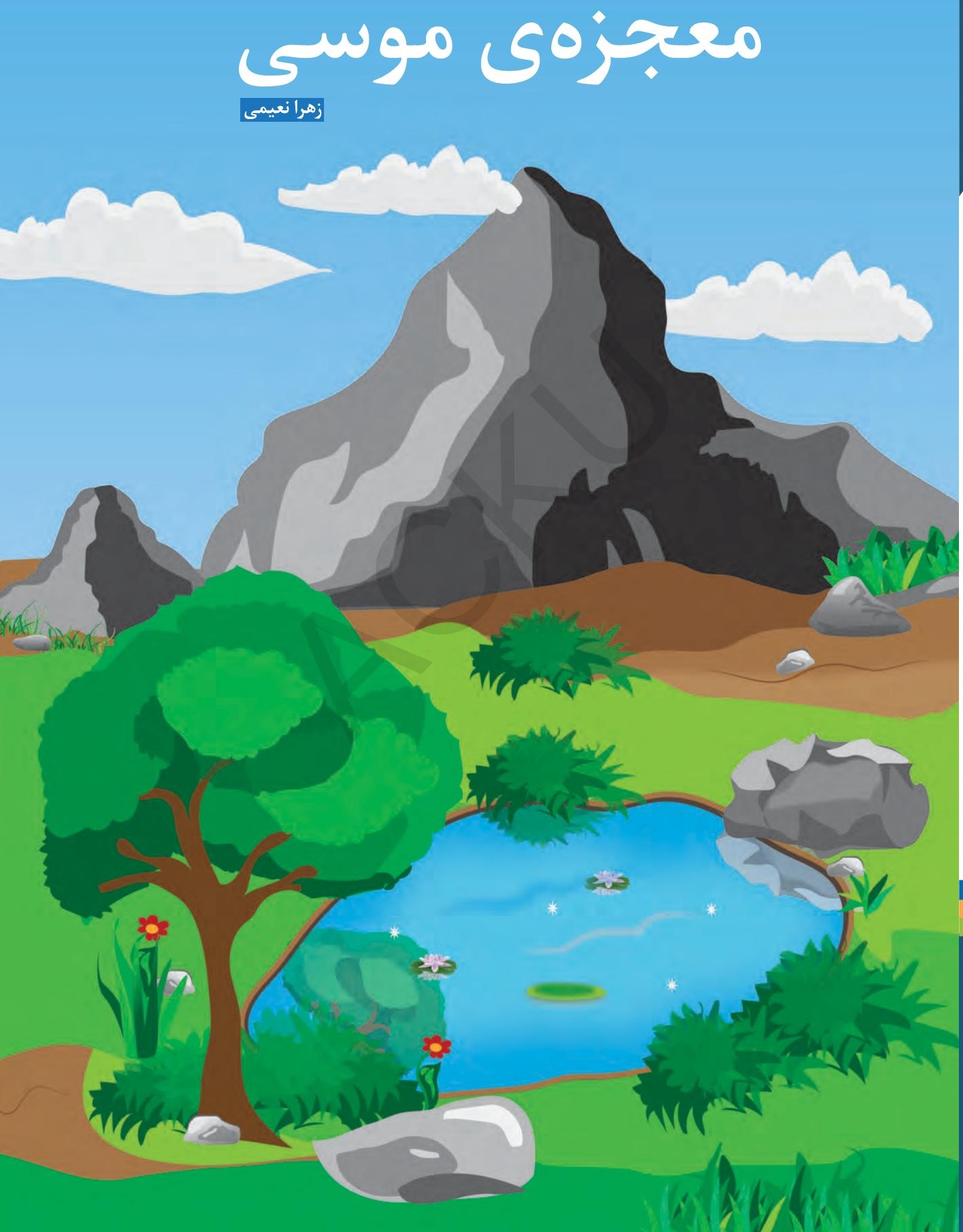


كزيدهى نخستين دور جشنوارهى ادبى رمان كودى و نوجوان د ماشوم او تنكي خؤوان د ادبي جشنواري لوني لومرنه تاكنه
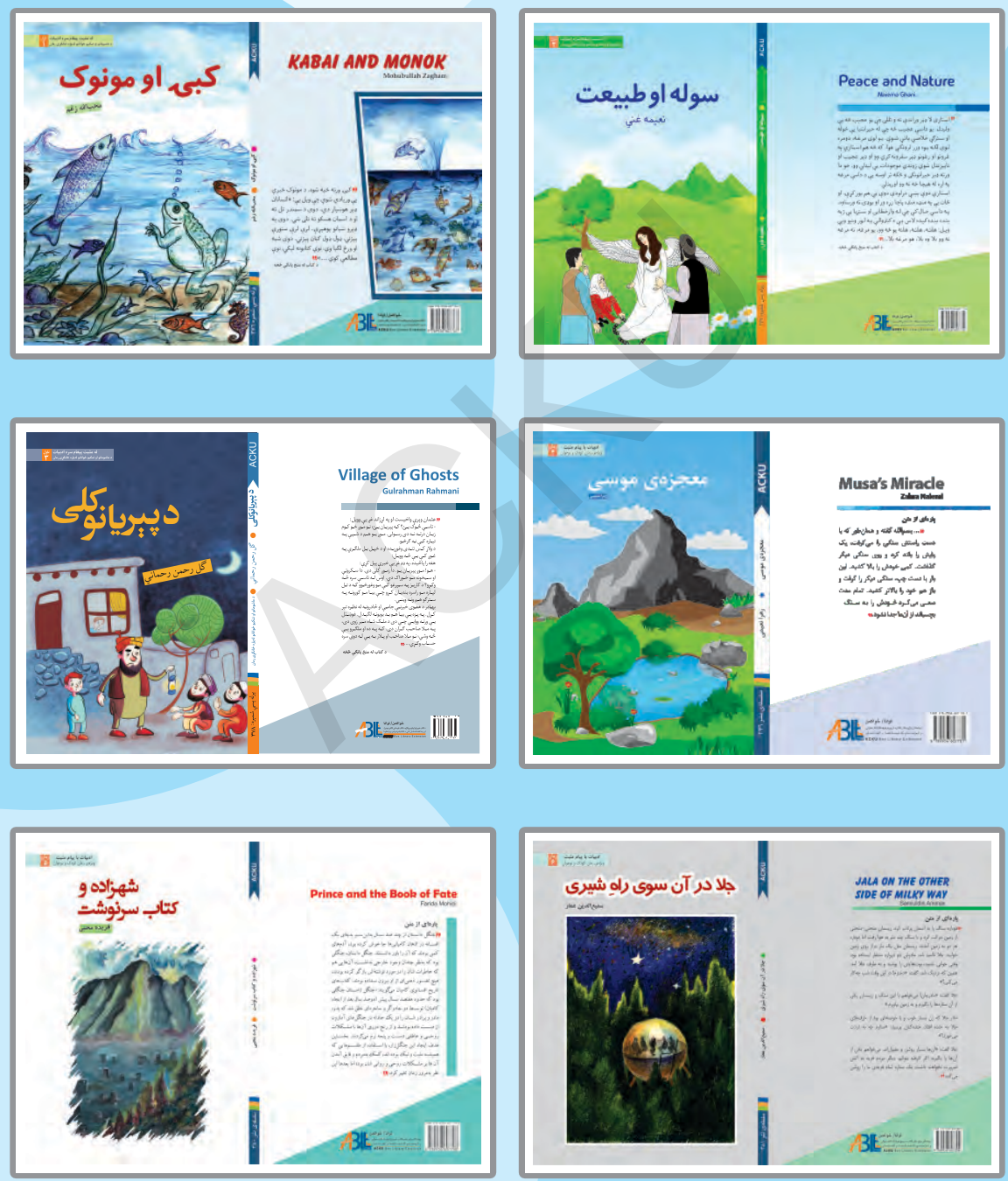
به نام خداوند بخشايندهى مهربان

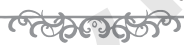




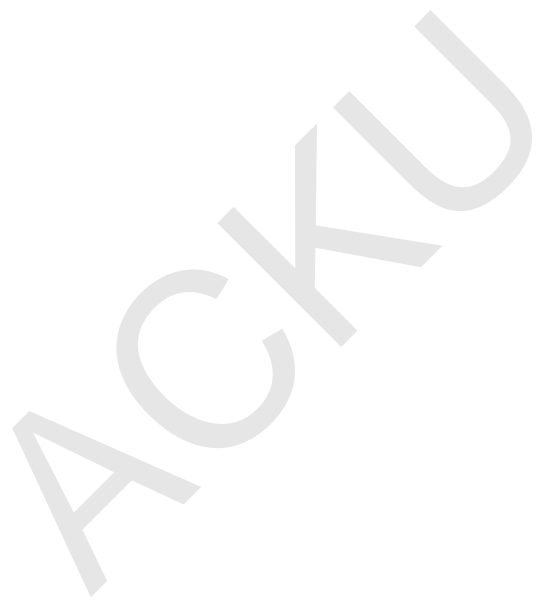


معجزمى موسى زمرا

زهرا نعيمى 


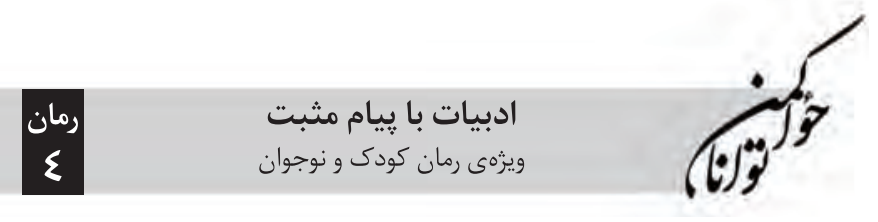

شناسنامهى كتاب

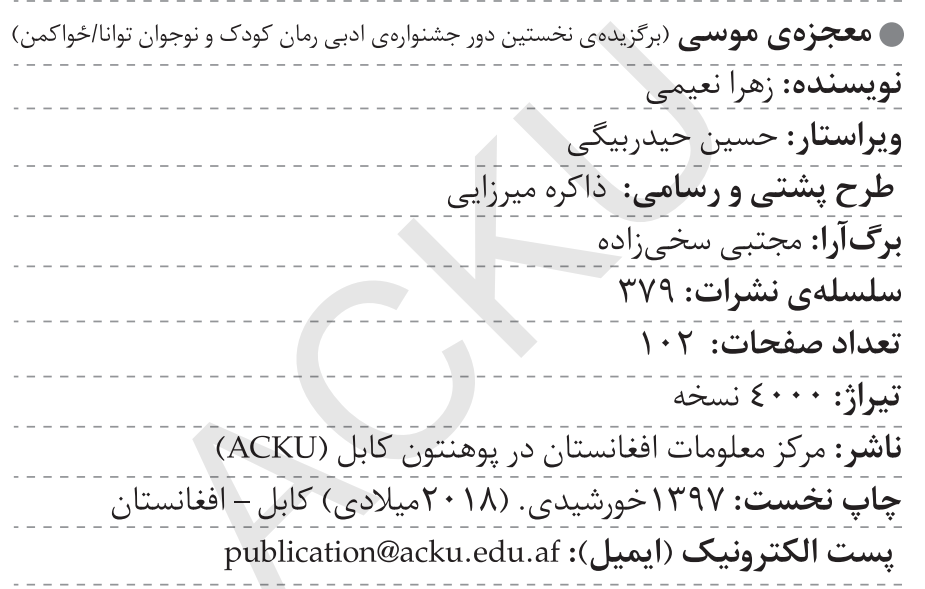

وبسايت:

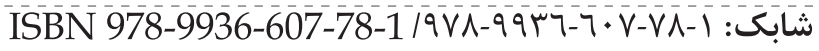

داوران بخش فارسى: محمدحسين محمدى، عزيزالله نهفته و بتول سيدحيدرى

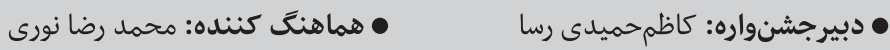

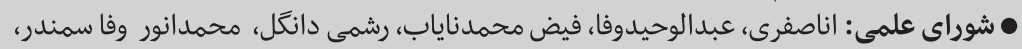

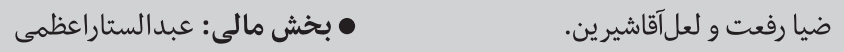

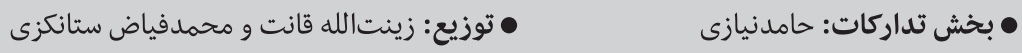




\section{سُخن ناشر}

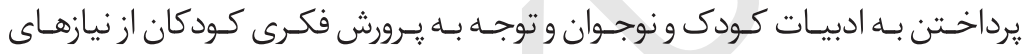

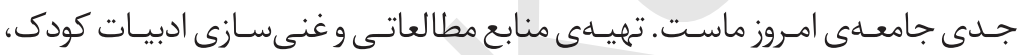

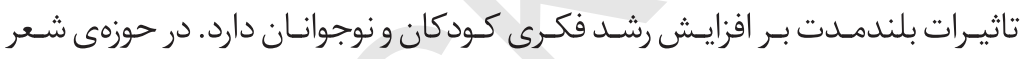

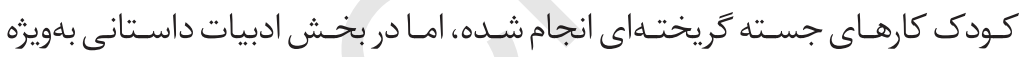

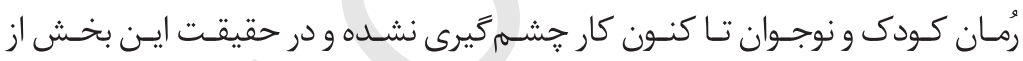

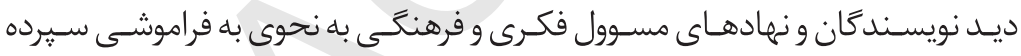

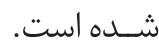

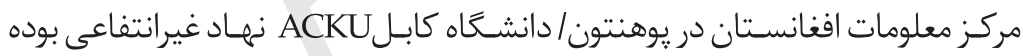

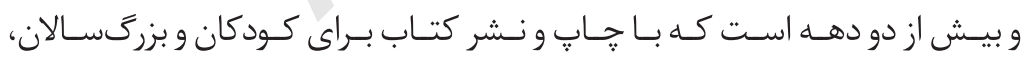

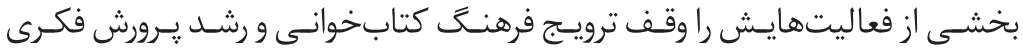

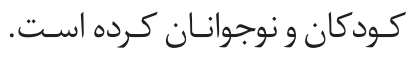

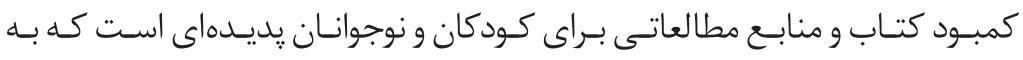

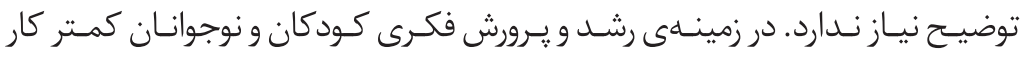

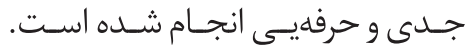

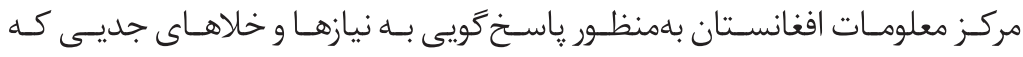

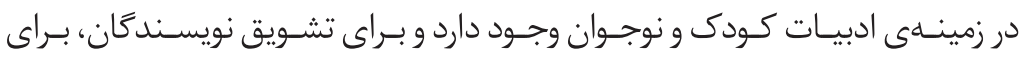

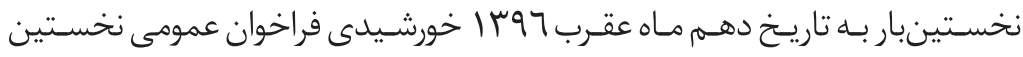

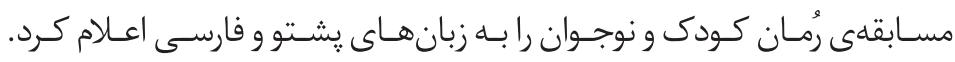




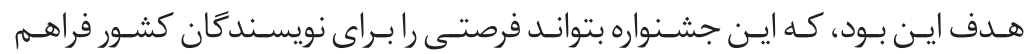

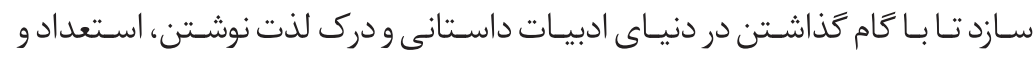

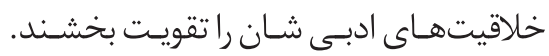

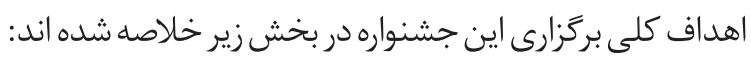

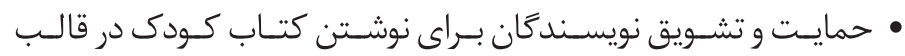

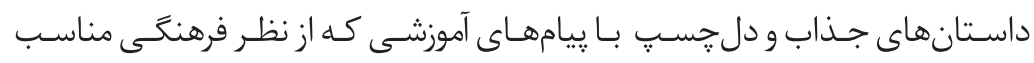

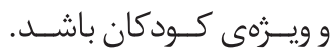

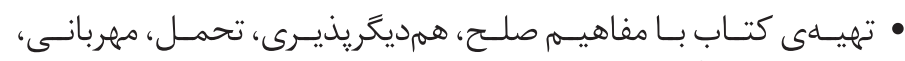

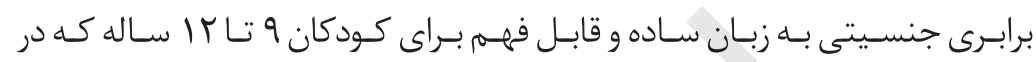

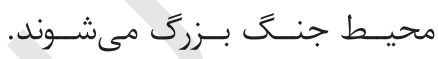

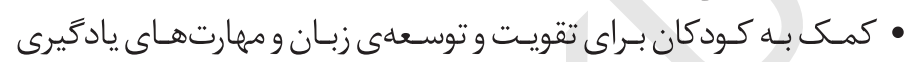

$$
\text { از طريسق خوانـدن. }
$$

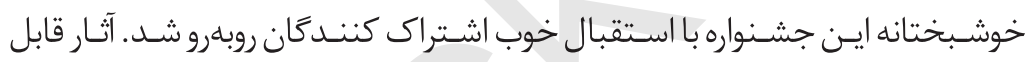

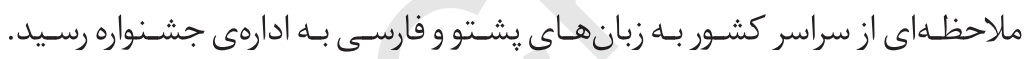

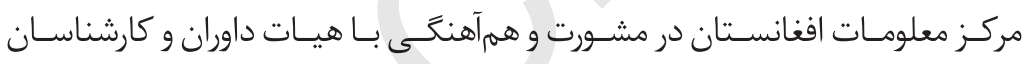

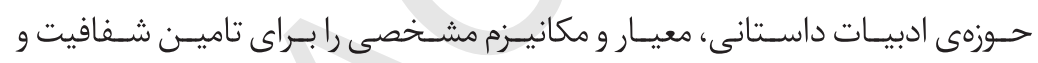

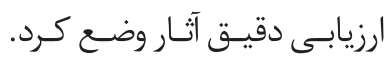

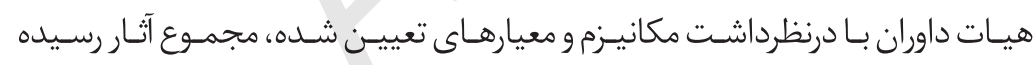

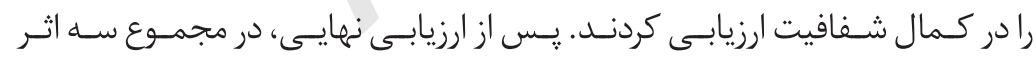

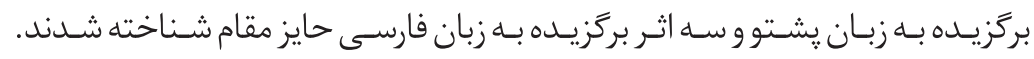

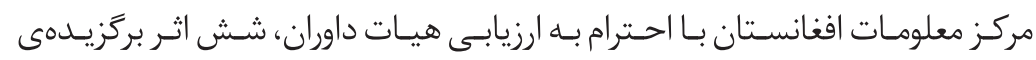

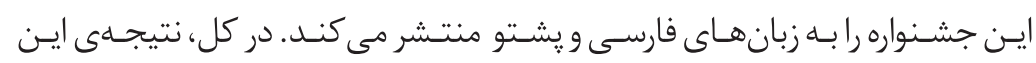

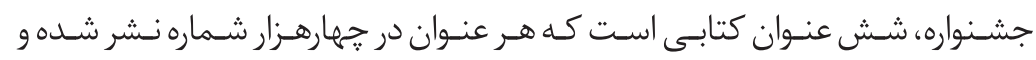

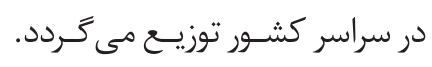

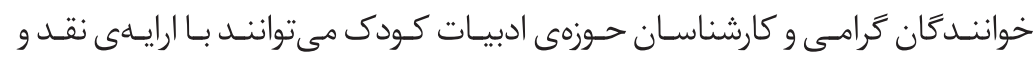

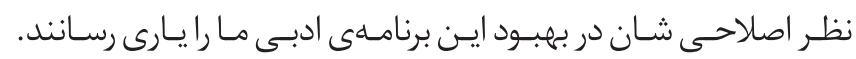


فهرست
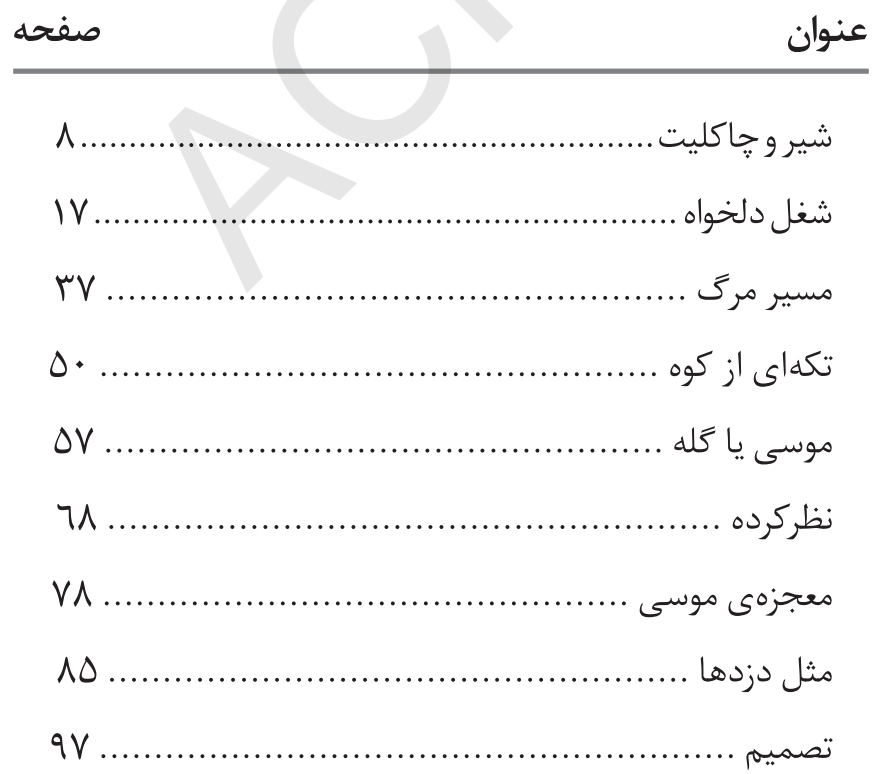


\section{شير و جاكليت}

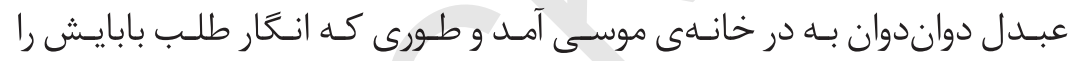
بخواهـد، دودسـتى بـا مشـت بــ دروازه كوبيـد. ـ - موسى، موسى... - ل

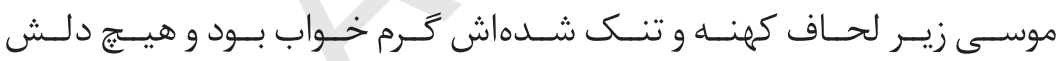

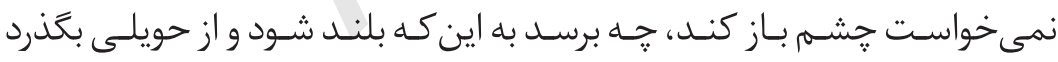

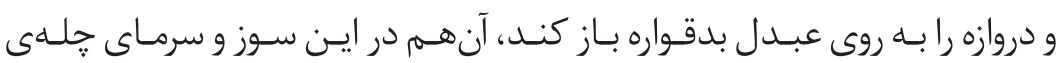

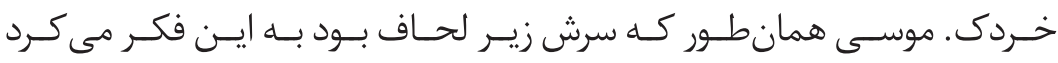

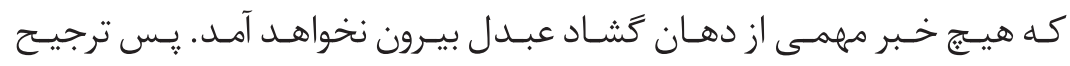

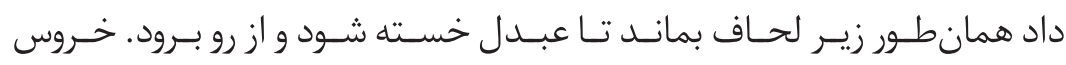

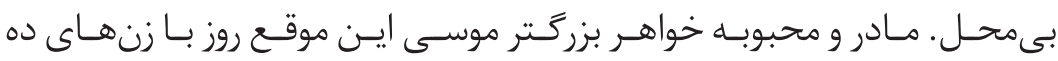

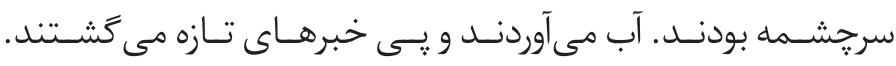




\section{معجزيزى موسى}

عبــل همرجنــان دروازه را مسىزد و اسـم موسـى را فريـاد مي كشـيد. موسـى بـهـ

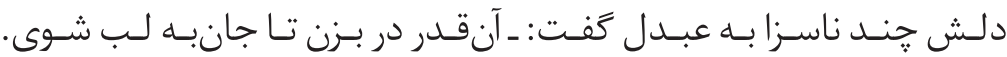

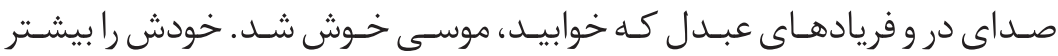

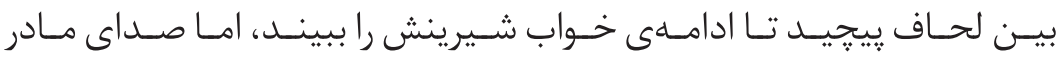
توجهمش را جلب كرد: - جى گی است عبدل؟ جه خبر شده؟ ـ موسى را كار دارم خديجه خاتون. - جه كار است؟ به من بكَو. مادرش هستم، ها.

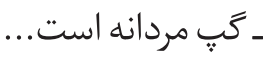

موسى زير لحاف يهلوبهيهلو شد و در دل كفت: (الى دروغ، تو مردى مخم.")

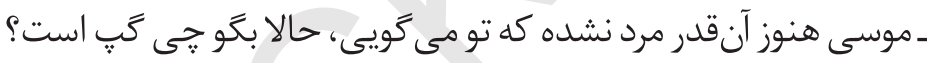

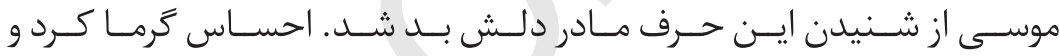
كونههايـش گل انداخـت. از زيـر لحـاف هـم ميىتوانسـت يوزخنـد را روى دهـان

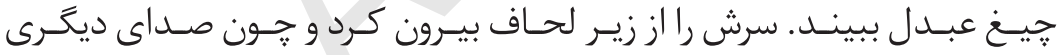

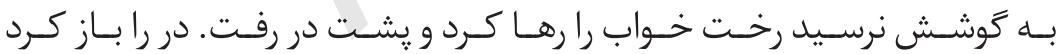
طلبكارانسه از عبـدل يرسـيد: - جه مى خواهى؟

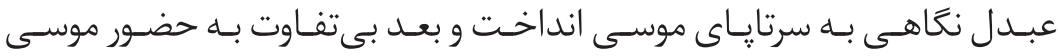
رو كـرد بـه خديجـه خاتـون و كفـت

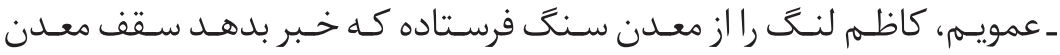
ريـزش كرده و محسـن خـان زيـر آوار مانـده... 
ظرفهـاى شسـته شـده از دسـتان محبوبـه روى زميـن خاكى سـقوط كردنـد و

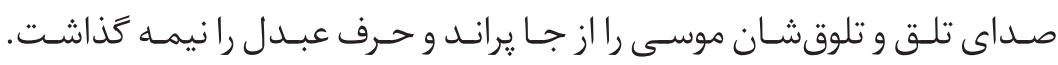
محبوبـه دو دسـتى زد بـه سر و روى خـودش: ـ یدرم، يدرم، و شروع كرد به گريه و زارى.

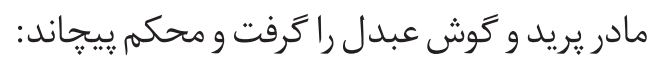

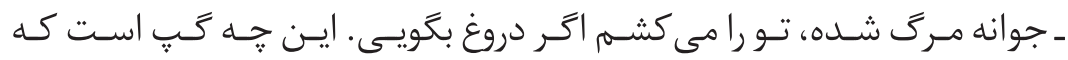

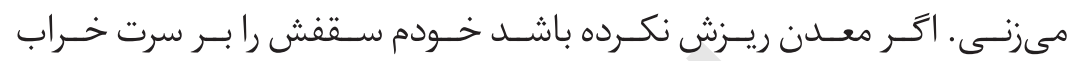

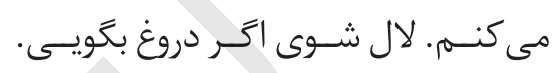
جهرهى عبدل درهم رفت، سرخ شد و اشك به جشمه هايش جمع شد:

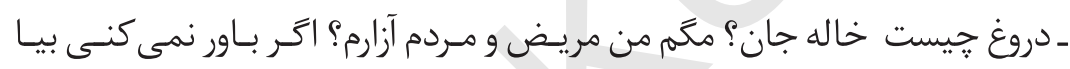

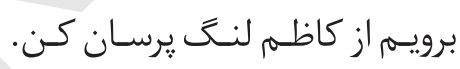
ـ مى آيم، مى آيم. اخر دروغ باشد من مى دانم و تو.

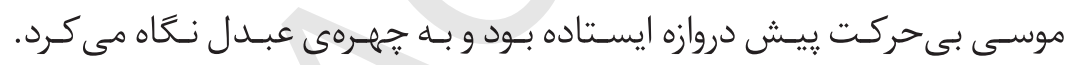

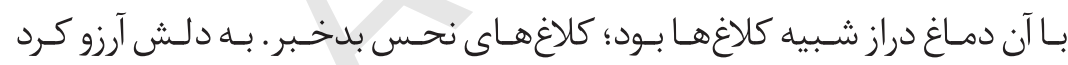

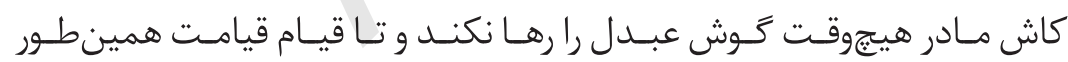

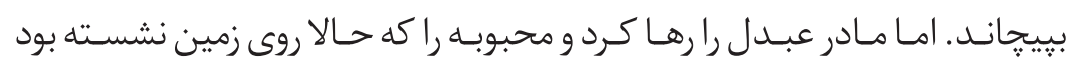
بــه كريـه وزارى، بلنـد كرد:

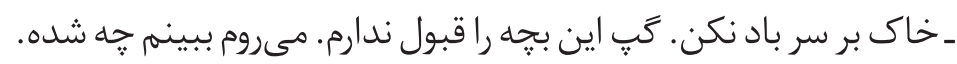
بعد دست عبدل را كشيد و به سمت خانه آنها به راه افتاد. 


\section{معجزمى موسى}

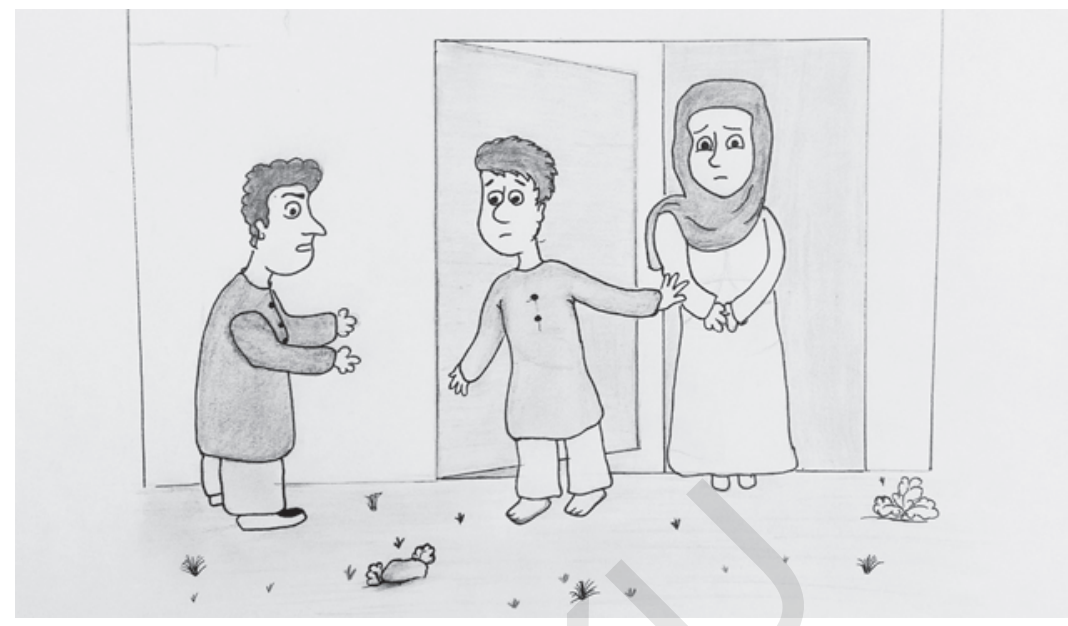

محبوبـه دماغش را بـالا كشــــد وظرفهـاى كلـى شـده را از روى زميـن برداشـت

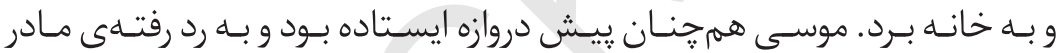

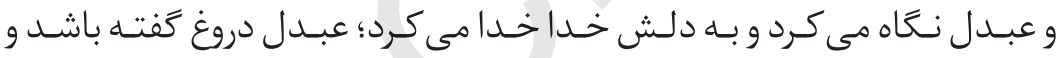

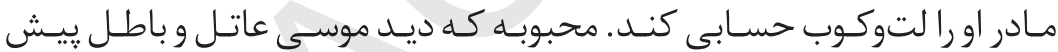

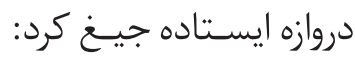
ـيا بيا داخل يا برو دنبال شان ببين جه خبر شده، زود شو.

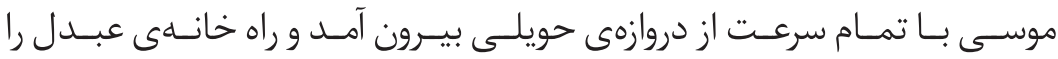

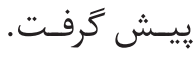

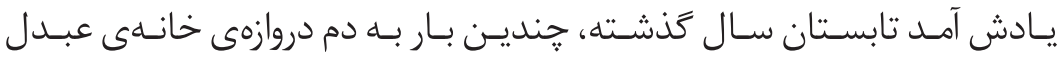

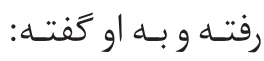
ـ سقف معدن ريزش كرده و اكبر زائر باباى عبدل زير آوار شده.

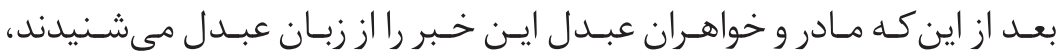


بـهـ سر و روى خودشـان مىزدنـــ. دواندوان خودشـان را بـه معـدن مىرسـاندند

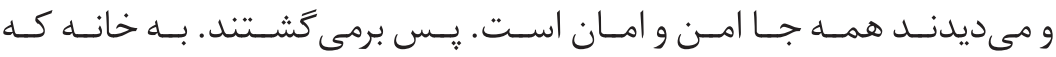
مىرسـيدند نصـف روزشـان كذشـته بـود و عبـدل را مـورد لتوكـوب جانانـه قـرار

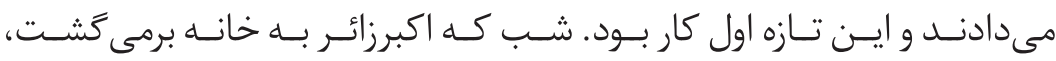

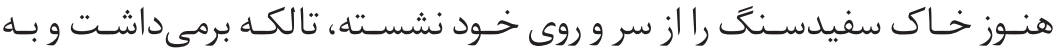

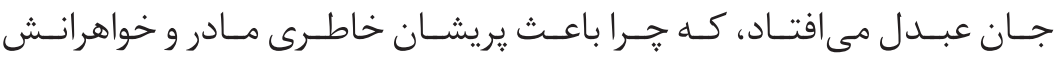
شـده اسـت. عبــل از خاطـر دروغهـــ موسـى دوبـار لتوكـوب جانانـهاى نـوش

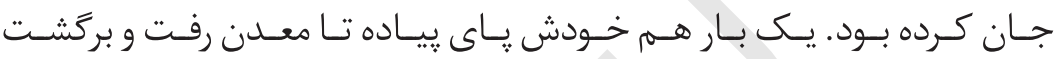

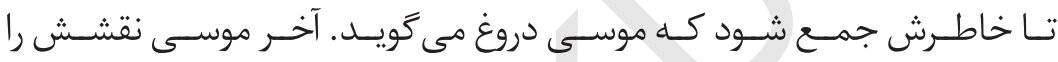

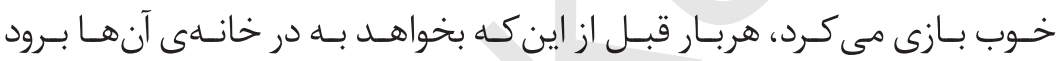

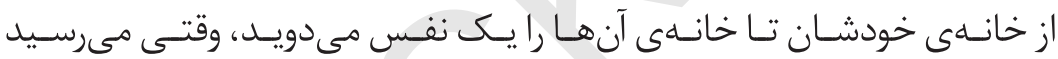

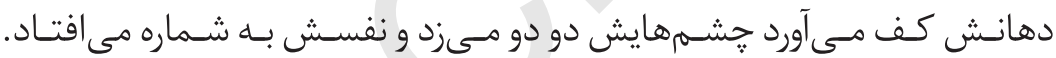

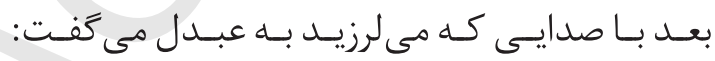

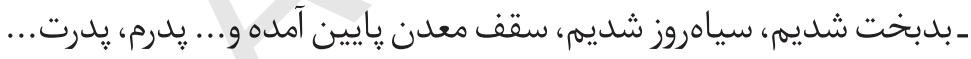

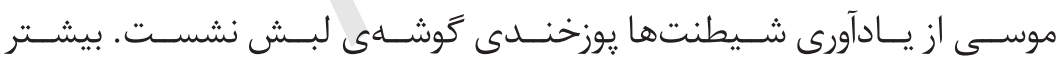

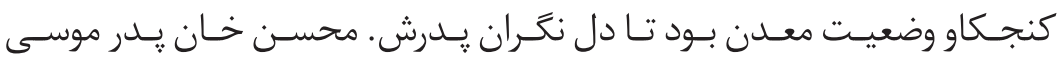
زمانسى سردار جنـَ بـود. از نظـر موسـى كسـى كـه از جنـعَ جـان سـالم بـه در

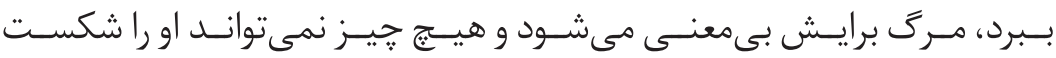

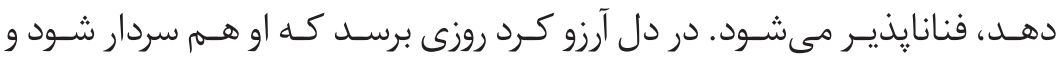

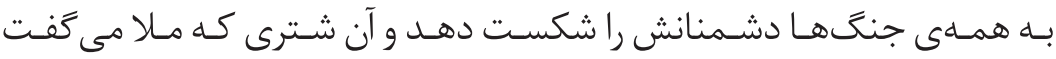
نامـش مـرى اسـت و در خانسهى همــه مـى خوابـد، جـرأت نزديـك شـدن بــه در 
خانـهى او را يـيـدا نكنـد. موسـى در هميـن فكرهـا شمشـير خيالـى اش را از غــلاف كمربنـــش بيـرون

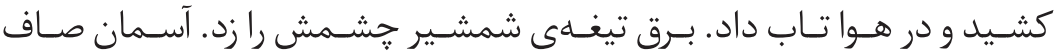
بـود و خورشـيد مى درخشـيد. هــوا هنــوز سرد بـود و بـرف زيــر درختـان و كنــار

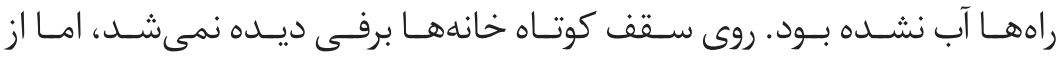

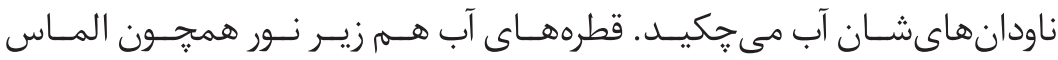

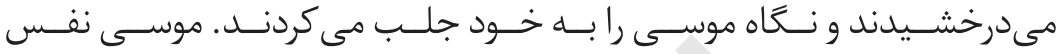

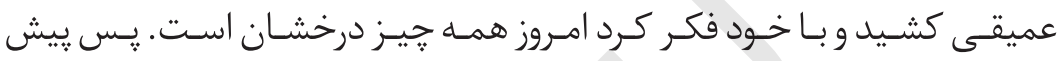
بــه سـوى ماجرايسى تـازه. همـه جـا سـاكت بـود و فقـط صــاى عرعر خـر كربلايى

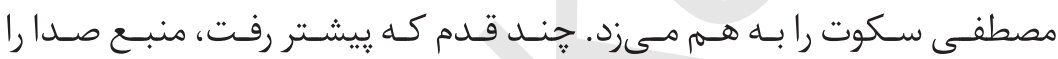

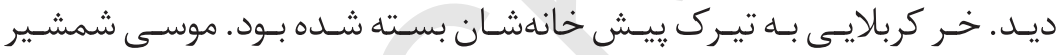

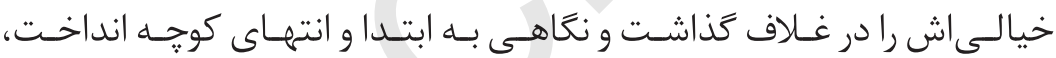
كسـى رانديـد. آرام افسـار خــر را بـاز كـرد و حيـوان را بـهـ دنبـال خـود كشـيد. كمسى كـه از خانـه كربلايسى مصطفى دور شـد، سـوار بـر خر بـه سـمت زمينهاى كشـاورزى هـى كـرد. زمينهــاى كشـاورزى زيــر بـرف مدفــون بودنـد، ســيد، يكـدست. موسـى نشسـته بـر خـر، جرخـى زد و سـياه دشـمن را در مقابـل خـود

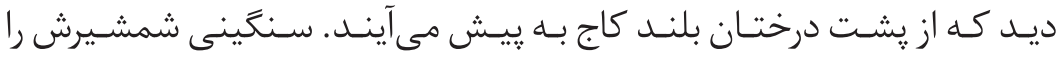

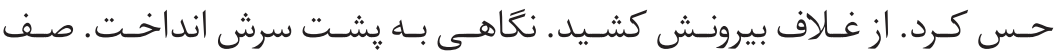
سربـازان در لباس هـاى يـك شـكل و آمـاده بـراى حملـه را ديــــ شمشـيرش را بــه سـمت آسـمان بـرد و دسـتور حملـه رافيـاد زد. .... 


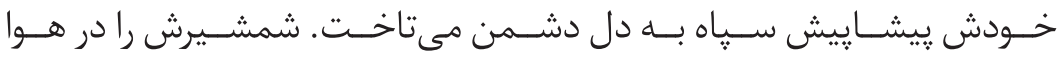

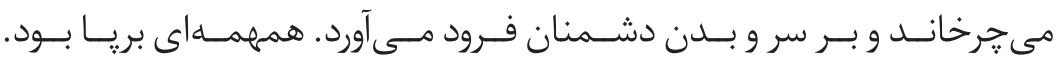

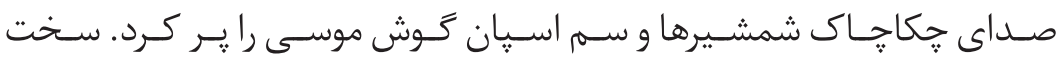

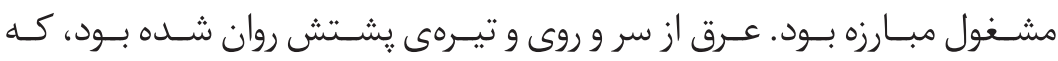

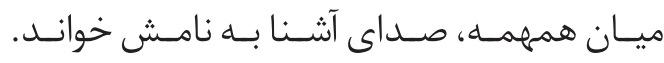
ـ موسى، موسى. محمـد، دوسـت و همبـازى موسـى بـود. هميشـهـ مى دانسـت كجـا بايـد موسـى را

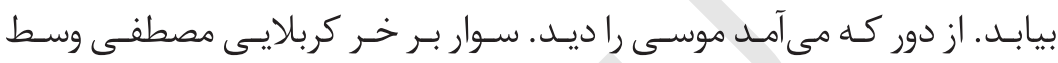

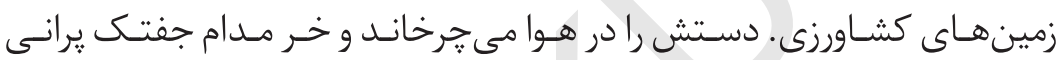
مى كنـد. يـا تيـز كـرد و از هـمان فاصلهـى دور جيـغ كرد:

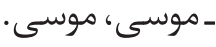
موسـى از كشـتن دشـمنانش دسـت كشـيد. همـهـى سربـازان و سـياهيان در

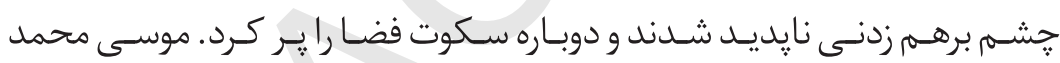

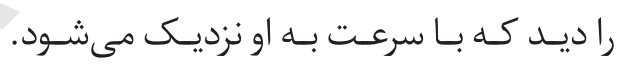
ـ موسـى، موسـى. همــه جـا را بـه دنبالت كشـتم. كجايسى تـو؟ همـهى اهل محل بــه خانـهى شـما جمـع شـدهاند. موسى كه به خودش آمده بود پيرسيد:

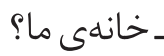

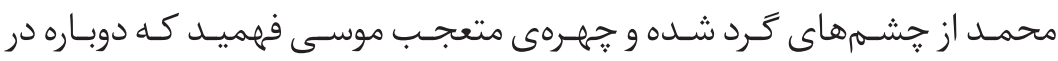

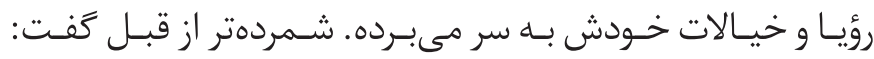
ـ ها، به خانهى شما، يدرت را آوردهاند. 


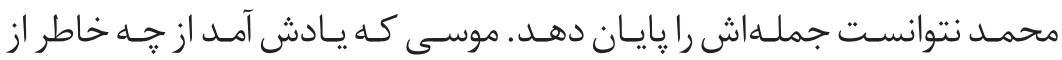

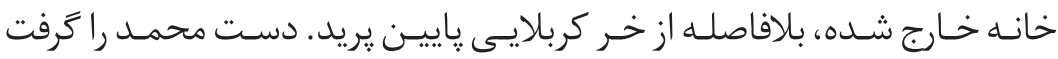

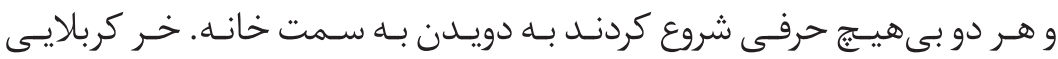

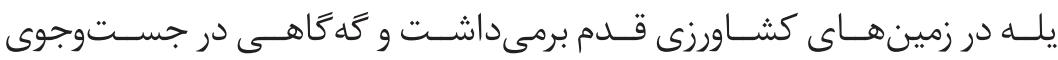
علـف يـوزهاش را بـهـ برفهـا مي كشـيد.

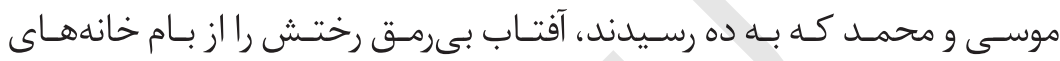
كاهگلسى كشـيده بـود و مىرفت تـا يشـت كوههـا ينهـان شـود. آسـمان نارنجـى

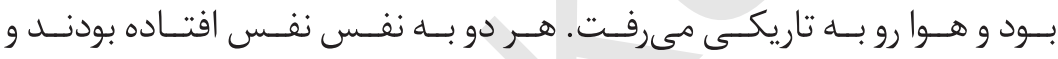

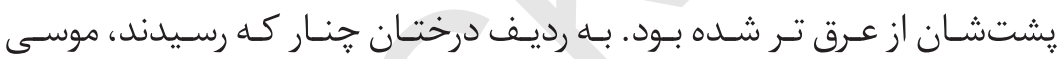

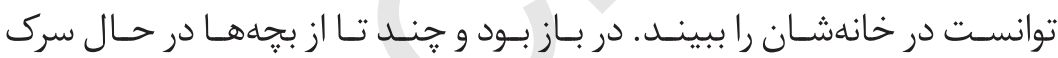

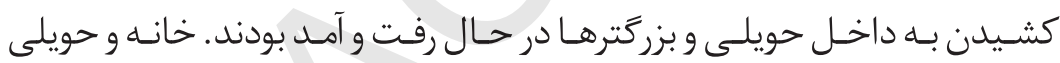

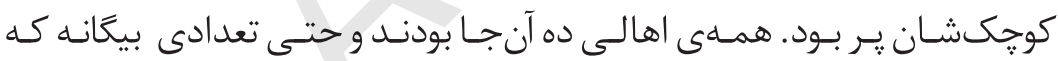

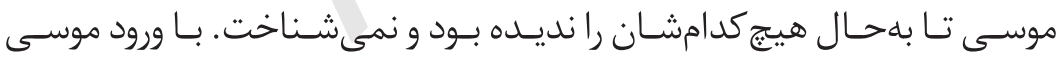

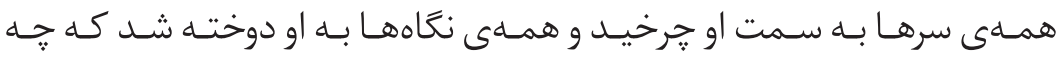

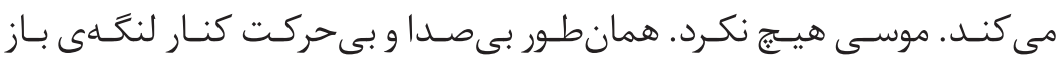
در ايسـتاد و زيرجشـــى بــه مـادر و خواهـر بزركـترش محبوبـهـ نـعاه كرد. مـادر و

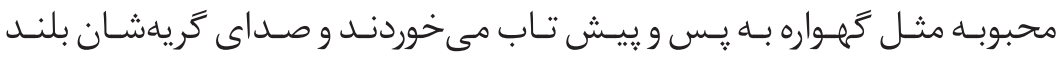

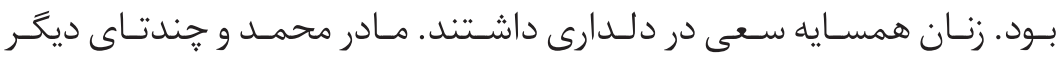

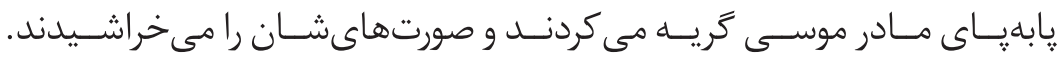




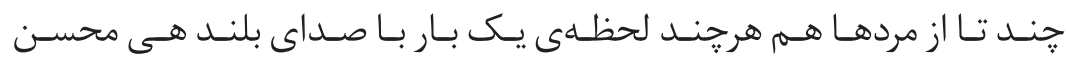

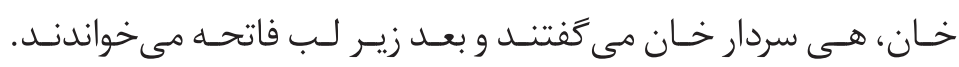
ـ هى محسن خان. ـ خدا رحمتت كند مرد. - نور به قبرت ببارد.

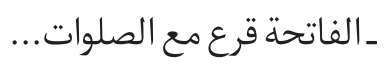

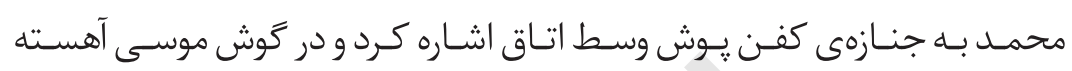
كفت :

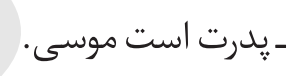

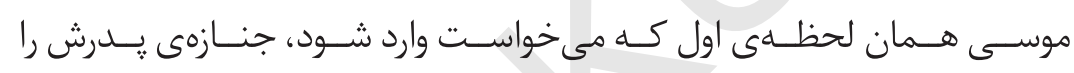

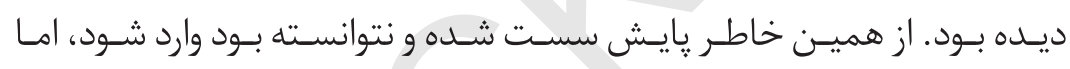

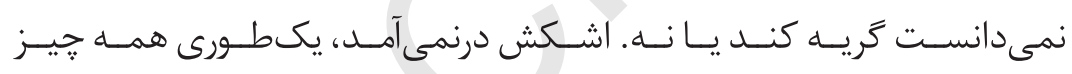

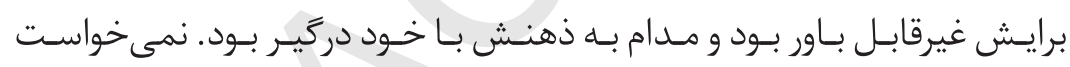

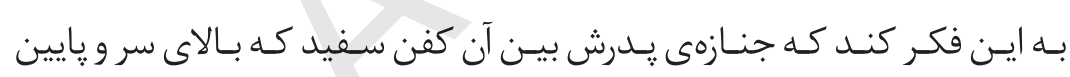

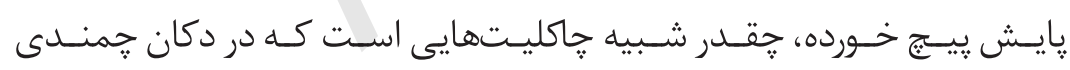

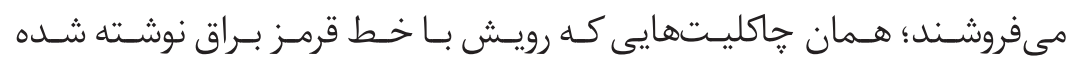
بـود شـير و جاكليت. 


\section{شغل دلخواه}

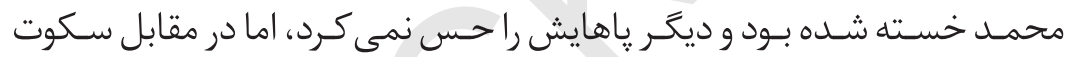

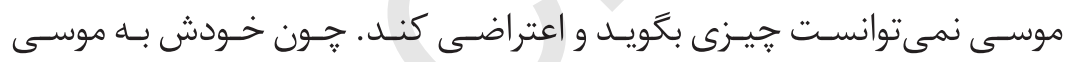

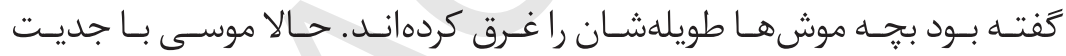

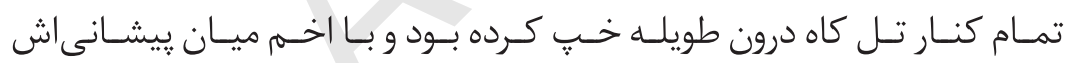

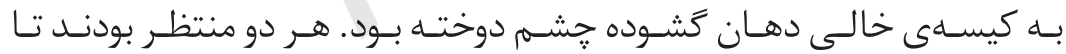

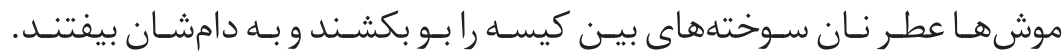
محمـد طاقتش تمـام شـد و بـا صـداى آهسـته بـهـ موسـى كفـت

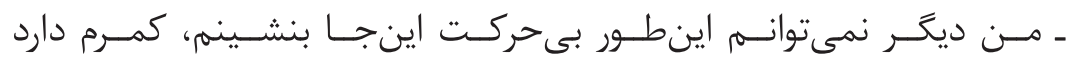

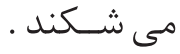
موسى بدون جشم برداشتن از كيسهى خالى، آرام جواب داد: ـتا بيست به دلت بشمار، اگر خبرى نشد، مىرويم. 
محمد اوف كشيد و بى صبرانه كَت: - بيست زياد است.

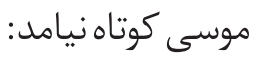
- نوز0ده. ـ اوووه... اخر شمرده بودم تا حال ده تايش كم شده بود. - يس ساكت باش و بشمار.

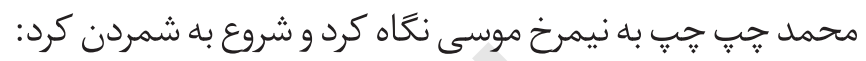
- يك، دو، سه، جهار، ينج، شش، هفت.

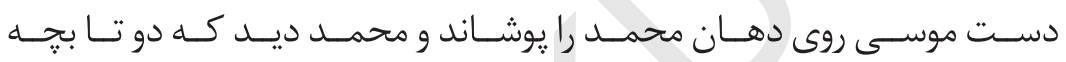

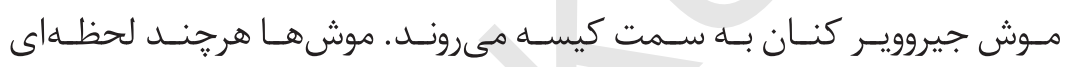

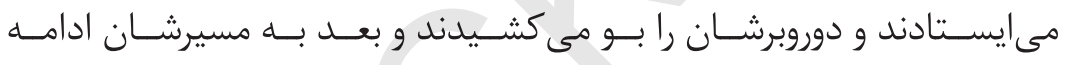

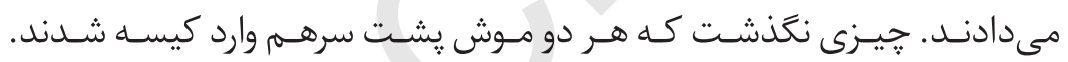

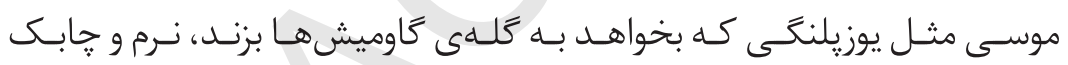

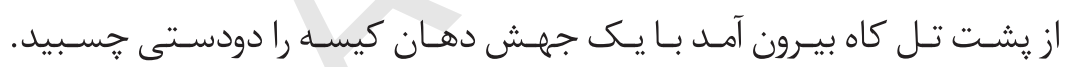
خنـدهى شـيطانى سرداد و كفـت: ـ حالا مى توانى بلند شوى.

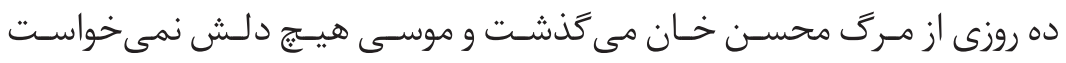

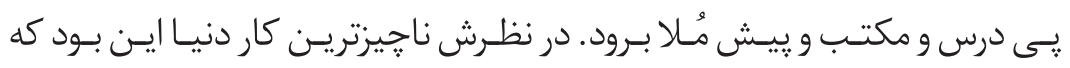

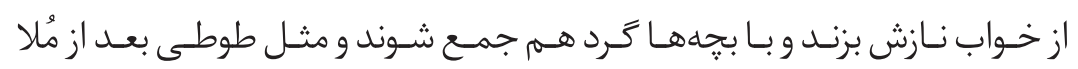

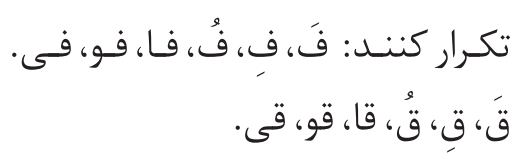




\section{معجزم موسى}

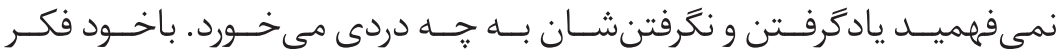

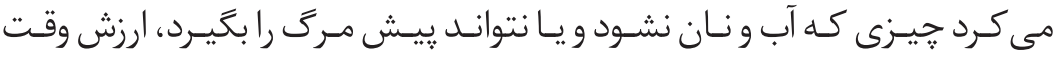
كذاشـتن نـدارد و هـر ثانيـهاى كـه بـراى آن وقت بخَذارى يعنى عمـرت را تلـف

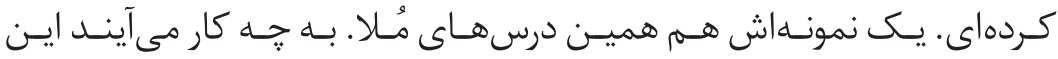
فَ، ف، فُ، فـا، فـو، فـى ؟ امـا حـالا بـى صبرانـه منتظـر فـردا بـود كـه بـه مكتـب بـرود و يــى درس مُـلا بنشـيند. با خوشحالى به محمد كفت: ـصبح زودتر بيا دنبالم. مكتبمان دير نشود. خدا نگمهدار.

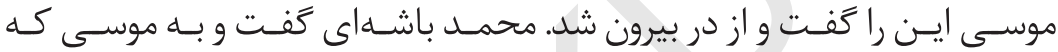
كيسـه بـه دسـت بـا عجلـه دور ميىشـد جشـهم دوخـت. صبـح روز بعـد برخـلاف هميشـه، اينبـار موسـى جـزو كسـانى بـود كـه زودتـر از مُـلا مـىرسـيدند. وقتى به مكتب رسـيدند موسـى جايسى نزديـك دروازه، جهارزانو نشسـت و بعـد از جـا دادن كيسـه زيــر يايسش، كتـاب كنـده يـارهاش را بـاز كـرد و نگًاهـش را بـه خطهـاى كتـاب دوخـت. عبـدل كـه هميشـه بـه دنبـال خـراب كردن موسـى بـود، بـا صـداى بلنــد كفتـ: ـ خورشيد از كدام طرف درآمده موسى خان؟ صنف درس را منور كرديد. موسى حتى جشمه هايش را از كتاب برنداشت و در همان حال كه بود كفت: - از يشت خانهى طاهره جان.

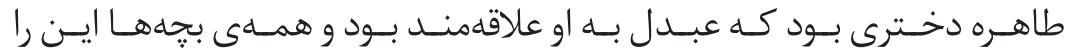
مى دانسـتند. بـا شـنيدن ايسن جملـه قهقهـه و هرهـر بجههــا در و ديـوار صنـف

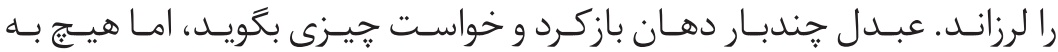




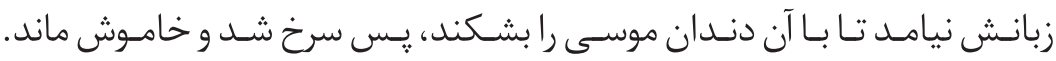

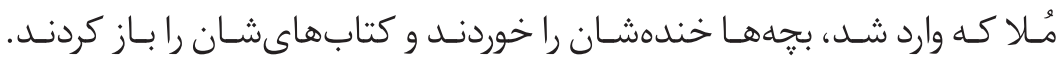

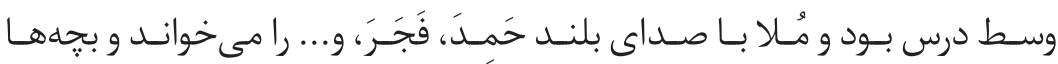

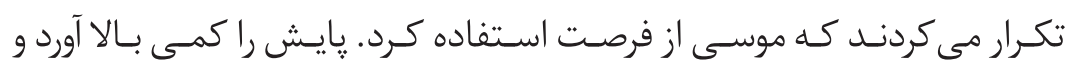

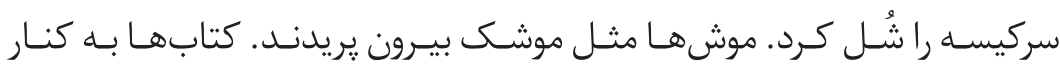

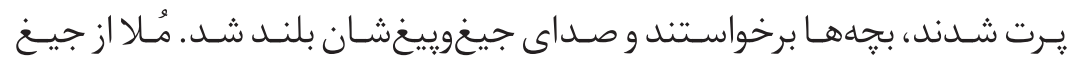

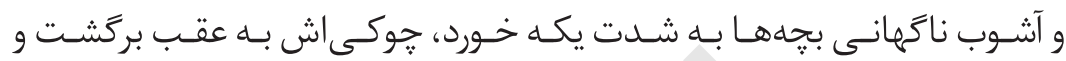

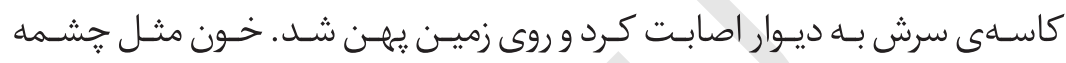

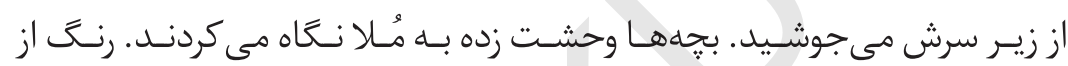
كُخ موسـى يريـد. آب دهانسش راقـورت داد. تنهــا كارى كـه بـه ذهنـش رسـيد فرار

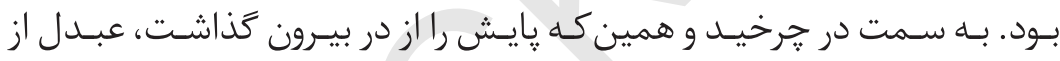

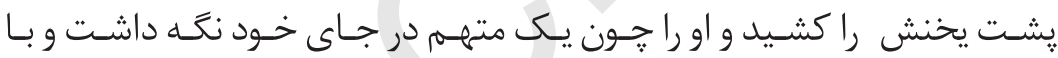
لحنسى كينهتوزانـه كفـت ـ كجـا بخيــر موسـى خـان؟ طلـوع خورشـيد راكـه ديـدى، حـالا غروبـش را هـم نظساره كن. محمد زودتر از ساير بجهها به خود آمد و فرياد زد: ـ طبيب، بايد طبيب راخبر كنيم. اين راعفت واز بيرون يريد.

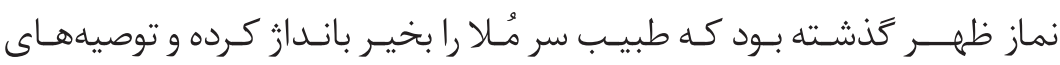

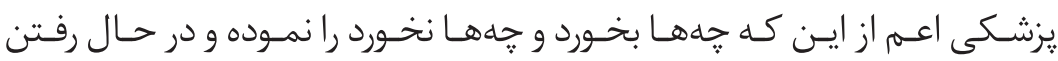

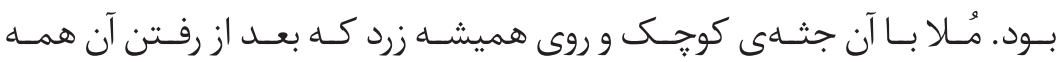




\section{معجزئى موسى}

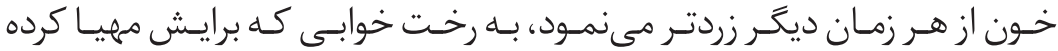
بودنـد، دراز بــه دراز افتـاده بـود، آه و نالـهاش يـكـ لحظـه هـم قطــع نمى شـد.

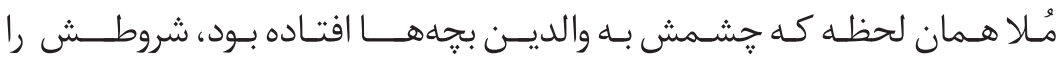

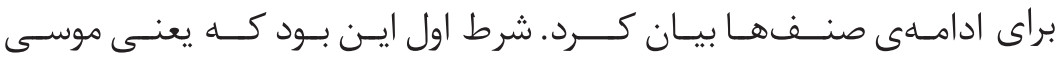
ديخـر حـق نـدارد يايسش را در صنـف درس او بَـذارد و شرط دوم ايـن كـه هريـك از بجهههـا كـه مـى خواهـد در صنفـهـاى او حـاضر شـود ماهيانـه زجيـزى برايـش بيـاورد. والديـن بجههــا كـه احسـاس مى كردنـد فرزنـدان آنهـا هـم بـى تقصيـر نيسـتند، شرط مـلا را بـراى ادامـهى صنفهــا يذيرفتنـد و حــال هركـدام يـك ظـرف روغـن زرد، شـانة تخـم مـرغ و يـا ظـرف شـير و يـا جنـد قـرص نـان و...

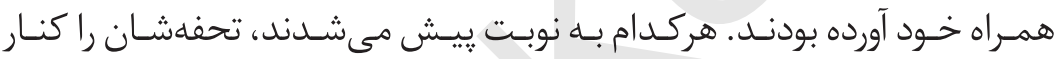

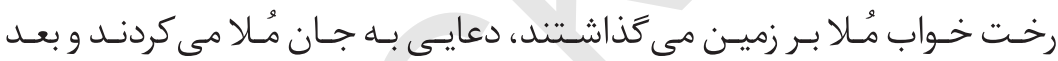

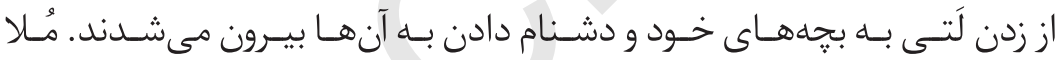

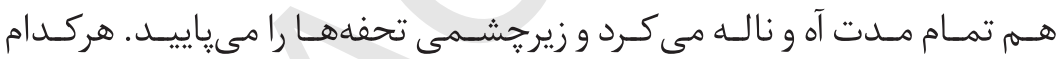

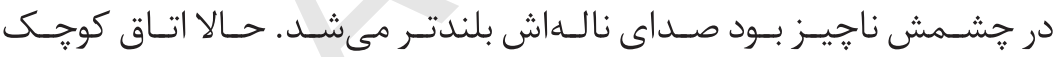
مُعلا كـه در آن فقـط يـك قالين، تعـدادى رخـت خـواب كـه روى هـم جيــه شـده

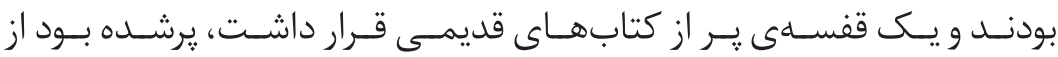
تحفههــاى اهالـى روسـتا. موسـى يشـت در اتـاق كنـار مـادرش ايسـتاده بـود و بــه دشـنامهاى مـادر تَوش مـى داد. مـادر بـا صـداى آهسـته هرجنـد لحظـهى

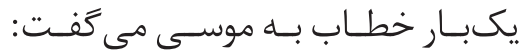

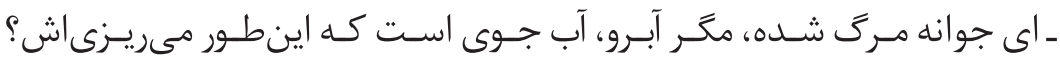

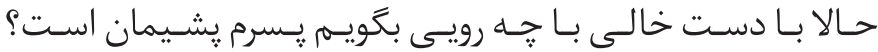




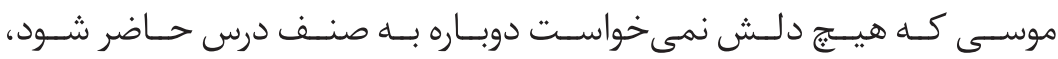
بلافاصلـه جــــواب داد:

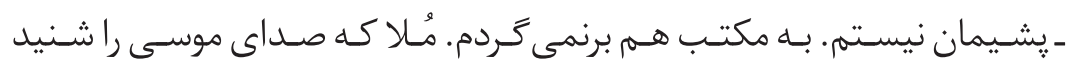
ناله و فغانسش بلنـد شـد و فريـاد زد:

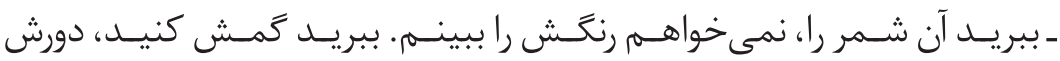
كنيـد.

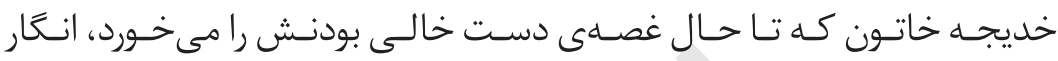

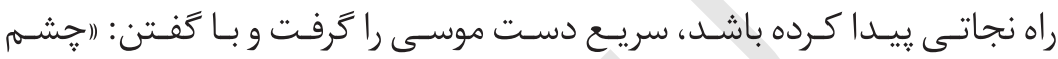

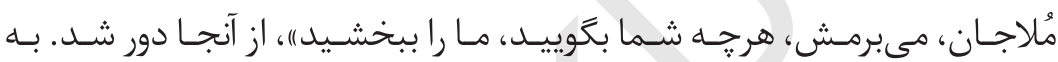

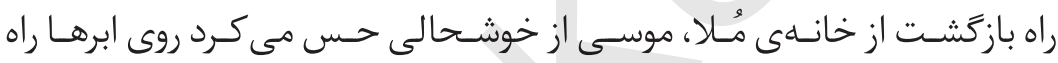
مسىرود. بـراى اين كـه مطمـئن شـود جنـديـن بـار از مـادرش تيرسـيد: - يعنى ديخر هيج وقت نمسىروم ييش مُلاتا درس ياد بخيرم؟ خديجه خاتون هربار با عصبانيت بيشتر جواب مى - باشه كارى كه كردماى نه.

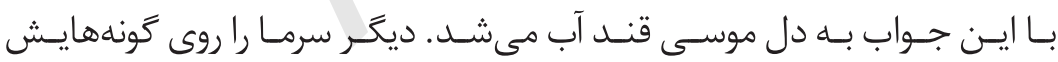

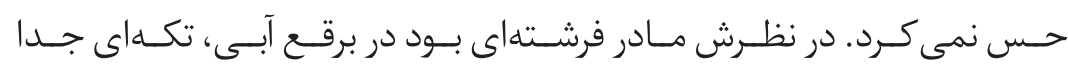

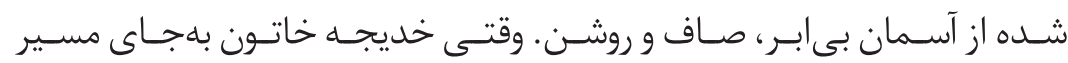

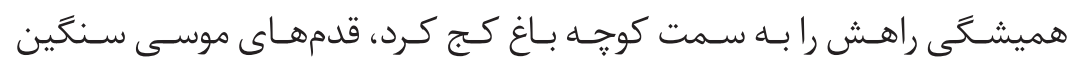

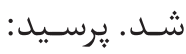

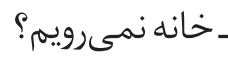

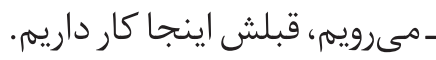




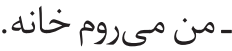
ـ نه، تو بامن مى آيى، با هم مىرويم.

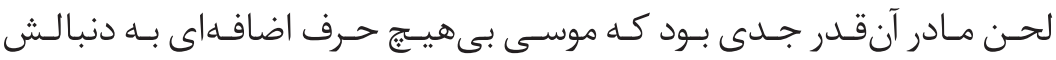

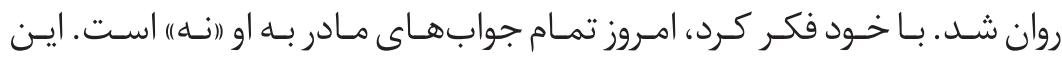

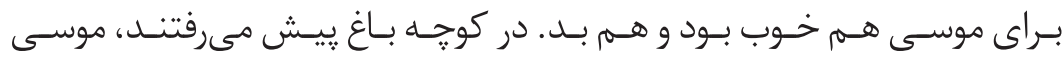

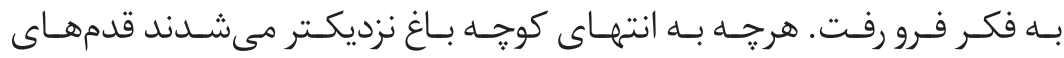
موسـى كندتـر مىشـد.

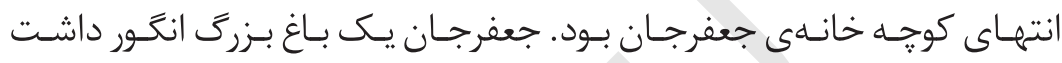
كـه بــه شـش هكتـار مىرسـيد. خانـهاش هـم بيـن هميـن بـاغ بـود. يـك خانـهى

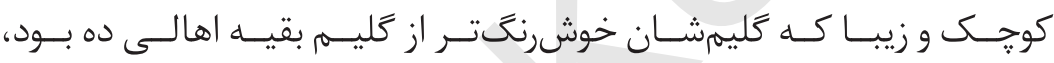

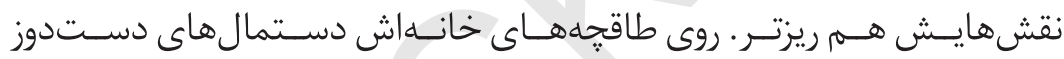

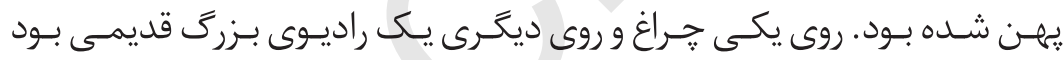

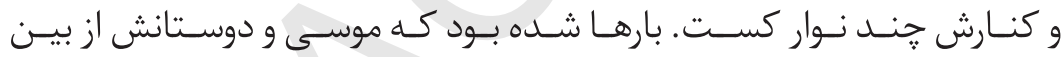

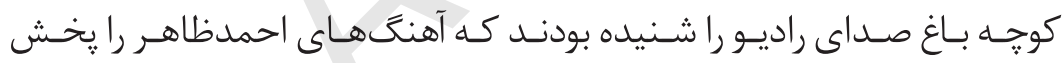

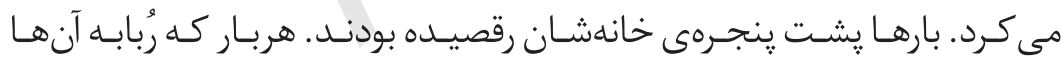
را ديـده بـود صـداى راديـو را بلـندتر كرده بـود و آنهـا بيشـتر رقـص كرده بودنـد.

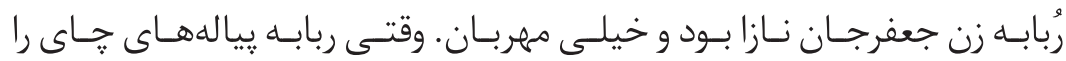
ييـش موسـى و مـادرش كذاشـت، دسـتى بـه سر موسـى كشـيد. موسـى حسـ

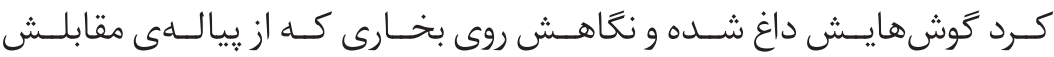

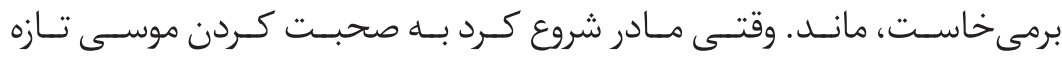

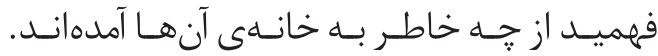




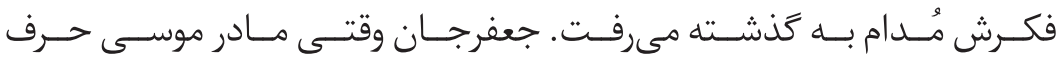

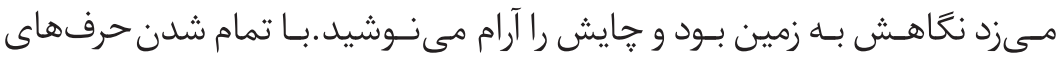

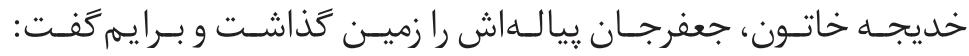

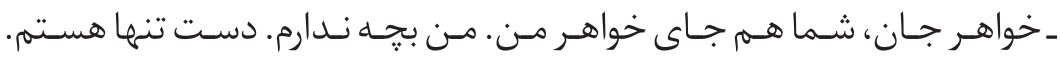

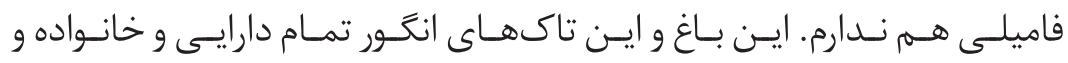
بجه هـاى مسن هسـتند.

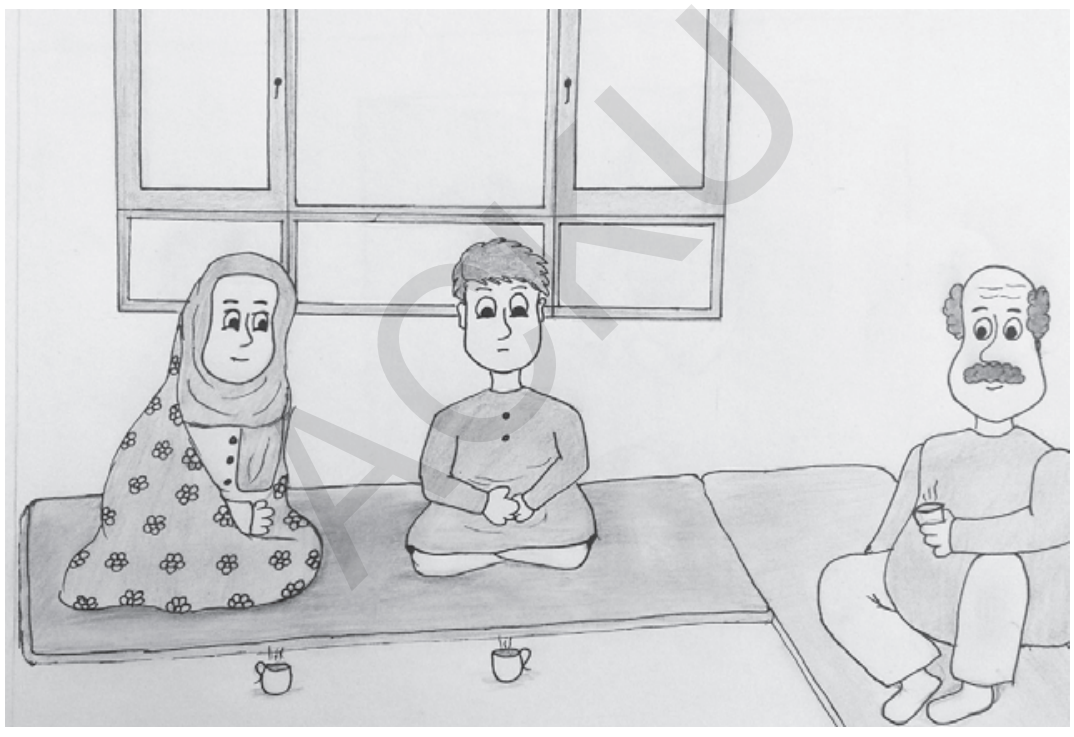

رسـيدكى بـه درختـان ايسن بـاغ تمـام وقـت مـرا يـر كـرده، خــوش مىشـوم يكىى

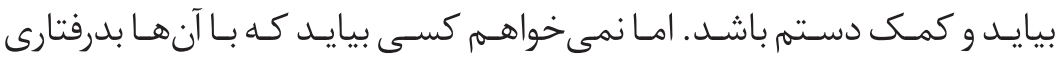

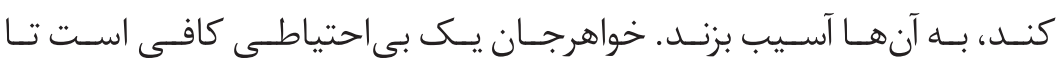
تمـام زحـمات مـن، بجههــــ مـن بسـوزد. خواهـر جـان خـودت كـه تابسـتان را 


\section{معجزئى موسى}

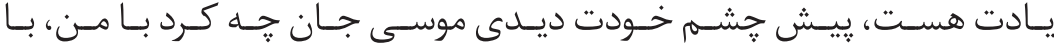
درخت هايسم، بـا بجههايسم.

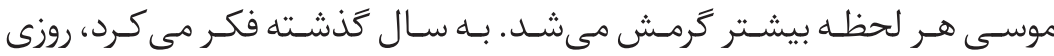

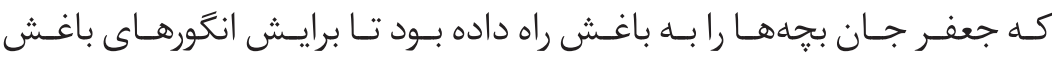

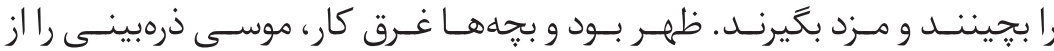
جيبـش درآورد و بـه بجههــا كفــت -براىتان سرگرمى جور كردم.

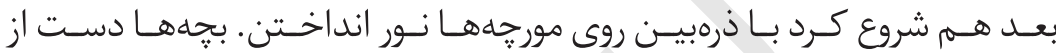
كار كشـيدند و محـو تماشـاى موسـى شــند. موسـى ذرهبيـن را بـا دقت ٍـس

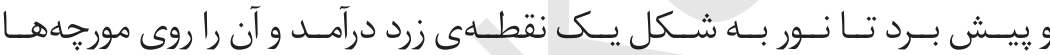

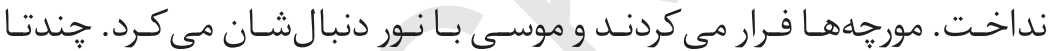

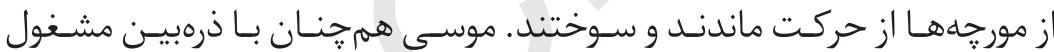

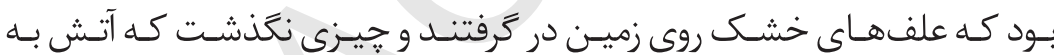
تاكهــاى انتَـور رسـيد. صداى جعفرجان موسى را از فكر بيرون آورد: ـ درست است كه خدا راشكر به موقع رسيدم و آتش را خاموش كردم.

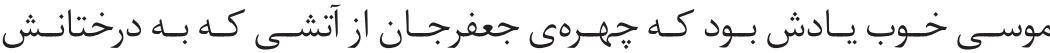

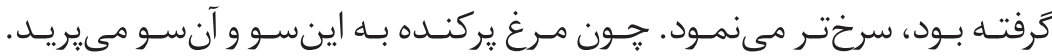

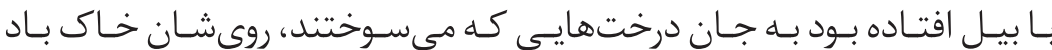

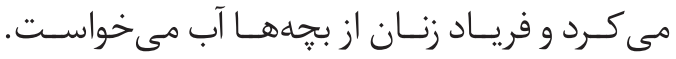
جعفرجان همزجنان حرف مىزد: 
ـ اما جشمم ترسيده خواهر جان. نبايد يك اشتباه را دوبار تكرار كرد. خديجـه خاتـون جايسش راخـورده، نخـورده بلنـد شـد و خداحافظى كـرد. موسىى

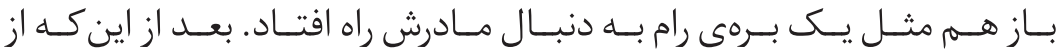
كوجهابـاغ بيـرون آمدنـد، موسـى فهميـد باز هم مسيرشـان به سـمت خانه نيسـت.

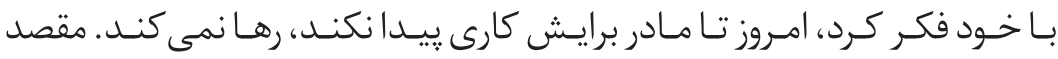

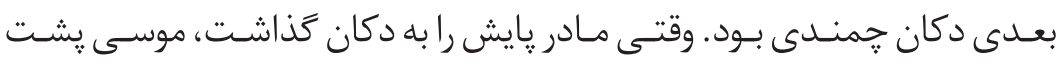

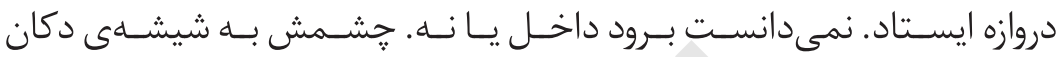

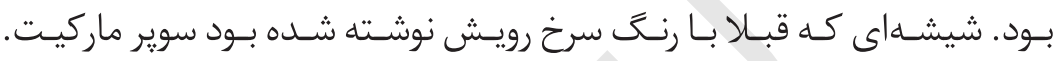

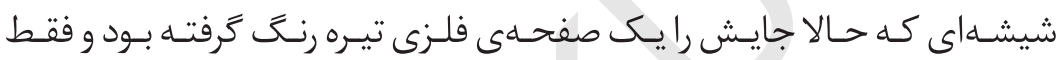

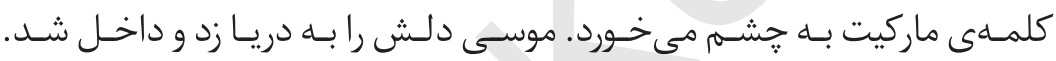

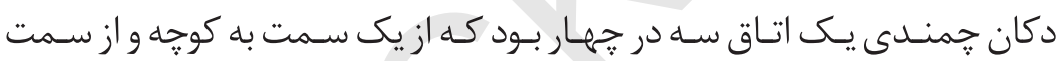
ديخـر بـه خانـهاش راه داشـت. دور تـا دور دكان بوجىهايـى ماش، نخـود و لوبيـا

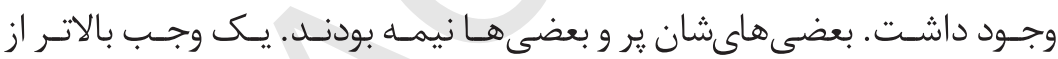

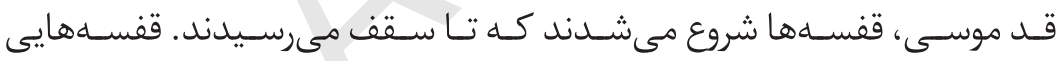

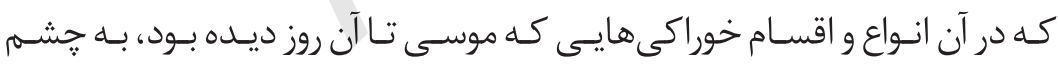

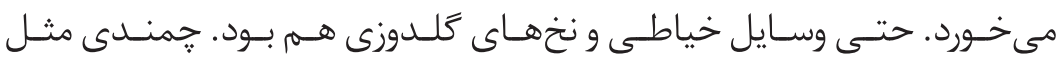

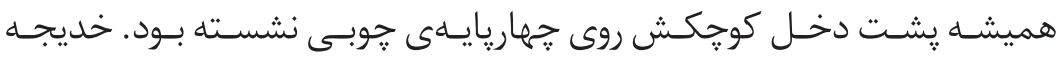

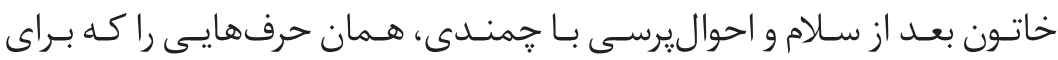

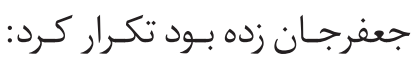
ـ برادر جان، خودت كه مى دانى يدر موسى به رحمت خدا رفته.

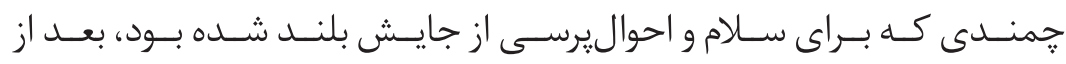




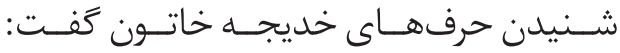
ـ خدا رحمت كند محسن خان را.

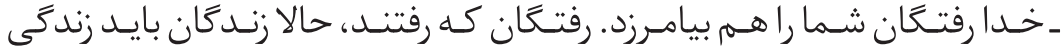

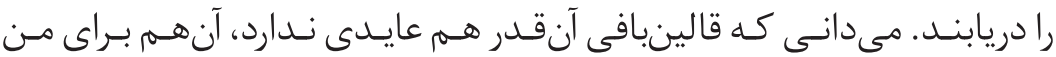

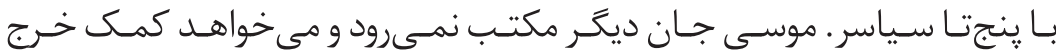

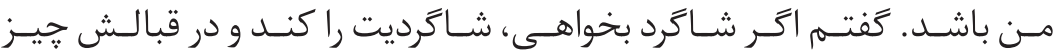
ناجيـزى كف دسـتش بخـذارى، ممنـون مى شـوم.

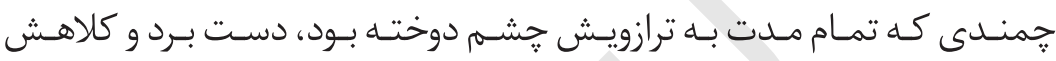
را برداشـت و سر بىمويسش راخارانـد و كفـت: ـ خواهـر جـان مـن هـم اتـر بتوانم دوسـت دارم كمكى كنهم. امـا كار و بـارم آنطور

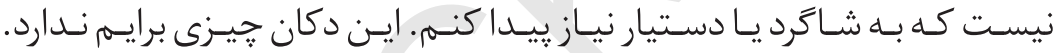

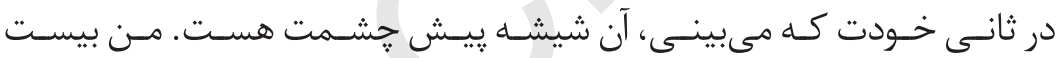

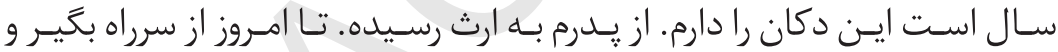

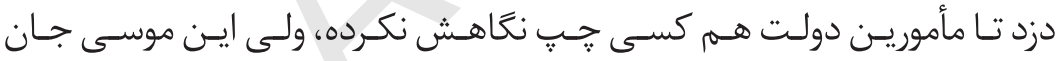

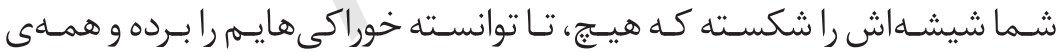

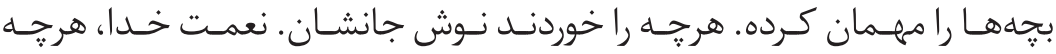
گَنـدم و مـاش و نخـود و... بـوده را هـم يخش زميـن كـرده، يـادت كـه هسـت. بــه واللـه كل روى محســنخان بـود كـهـ از سر تقصيـرش كذشـتم. مـا نـان و نمـك

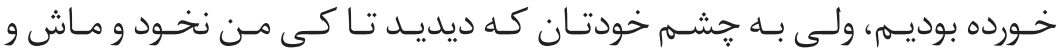

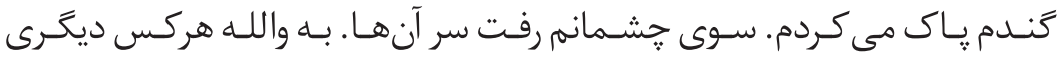

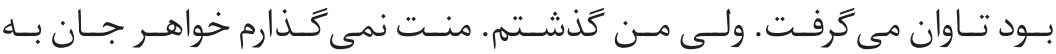




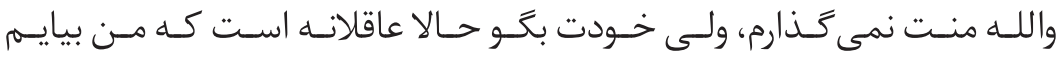

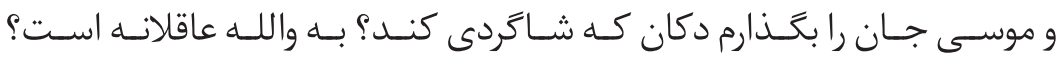

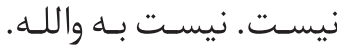

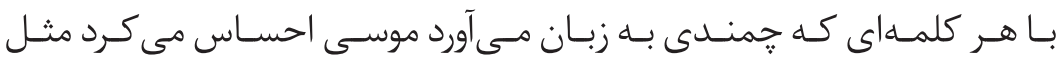

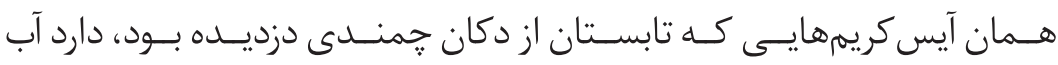

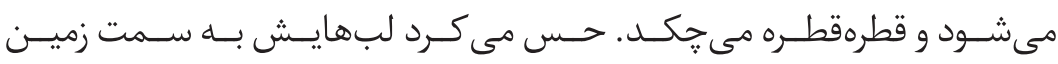

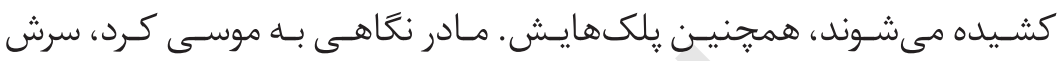
را ياييـن انداخت: ـ درست است برادر. درست مى گَّيى.

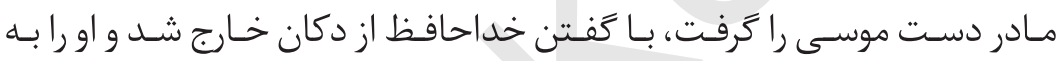
دنبـال خـود كشـيد. موسـى سردى دسـتان مـادر را بـه خوبسى حسـ مى كـرد و

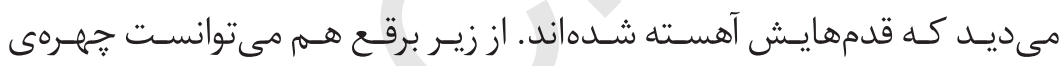

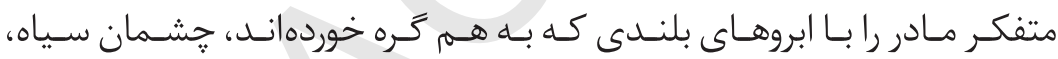
بينـى كشـيده و لبههـاى باريـك ببينـــ. حتـما خـال روى بينـى اش هـم از هـر زمـان ديخـر تيرهتر شـده اسـت. موسـى مى دانسـت مـادر هـر وقـت عصبانسى يـا

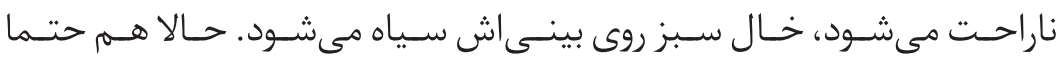

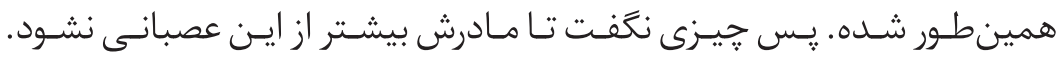

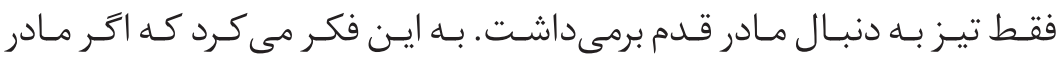

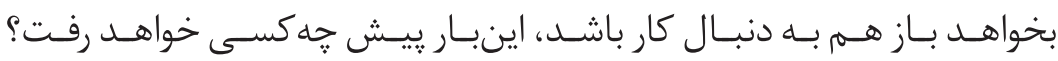

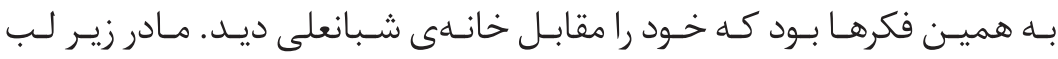
بسـمالله كَفـت و دروازه را زد. شـبان كـه در اصـل شـعبانعلى نـام داشـت، مـردى 


\section{معجزئى موسى}

درشـت هيـكل و قـد بلنـد بـا موهـاى مجعـد بـود. حـدود جهمارصـد و ينجــاه رأس

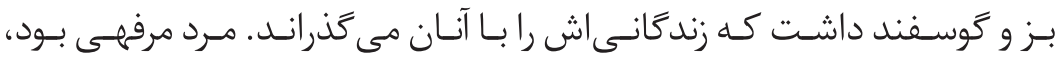
امـا كسـى را نداشـت تـا جُويانـى كَلـهاش را بكنـد. خـودش شـبانه روز در كـوه و

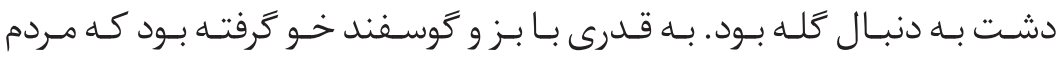
ده او را مـورد تمسـخر قـرار مهى دادنـد و مهى گفتنـد: ـموهاى مجعدش به كوسفندها كشيده و جابكى اش به بزهايش. عـدهاى هـم كـه او را مـادام جـوب بـه دسـت مى ديدنـد، يشـت سرش بـا كنايسه و

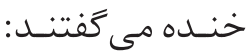
ـ جوبـت را زميـن بحَذار و دم راسـت كن، كسـى خيـال دزديـدن جوبدسـتى ات راندارن

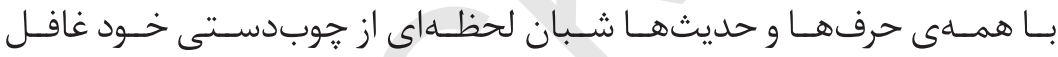
نمى شــد. حتـى موقـع نـان خـوردن هـم آن را كنـار خـود مـى خذاشـت و بعـد از

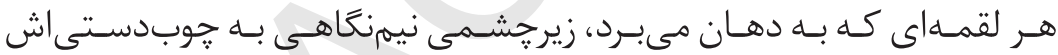

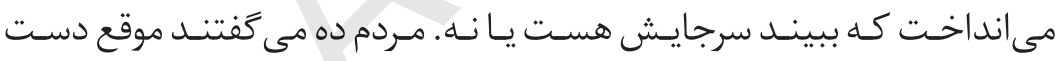

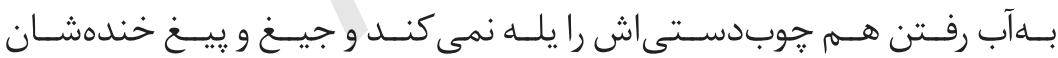

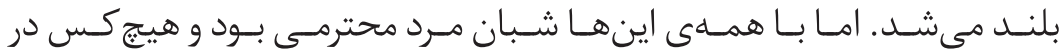
حضـورش ايـن حرفهــا را بــه زبـان نمسى آورد. شـبان كوشـش بـه هيج كـدام از

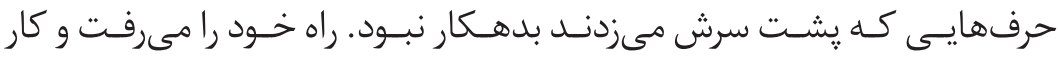
خـود را مهى كـرد. موسـى تـا بهحــال بــا او همـكلام نشـده بـود، زيـرا او صبحهـا آفتـاب نـزده كلـه را از ده خـارج مى كرد و شـبـها آخريسن نفــى بـود كـه بـه خانـه

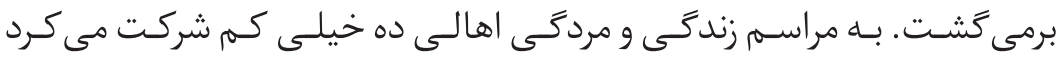




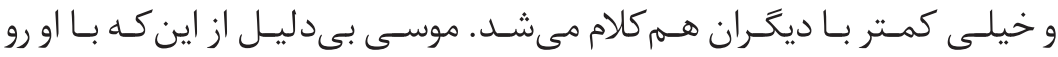
در رو صحبـت كنـد مى ترسـيد. جثـهى عظيـهاش او را بـه وحشـت مى انداخـت.

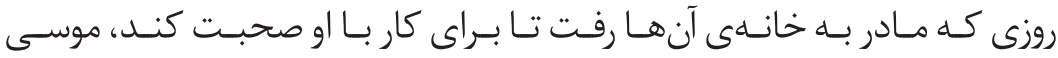
حتـى يايـش را بيـن حويلـى آنهـا نخذاشـت و همان جا يشـت دروازه منتظـر ماند. اما سرانجام روزى كه موسى بايد با شبان خان روبهرو مىشد فرا رسيد. صبـح زود، خورشـيد طلـوع نكـرده و خـروس نخوانـده مـادر موسـى را كـه اصـلا

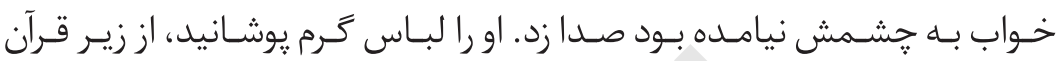
كذشتاند و بـوسـهاى بـه ييشـانى كوتاهـش زد. محبوبـه نـان و مسـكهاى كـه بيـن

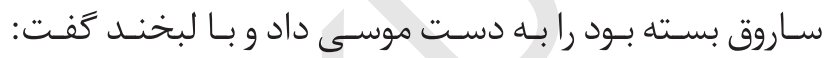
ـ خدا به همراه، مرد خانه.

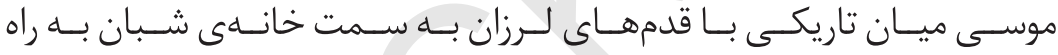

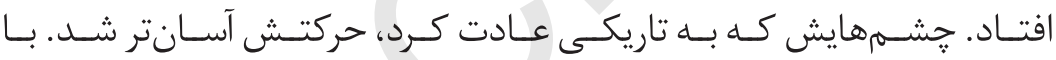

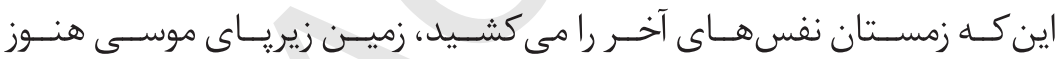

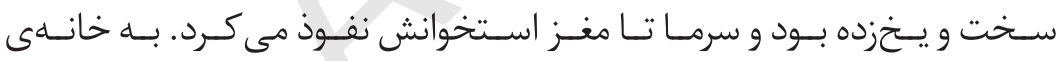
شـبان كـه رسـيد، آخريـن گَوسـفند هـم از در طويلـه خـارج شـده بـود و آرام يـى

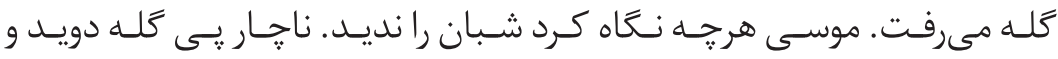

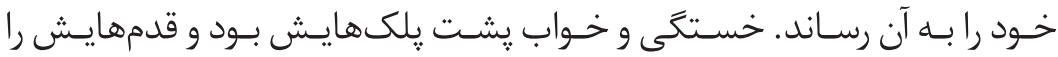

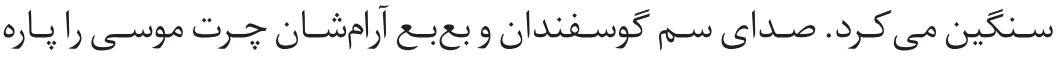

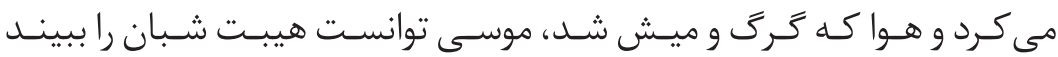

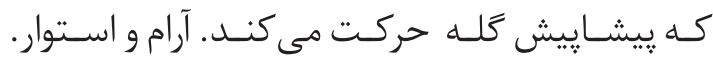

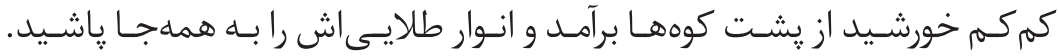




\section{معجزئى موسى}

موسـى خـود را در دشـت سـبز و فراخـى ديـد. شـبان از حركت ايسـتاد و كلـه را

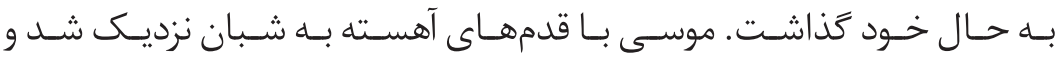
بـراى اولينبـار رو در روى شـبان بـه او سـلام كـرد و صبـح بخيـر كفـت. شـبان بـه جثـهى كوجـك موسـى نَّاهـى انداخت و بعـد بـا دسـت زميـن كنـار خـودش را نشـان داد و كفتـ:

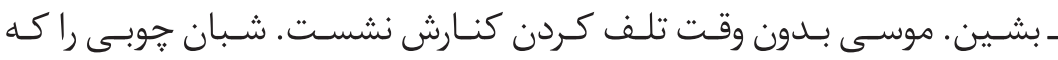

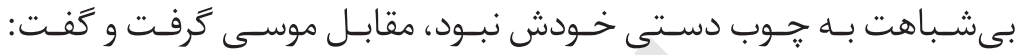

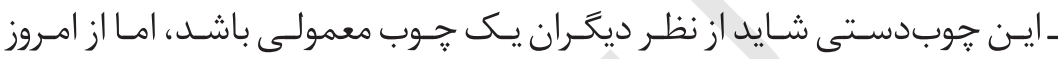
و بــراى تـو يــ جـوب جادويـى اسـت. مقـدس اسـت. حرمست و احـترام دارد.

موسى جند مرتبه سرش رابه معنى بلى بالا و يايين كرد. شبان به جشمهاى موسى خيره شد و ادامه داد: -مىى دانى جرا!

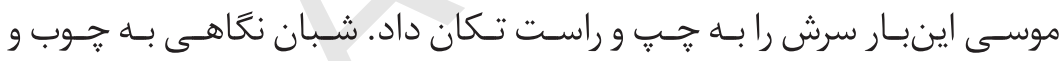

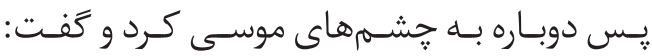
- جــون از امـروز ايسن جــوب وسـيلهى كار تـو اسـت. وسـيلهاى كـه با آن خرج شـكم

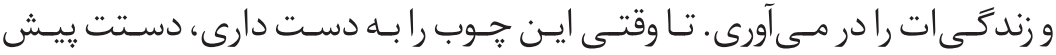

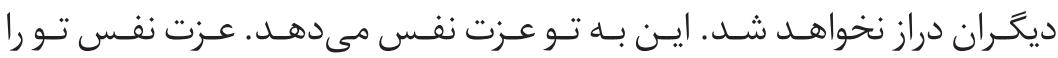

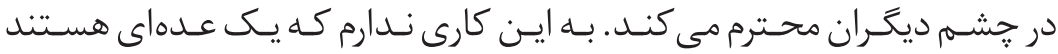

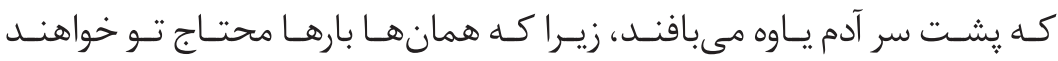
شـد، تـا وقتى كـى ايسن جــوب را بـه دسـت داشـته باشـى نمى كَويسم احتيـاج آنها 


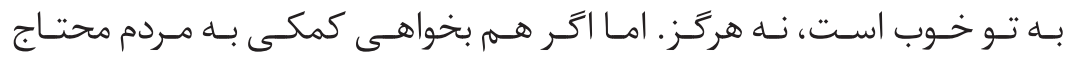

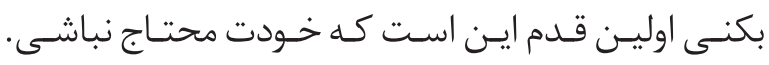

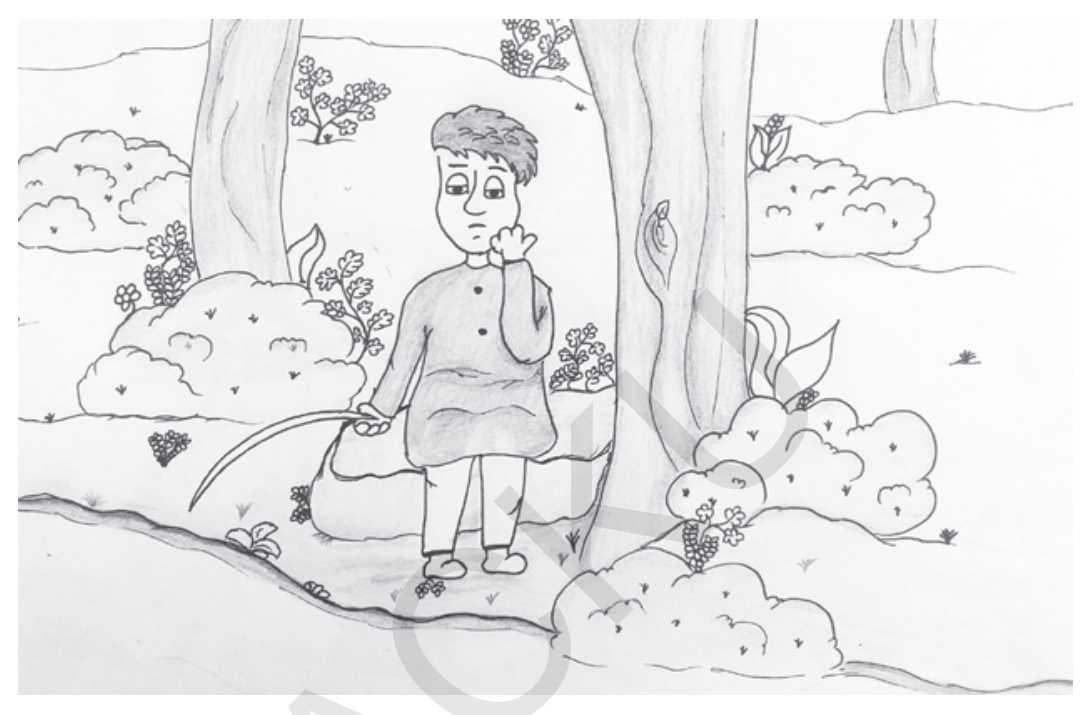

موسى تمـام مدتى كـه شـبان حـرف مسزد،، در فكر بـود و او را بـا مـلاى مكتـب

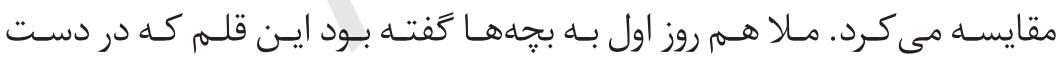

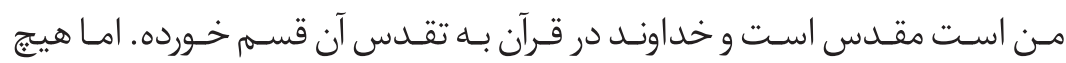

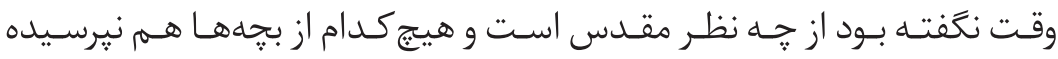

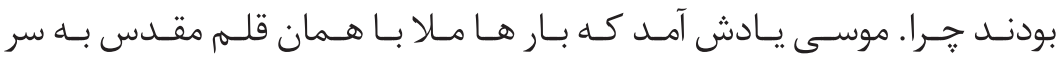

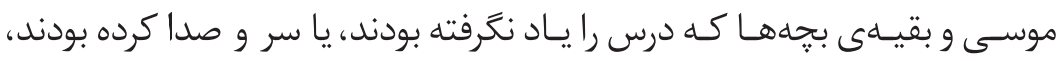

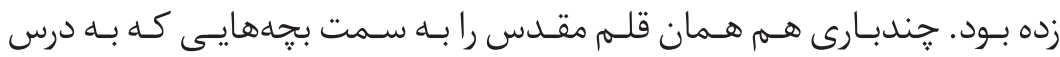

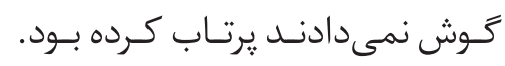


شبان بعد از مكثى كوتاه ادامه داد:

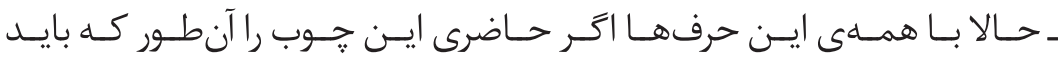

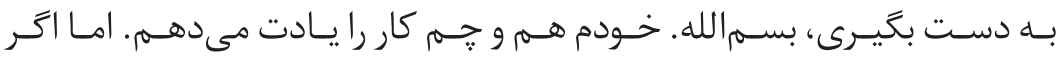

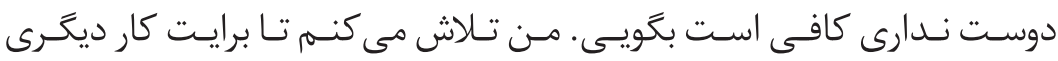

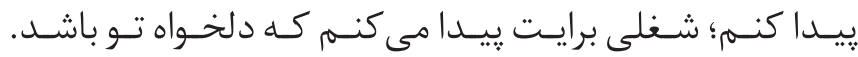

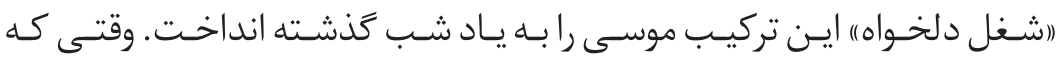

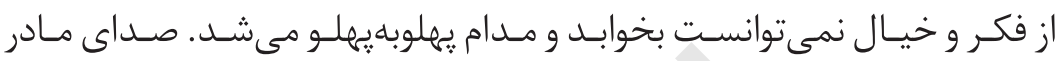
راز آرل تاريكى شـنيد:

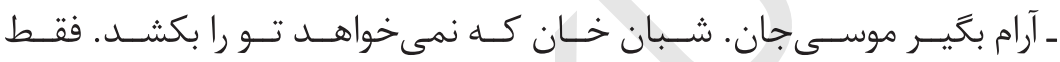

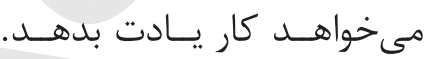
موسى با نگاهى به تاريكى گفته بود:

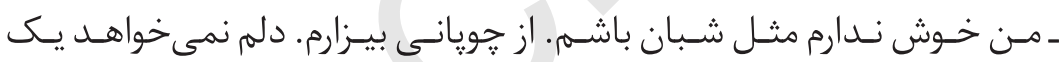
جويـان باشـم.

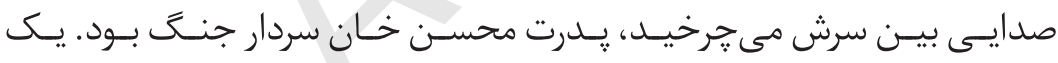

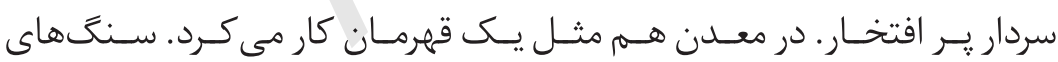

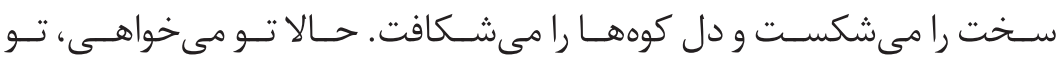

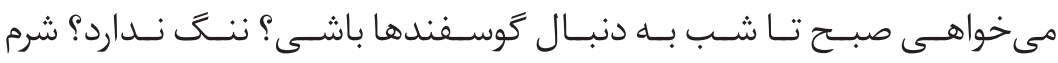
نمىشـوى از ايـن كار؟ صـداى مـادر نزديكتــر شـــ و صـداى ذهـن موسـى را خامـوش كـرد: (هميشـــ

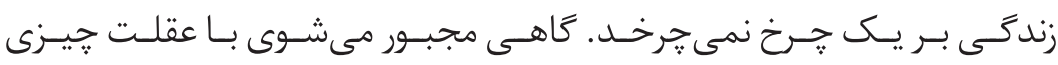

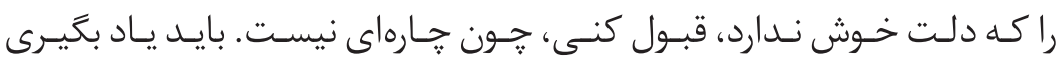


دلـت را بــا عقلـت همـراه كنـى و آن جيـزى كـهـ بــا دلـت نمى توانـى دوســش بــدارى، بـا عقلـت دوسـت داشـته باشـى." " مادر اينها راكفت و دستى به سر موسى كشيد: ـ حالا آرام بخواب بتجهام.

موسى نتوانست بخوابد، اما ديخر تكان نخورد.

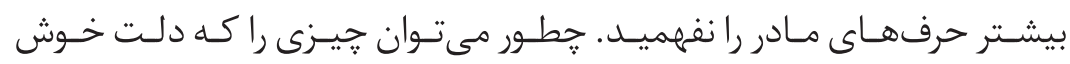

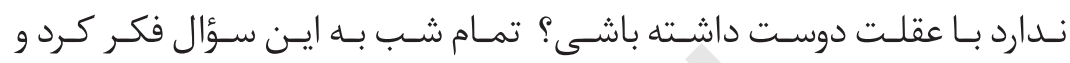
خيلى جيزهـاى ديخـر.

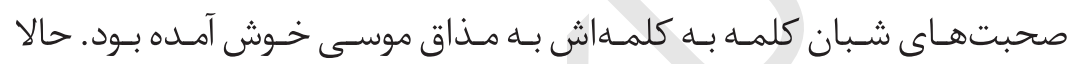

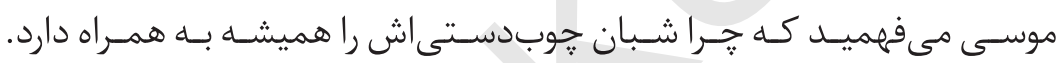

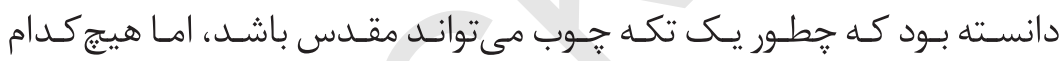

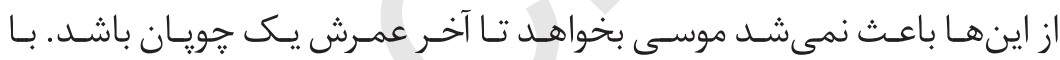
ايـن وجـود نفهميـد جــراو جطـور دسـتانش رابـراى گرفـتن جوبسى كه در دسـتان شـبان بـود، ييـش بـرد.

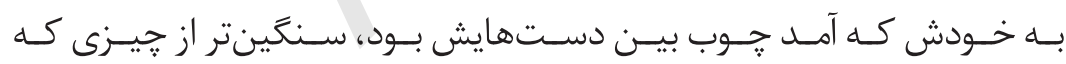

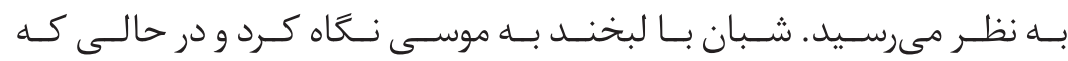
برمى خاسـت رو بــه موسـى كفــــ - بيا تا نشانت بدهم جطور مى شود يك جويّن شد، يك جويان خوب.

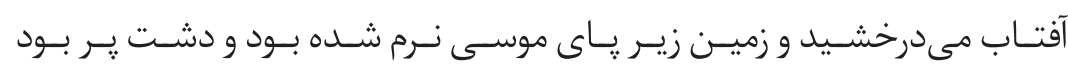

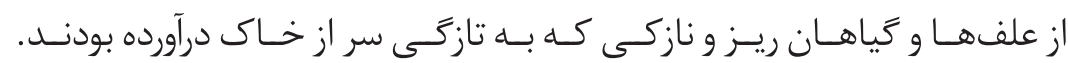

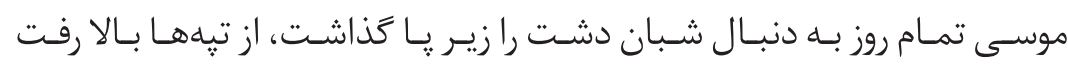




\section{معجزى موسى}

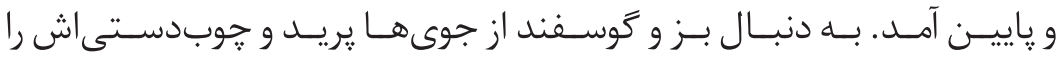

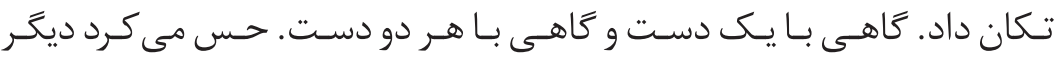

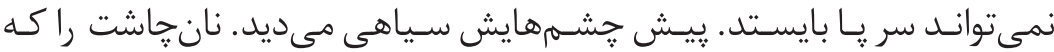
خوردنـد حالـش بهـتر شـد. بارهـا بـا خـود انديشـيد كـه اخـر در مكتـب بـود حـالا ديخَر درسـش تمـام شـده بـود و مـىتوانسـت بـه خانـه بركـردد. بـه يـاد تك تك دوسـتانش افتـاد. حــالا محمـد بـه خانـه برمى كَردد يـا بـا بقيـهـى دوسـتانش بـه

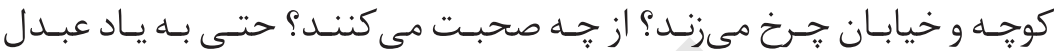
افتـاد، حتـما حـالا كـه مـن نيسـتم جايش فـراخ شــهـ در نظـرش آن روز از هــر روز

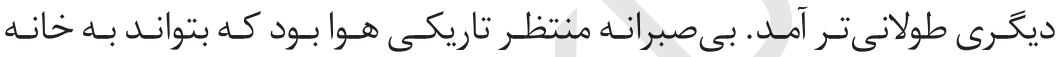

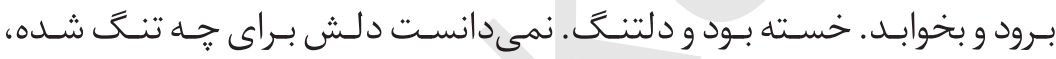

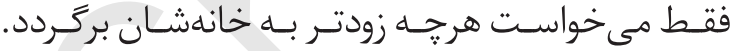
كم كمم انتظـار بـه يايـان رسـيد. غـروب كـه شـد شـبان بـه او يـاد داد كـه جطـور بايـد كلـه را جمـع كنـد و سرانجـام بـه سـمت خانـه راهـى شـدند. هــوا تاريـك تاريـك بـود كـه موسـى بـه خانـه رسـيد. *جــراغ خانـه روشـن بـود. در نـزده، مـادر در را بـاز كـرد و بـه موسـى خسـته نباشسى كفـت. ـ صداى يايت راشنيدم، فهميدم آمدهاى.

موسـى سـلام كـرد، از حويلـى حذشتـ و وارد خانـه شـد. خواهرهايش همـه در يك

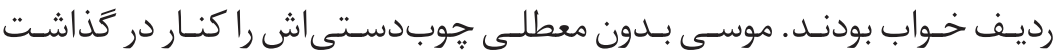
و بيـن رخـت خــواب يهـن شـدهاش كنـار ديـوار، خزيـد و لحـاف را روى سر خـود كشـيد. مادر يرسـيد: ـ مخر نان نمى خورى؟ 
موسى از زير لحاف باصدايى آرام جواب داد: ـنه. خستهام. مي خوابم. مادر جراغ راخاموش كرد وخوابيد.

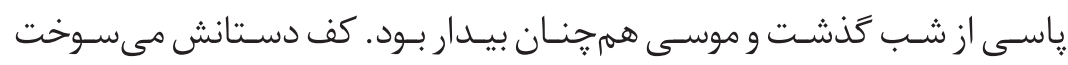

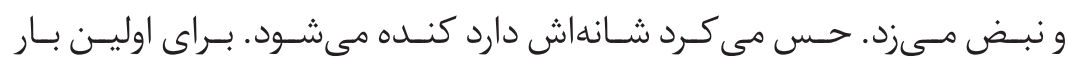

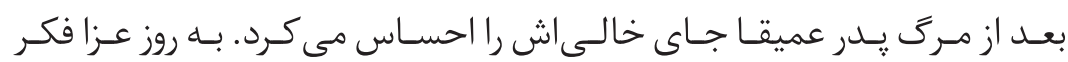
مى كـرد، بـه محبوبسه كـه بــه سر خـودش مسىزد و مى كفــت - آيتيم شديم، يتيمم شديم.

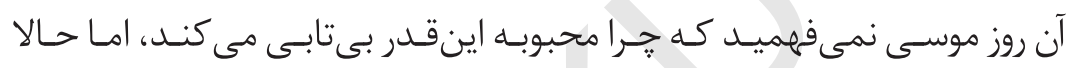

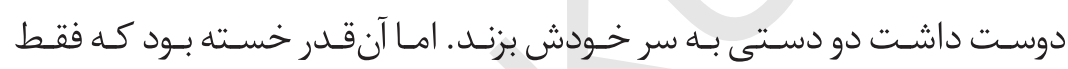

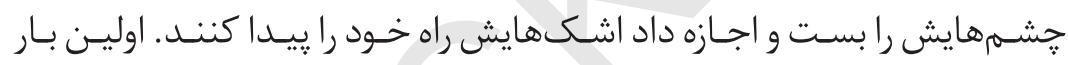

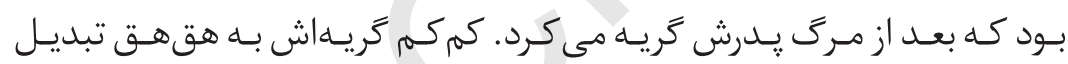

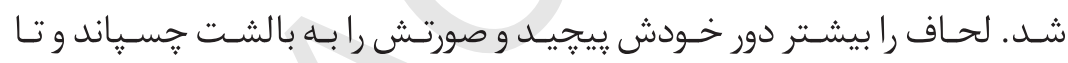
مىتوانست زار زار مى زىريست. 


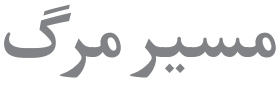

موسـى كَلـه را بـه سـمت جشـمه كشـيده بـود و حـالا كنـار جشـمه روى تختـه سـنَى نشسـته بـود. جــوب دسـتى اش را در بغـل حذاشـته و دسـت راسـتش را

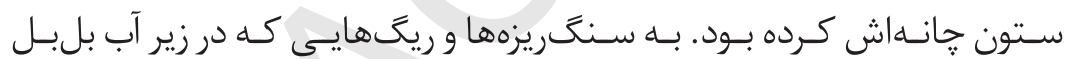

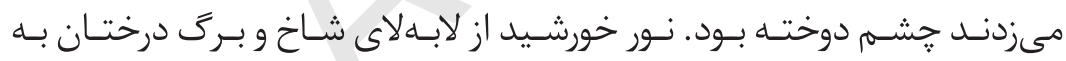

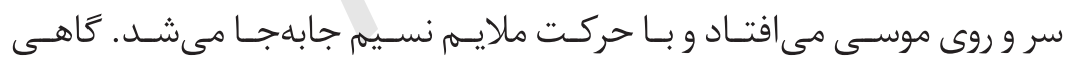

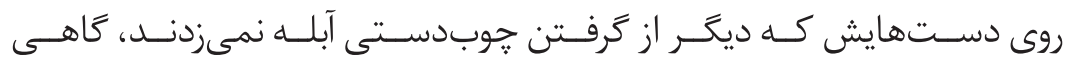

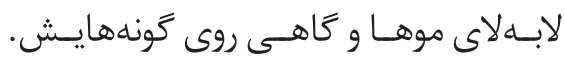




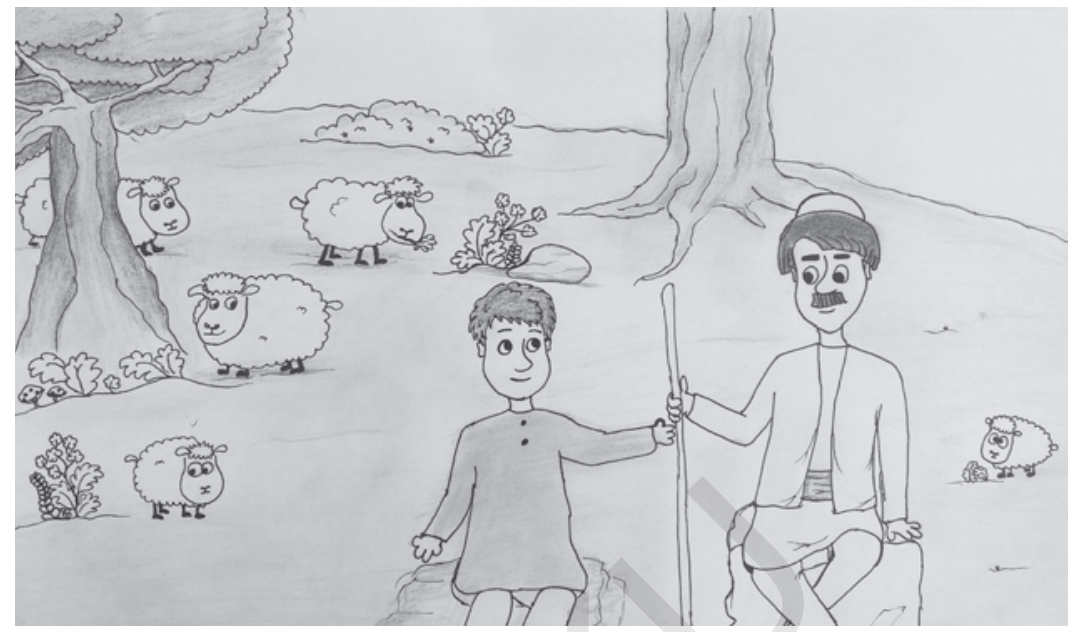

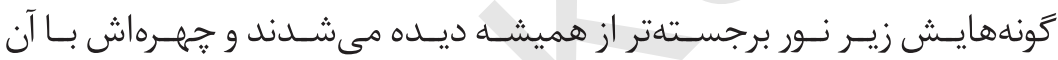

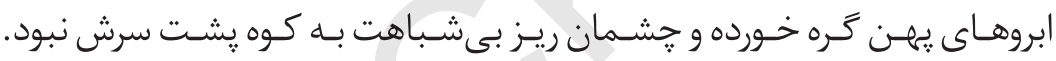

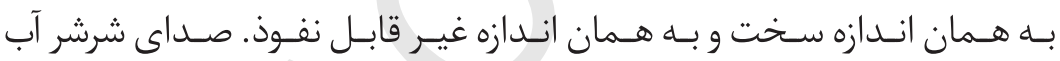
روحسش را نـوازش مسى داد و او را بـه دنيـاى فكـر و خيـال مى.بـرد.

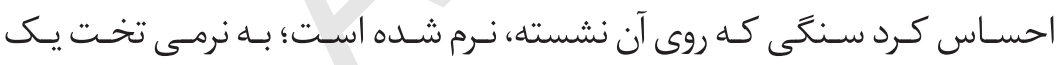
يادشـاه. دسـتى بـه موهايش كشـيد. حواسـش بـود تـاج خيالـى اش از سر نيفتد.

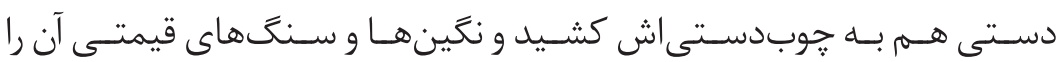

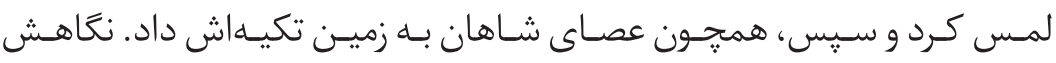

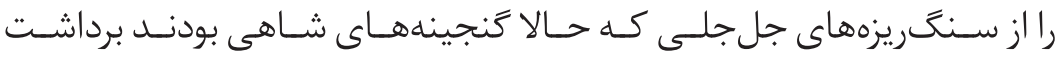

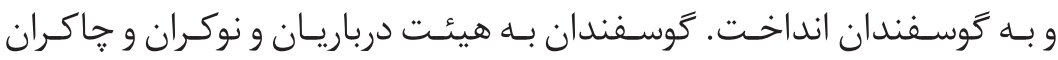

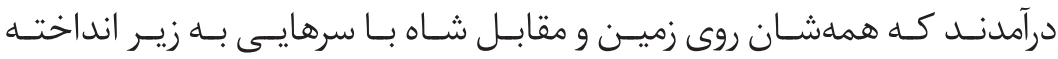
نشسـه بودنـد. موسـى بـادى بـه غبغـب انداخـت و بـا صـداى بلنـــ يرسـيد: 
ـ فايدهى اين همه طلاو جواهر جيست؟

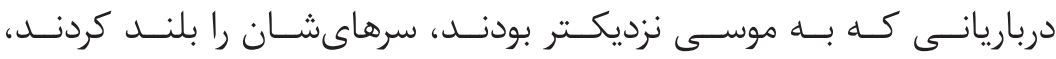

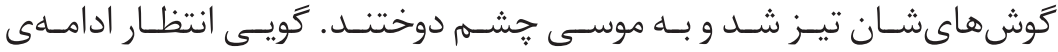

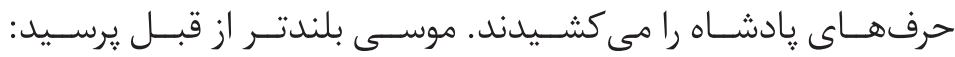
ـ اين همه زر و نقره به جه كار مى آيند اخر نتوانند جلو مرگ را بخيرند؟

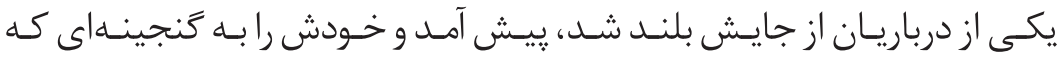
مقابـل موسـى بـود رسـاند. صورتشش را بيـن طلاهـا فرو بـرد، مثـل اين كـه بخواهد

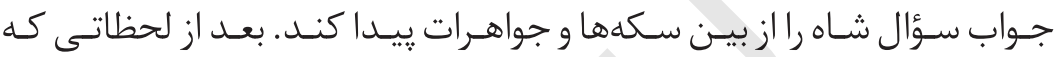

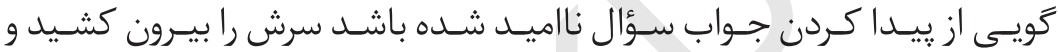

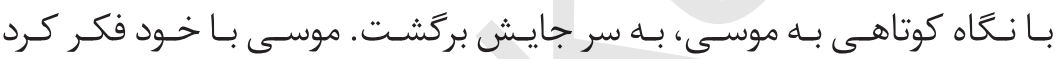
شـايد بــه يـك جـادو نيـاز داشـته باشـد؛ جادويسى كـهـ او را در مقابـل هـر بـلاى

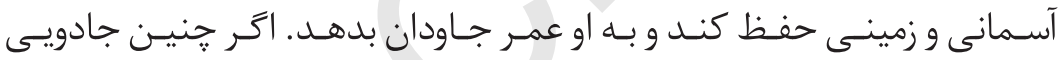

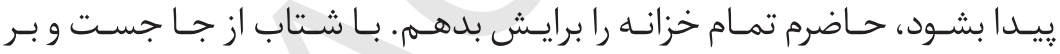
بلنــى تخـت ڤادشـاهى اش ايسـتاد و عصايـش را رو بـه حاضريـن بلنـد كرد:

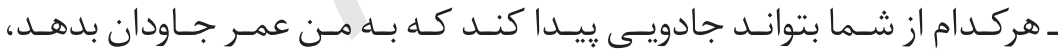

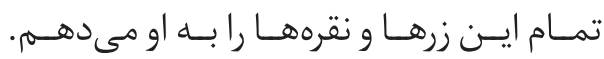

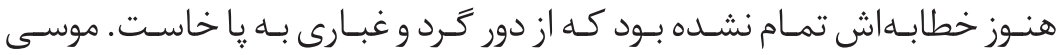
در فكـر شـد، حتـما تيمهايسى كـه يُيـش مى آينـد، جادوخـــان و ملاهايسى هسـتند

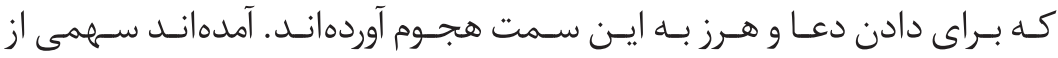
خزانهى شـاهى داشـته باشــند.

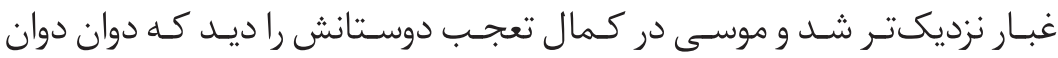


بــه سـمت او مـى آينـد.

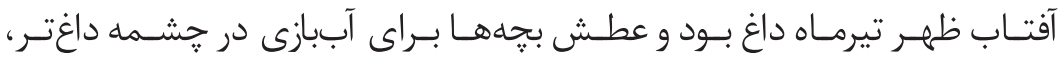

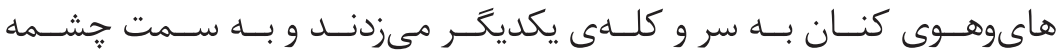

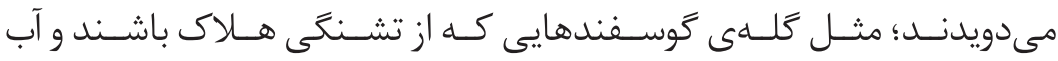
ببينتـلـ. محمد لبخند زد: ـ خوب است كه از يسش برآمدى. موسى يرغرور لبخند زد : مور: ـ ها برآمدم. تا جقدر مهى توانى نفس نكشى؟ محمد خندان، قيافهاى متفكر به خود گرفت و بعد از مكثى كوتاه گفت: ـ شايد بيشتر از تو. -ببينيمم. - 20بينيم. و هـر دو همزمــان بــه زيــر آب رفتنـــ. زيــر آب شـفاف بـود و موسـى مى توانسـت محمـد را ببينـد كـه دسـتهايش را آرام تـكان مهى دهـد. محمـد هـم بـه موسـى

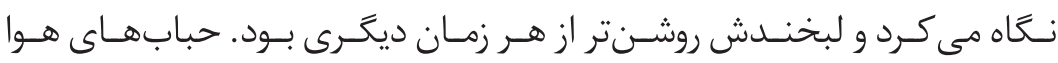

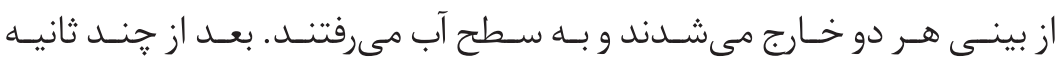

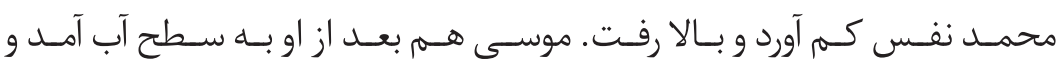
هميـن كـه سرش را از آب بيـرون آورد نفس عميقى كشـيد. محمـد ييـش آمـد و

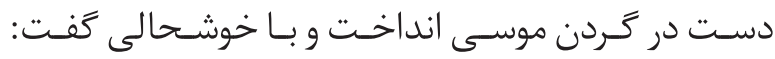
ـ رفيق من هميشه برنده است. 


\section{معجزئى موسى}

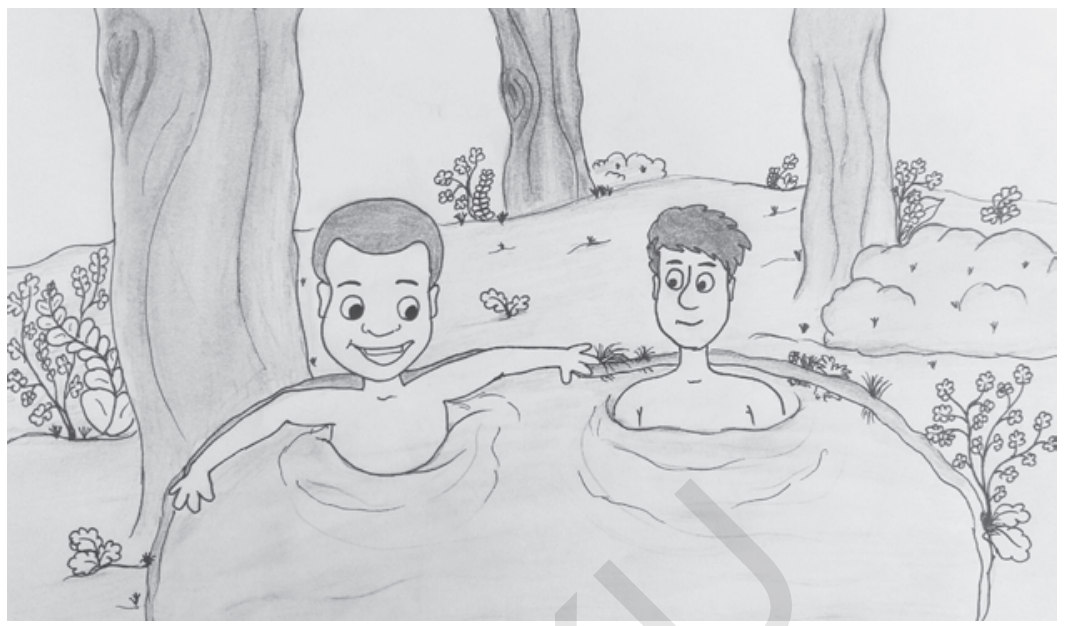

عبــل كـه شـاهد حرفهـاى آن دو بـود بـا شـنيدن (برنـده)) حسـادتش كل كـرد.

$$
\text { ييسش آمـد و جيـغ كـرد: }
$$

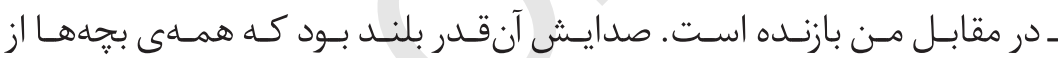

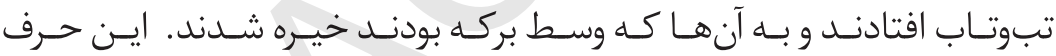

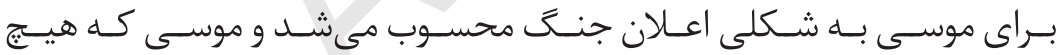
خـوش نداشـت در مقابـل عبـدل كـم بيايـد جـواب داد:

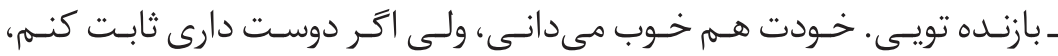
بيـا كـه مسـابقه بلهيهم.

عبدل نيشخندى روى دهان جيغش نشاند و گفت: ـ خواهيم ديد كى بازنده است.

$$
\text { ـ خوسى اخم كرد: }
$$


صداى بجه ها به كفتن كلمهى مسابقه، مسابقه ... بلند شد. محمد دستش را بالا برد و گفت:

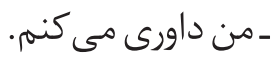

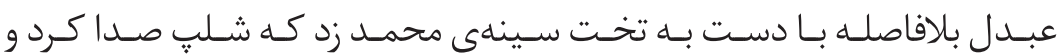
كفـت:

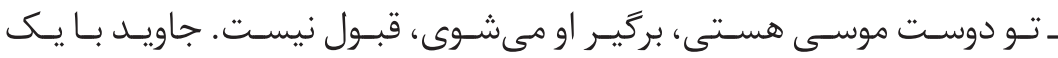

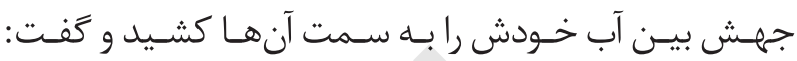

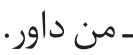
موسى و عبدل به او نغاه كردند و همزمان كفتند:

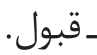

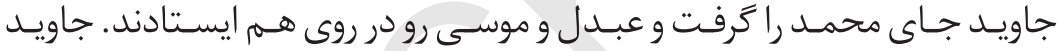
دسـت راسـتش را همجهـون يرجمـى بـالا بـرد و بعد از كفتن يكى، دو، سـه با شـدت ياييـن آورد. موسـى و عبـدل نفس عميقـى كرفتتـد و بلافاصله بــهـ زيـر آب رفتنـد.

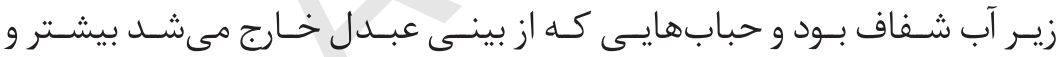

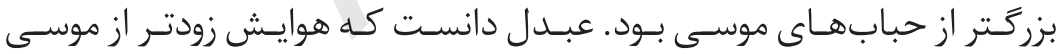
تمـام خواهــ شـد، يـس نيرنـَ زد و شروع كـرد بـه كـج و كوله كردن صورتش.

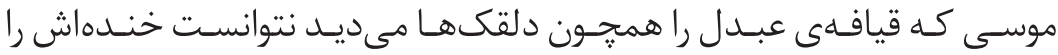

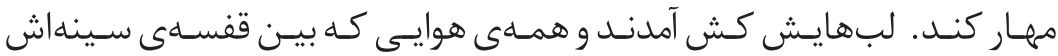
حبـس كـرده بـود، بـهـ شـكل حبابهــاى ريـز و درشـت از دهـان و بينـى اش خارج شـدند. موسـى ديخـر نتوانسـت زيـر آب بمانـد، بـالا آمـد و نفـس عميقـى كشـيد.

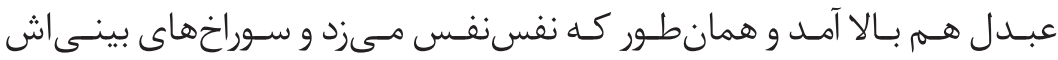




\section{معجزهى موسى}

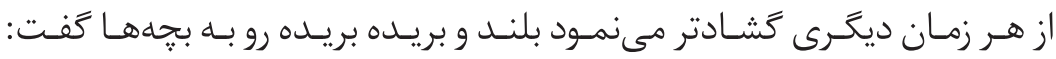
ـ من برنده شدم، من بردم، موسى، خان، بازنده، بازنده.

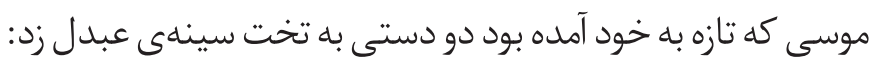
ـ دغلباز، دغل باز، قبول ندارم، قبول نيست، تونيرنت زدى. عبدل خودش را از تكوتاز نينداخت:

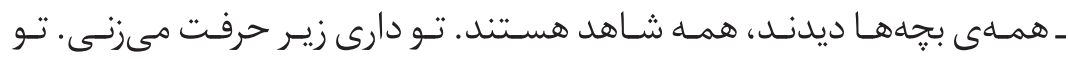
جيـزى بحَّو جاويـد... تـو داورى، هـا... جاويد ميان آب ييش آمد، دست عبدل را كرفت و بالا برد و گفت: ـ عبدل برندهى مسابقه است، تمام.

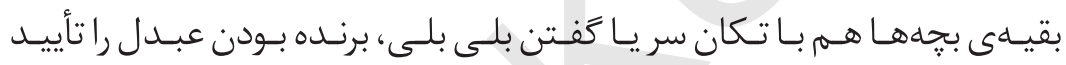

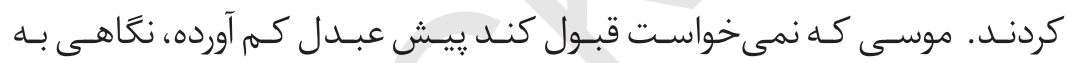

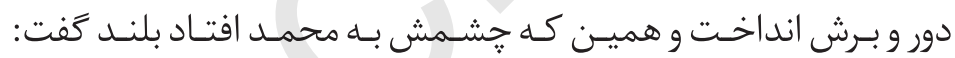
ـ تو يك جيزى بـَو محمد.... عبدل نيرنگ كرد... ميان آب مراخنداند.

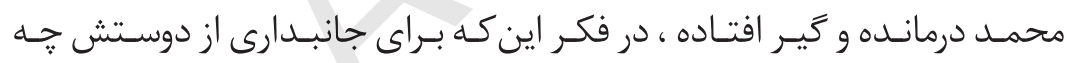

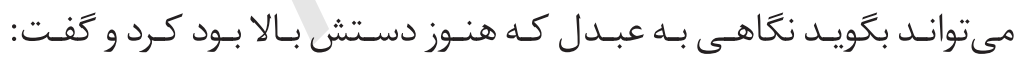

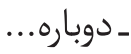
عبدل و موسى همزمان كفتند: - :جى؟ :جى دوباره؟

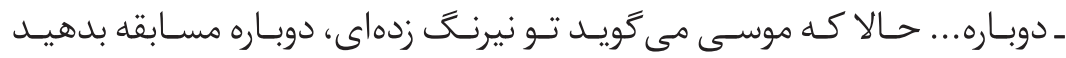
تـا ثابـت شـود.

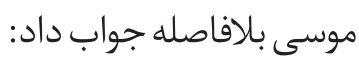




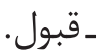

عبدل دستش را از دست جاويد بيرون كشيد و زير بغل زد:

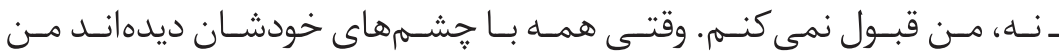

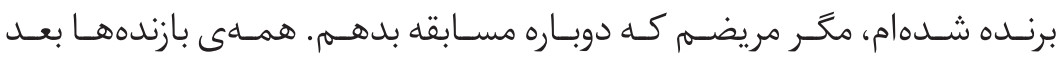

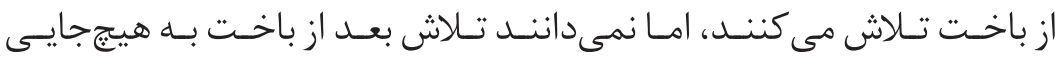
نمسرسـد. بيهـوده اسـت. موسى به خود گرفت و ييش يريد: ـ من بازنده نيستم. بازنده توييى دغل باز.

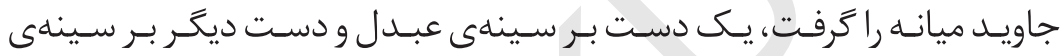
موسسى متفكرانـه كَفت: - يكى كار ديخر مى كنيم. همd يرسيدند: (r)

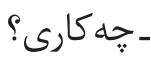

جاويد يشت جֶمه هايش رانازك كرد و بادى به غبغب انداخت:

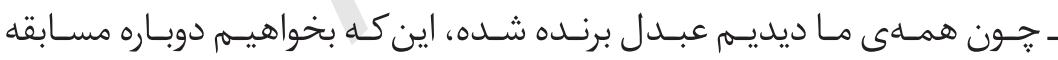
بدهـد در حق او بـعدالتى مى شود. ولى مى توانيـم از موسـى بخواهيسم كـه اخـر

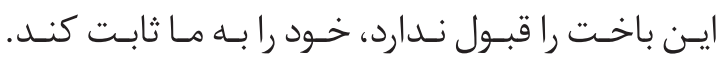
موسى بـى صبرانه يرسيد: - جطور؟ جطور ثابت كنم؟ تنمها بروم زير آب؟ جاويد ₹فت: ـ ـنه، يك كار ديخر ، مثلا، مثلا... 


\section{مeزجزى موسىى}

عبدل كه انغار فكرى شيطانى در سر مىيروراند لبخند زد و كفت:

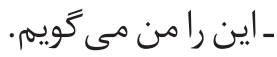
بعـد آرام خـود را از بركهـ بيـرون كشـيد و همان طـور كهه رو بـه سـوى كـوه داشـت دسـتش را سـايبان جشـمانش كـرد و ادامـه داد: ـ مثلا از كوه بالا بروى، آن هم از مسيرى كه من مي كَّيم.

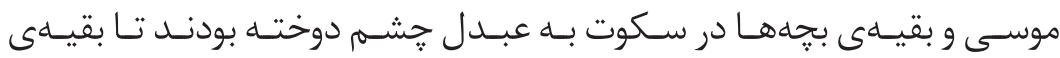
حرفش را بزنسد.

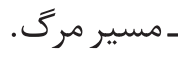

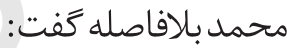

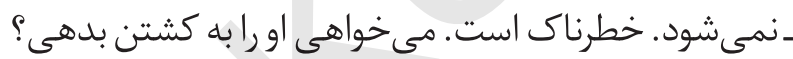

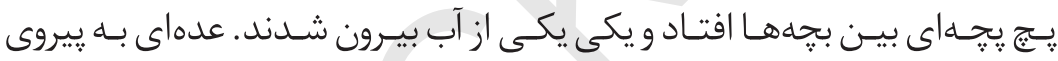
از عبـدل كـه حـالا روى سـنَـهاى داغ كنـار آب دراز كشـيده بـود، تن هاىشـان

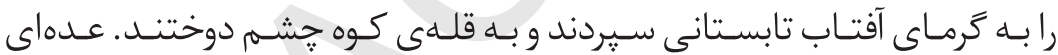
هـم لب آب نشسـته و منتظر تصميـم موسىى بودند.

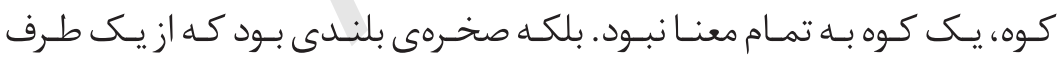

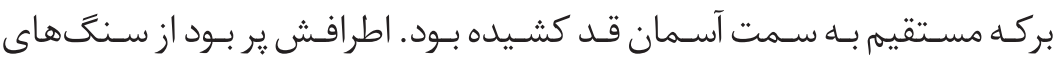

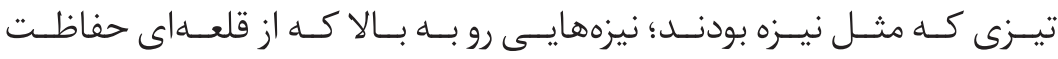

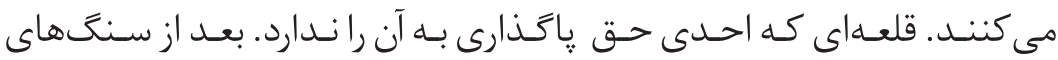

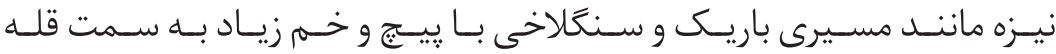

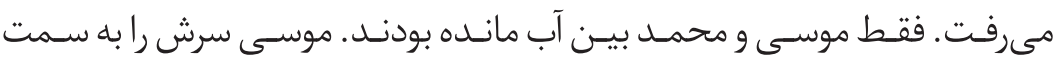

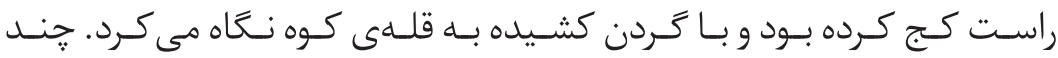




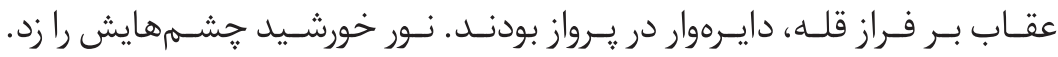
محمــد كـه موسـى را در فكـر ديـد، دسـت كذاشـت روى شـانهاش و كفـت: ـ موسـى قبـول نكـن. ايـن كار خطرنـاك اسـت. موسـى دسـت محمـــ را يـس زد و

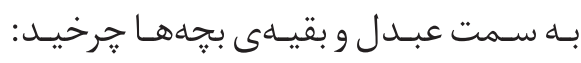

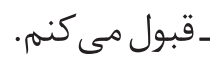
محمد از يشت دست موسى را كشيد:

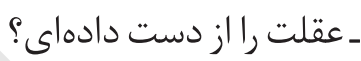
موسى با قهر به جشمهاى محمد نثًاه كرد: - بايد ثابت كنم كه بازنده نيستم. ـ محمد هم اخم كرد: عبــل حسـ مى كـرد هـر آن امـكان دارد موسـى از حرفش بركـردد. بـراى اين كـه

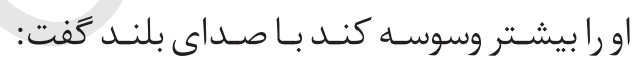

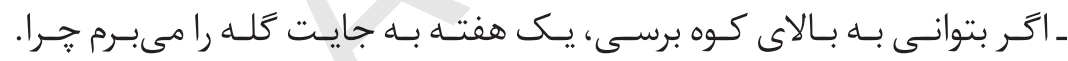

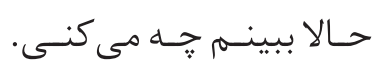
محمد اوف كشيببى عدالتى موسى به سمت عبدل رفت و باصداى بلند رو به هملى بجهها كفت: ـ قبول مى كنم. از كوه بالا مى لـروم.

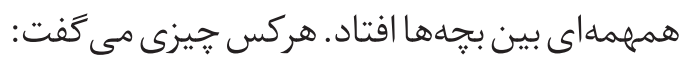

$$
\text { ـ ـ ـ ـ شرير شرزه موسى... }
$$




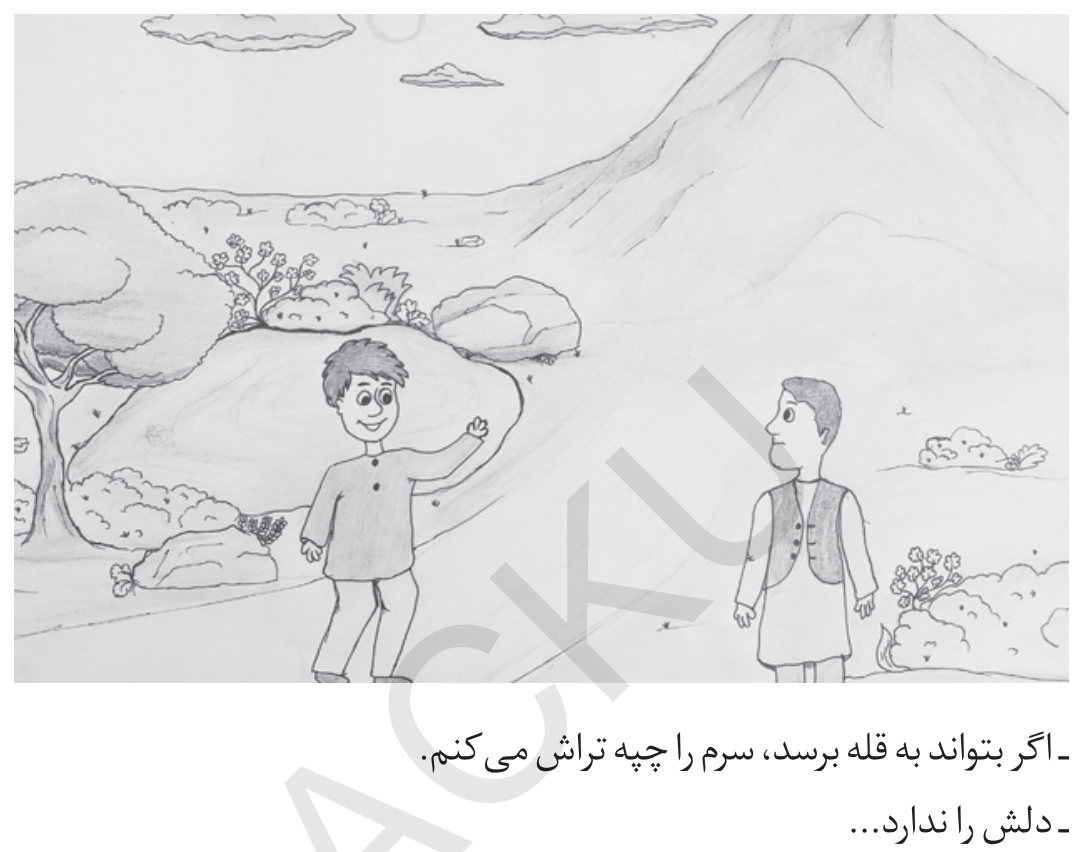

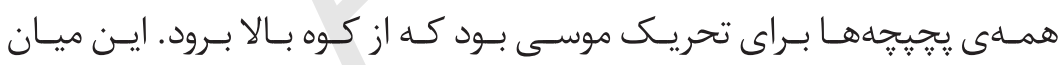

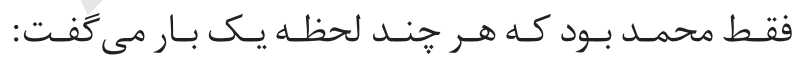

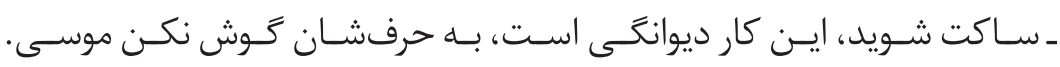

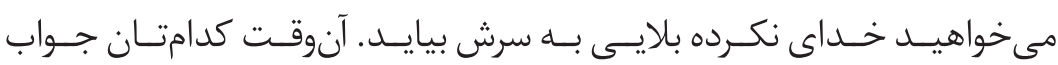

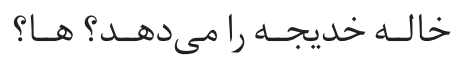

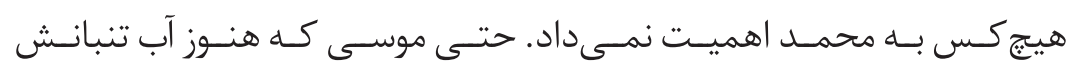

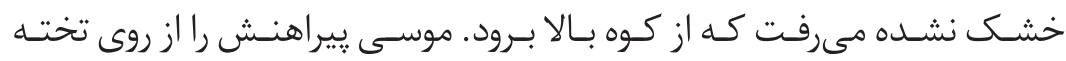

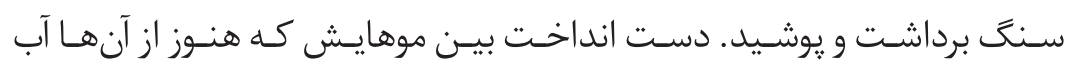




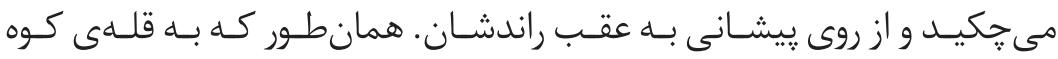

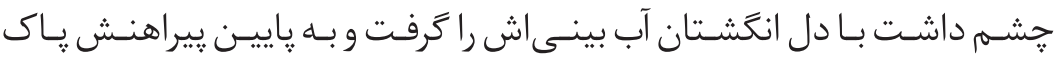

$$
\text { كرد. بـا خـود زمزمـه كرد: }
$$

ـ نشانت مى دهم كلاغ بدخبر. نشانت مى دهم بازنده كيست، برنده كيست.

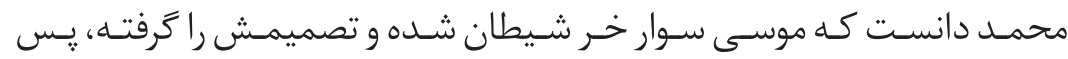
سـاكت شـد و در دل بــراى يــــروزى دوسـت و رفيـق خـود دعـا كـرد. خــا خــدا مى كـرد كـه اتفاقـى برايـش نيفتـد. هـم دلـش مى خواسـت موسـى بتوانـد از كـوه

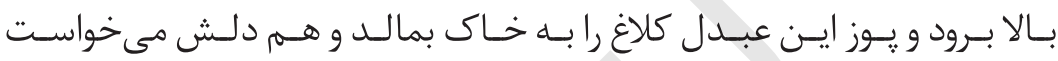

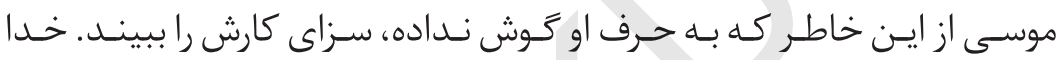

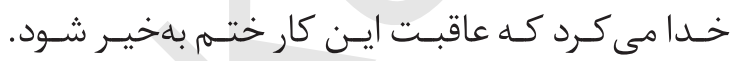

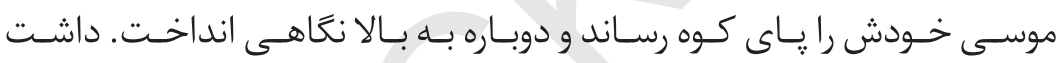
مسـير بـالا رفـتن را بـه ذهنـش برانـداز مـى كرد. تفـى بـه كـف دسـتانش انداخـت

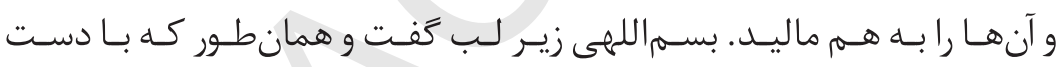

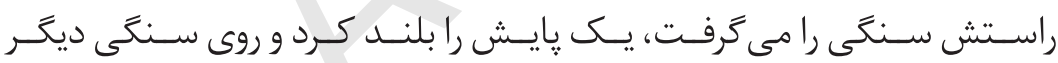

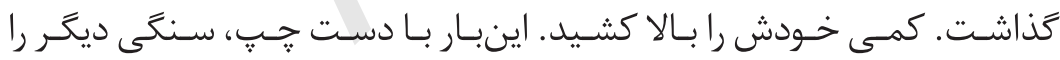
كرفت و بـاز هـم خـود را بالاتـر كشـيد. تمـام مـدت سـى مى كـرد خـودش را بــه

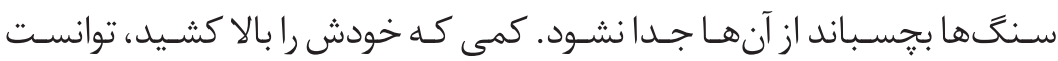

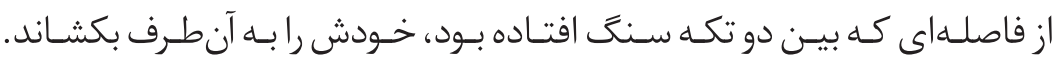

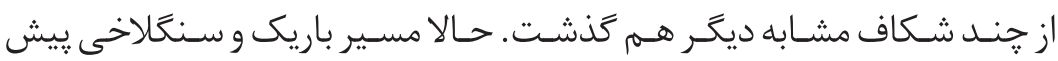
رويـش بـود. از ايـن مسـير جيزهــاى بـدى شــيده بـود. بارهـا قصـهى جويانانسى را

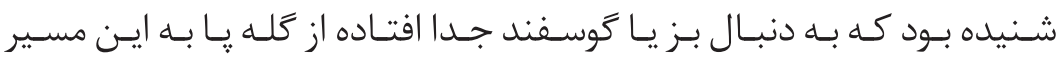


معجزمى موسى

كذاشتها بودند. امـا از بلندى سقوط كرده و مرده بودند. بيى مود نبود كه به

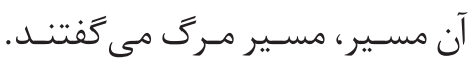




\section{تكهاى از كوه}

زمانسى كه موسـى بـراى بـالا رفتن از كـوه تـلاش مى كرد، محمـد بـه دل آنتـاب،

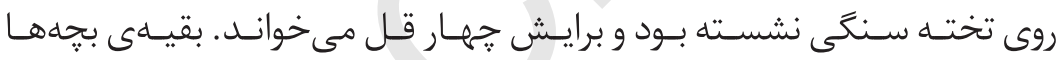

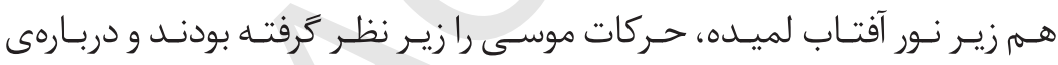

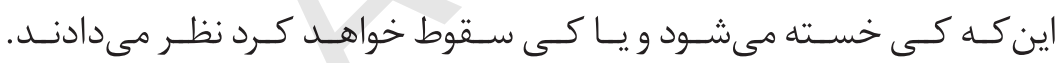

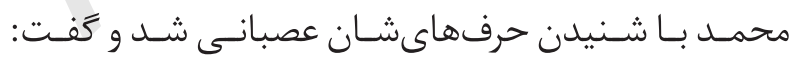

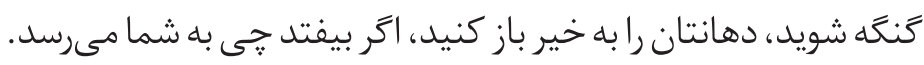

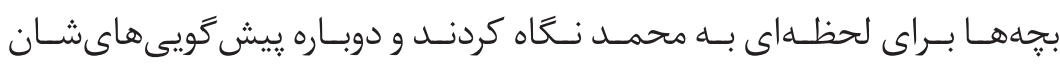

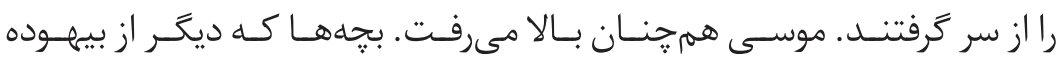

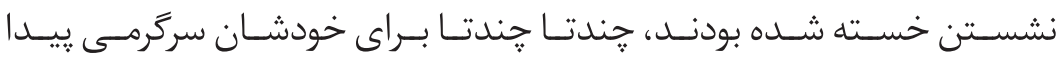

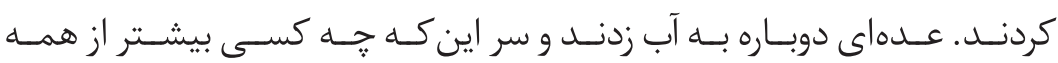

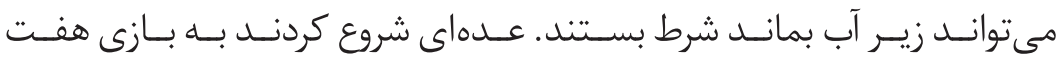


سـنَ و دنبـال هـم دويـدن و...

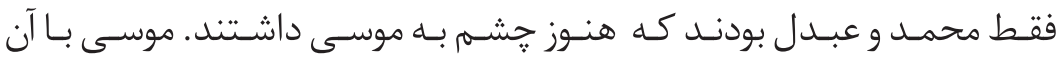
ييراهـن تنبـان قهـوهاى حـالا همجــون تكـهاى از كـوه، تشـخيص دادنش سـخت شـده بـود. اتـر از هـمان اول حركتشش را بـا جشــم دنبـال نكـرده بودنـد، حـالا نمى توانسـتند بفهمنـد دقيقـا كجاست. بعـد از آبــازى، بـىتحركى زيـر آفتـاب

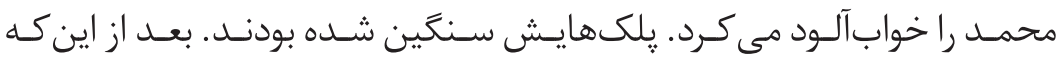
جندبـار آنهـا را از هـم كَثـود، ديخَر نتوانست مقاومت كند. جشـمانش را بست و غـرق در خــواب شـد.

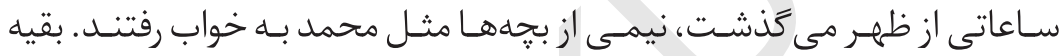

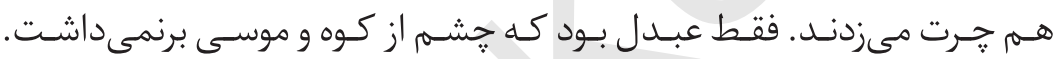

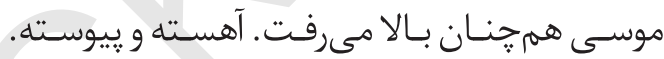
خورشـيد آرام آرام جايسش را در آسـمان عـوض مهى كـرد و مـىفت تـا يشـت كوههـا ينهــان شـود. ابرهـا همهــون ينبههـاى آغشـته بـه خــون در دل آسـمان يراكنـده بودنـد. محمـد جشـمهايش را بـاز كـرد و بـا دسـت آنهـا را ماليـد. هنـوز زيـج

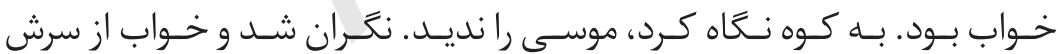

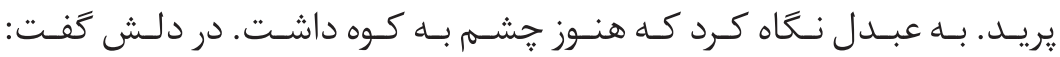

$$
\begin{aligned}
& \text { "دشـمنىى از هــر نيرويـى قوى تـر اسـت.)" } \\
& \text { بلند و بريده، بريده يرسيد: } \\
& \text { ـ موسى، موسى كجاست؟ }
\end{aligned}
$$

عبدل بدون اين كه يلك بزند و نگَاه از كوه بَيرد جواب داد: - روى كوه است، ولى مسيرش راعوض كرده، نمىبينى؟ 
موسى همرجنـان از كـوه بـالا مىرفت. مسـير سـنَكلاخى هرجه بـه قلـه نزديكتر

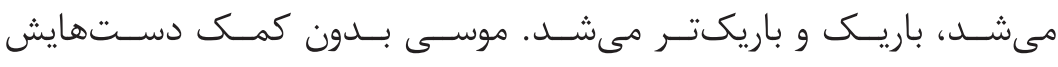

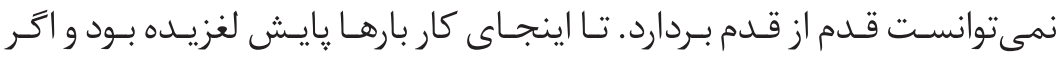

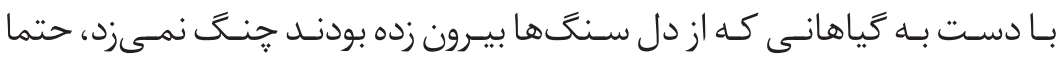

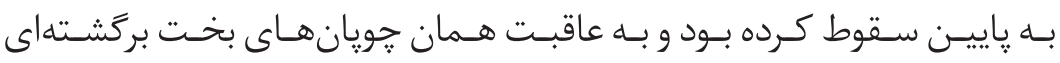

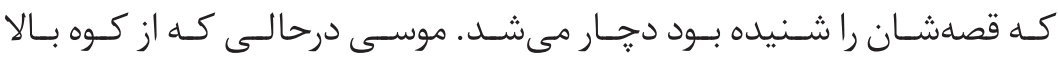

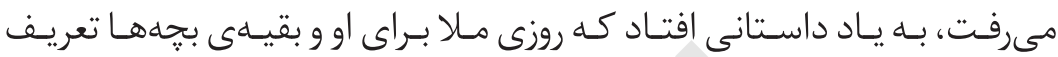
كرده بـود.

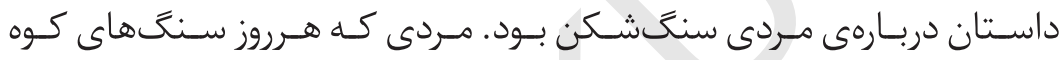

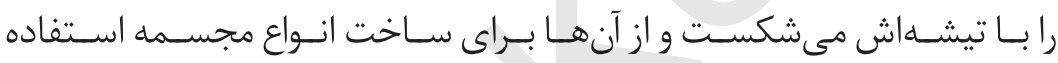

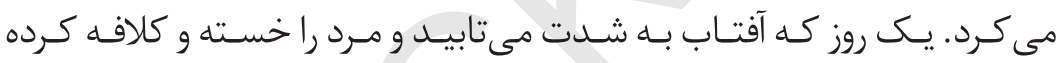
بـود، مـرد رو بـه خورشـيد كرد و كفـت:

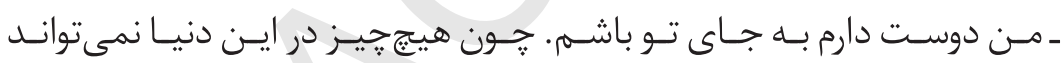

$$
\begin{aligned}
& \text { بـا تـو مقابلـه كنـد. } \\
& \text { خورشيد جواب داد: } \\
& \text { ـ اشتباه مى كنى. }
\end{aligned}
$$

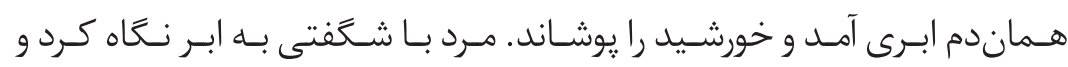
كفتـ:

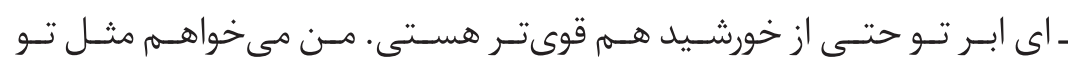
باشهم.

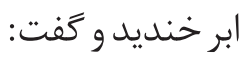




\section{مeزجمى موسىى}

- جيـزى وجــود دارد كـه از مـن هـم قوىتـر اسـت. در هميـن هنـخام بـادى وزيــ و ابـر را بـه كنـارى فرسـتاد. مـرد اينبـار از بـاد يرسـيد:

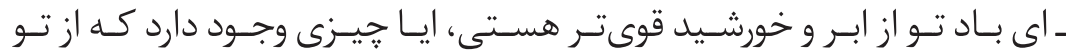
قوى تـــ باشــــ آهى كشيد و گفت:

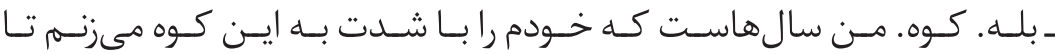
ذرهاى او را تـكان بدهـم، امـا هنـوز نتوانسـتهام ايسن كـوه را حتـى بـه انـدازهى يكى دانسهى كَندم، از جايسش تكان بدهـم. مرد به كوه نگاه كرد و كفت: ــ اى كـوه آيـا ابـر درسـت مهى گويـد و تـو قوىتريـن موجـود روى زميـن هسـتـى؟ آيـا جِيـزى هسـت كـه از تـو هـم قوىتـر باشـد؟ كوه نَّاهى به مرد كرد و گفتت:

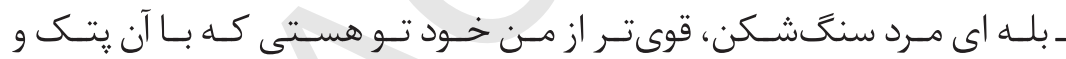

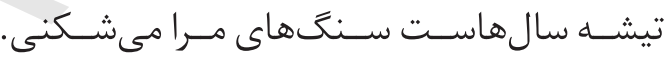
مـرد هـم متعجسب بـه دسـتها و وسـايل كارش نـعاه ميى كنـد و از اين كـه بـهـ جـاى خورشـيد و ابـرو بـاد و كـوه و... نيسـت، خوشـحال مـىشـود.

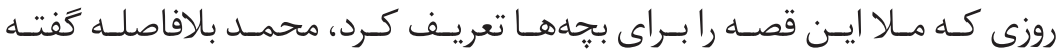
بـود: ـ يـدر موسـى هـم مثـل هـمان مـرد اسـت . بيـن معـدن بـا يتـك سـنَها را خـرد

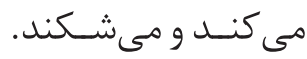

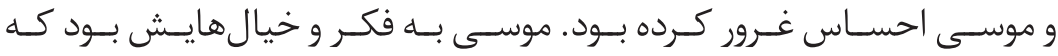




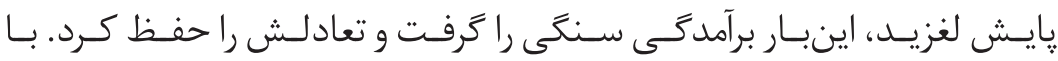

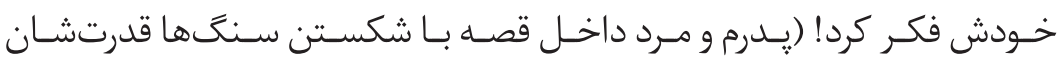

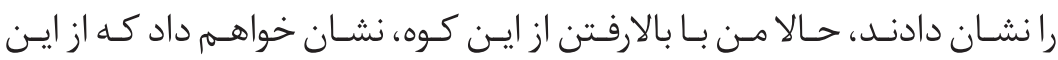
كـوه قوى تـر هسـتم. كمـى ايسـتاد و نفـس تـازه كـرد. دوسـت داشـت بـــ ياييـن نغاهـى بينـدازد، امـا كوجكتريـن حركتـى ممكـن بـود باعـث سـقوطش شـود.

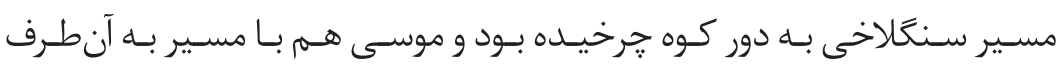

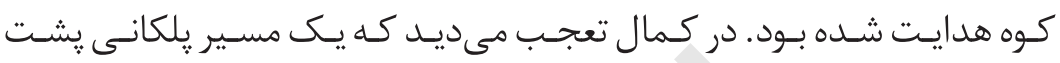

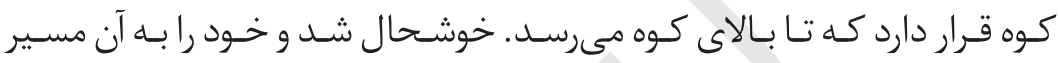

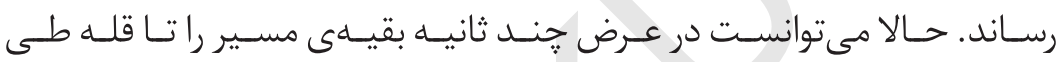

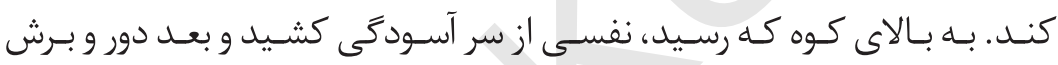
را برانـداز كـرد. ســحح بـالاى كـوه بـدون هيـجه شـيبى، صـاف صـاف بـود. تنـهـا هيـزى كـه آن بـالا وجـود داشـت يـك درخـت تنومندى بود كه شـاخههايش مثـل

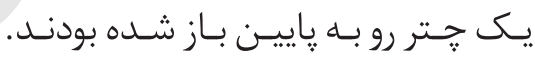

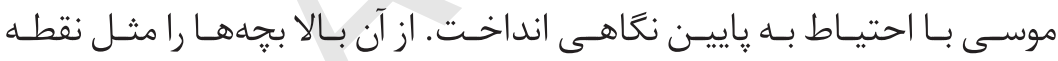

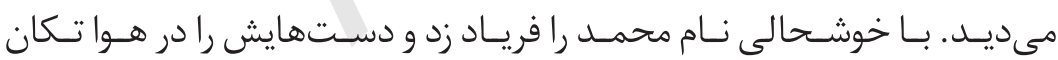
داد.

آن ياييـن محمـد كـه موسـى رانديـده بـود، لـب آب رفتـه و مشـتى آب بـه صـورت

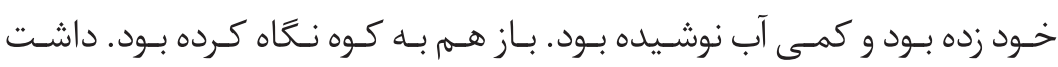

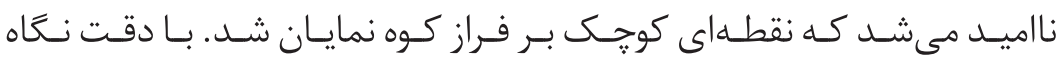

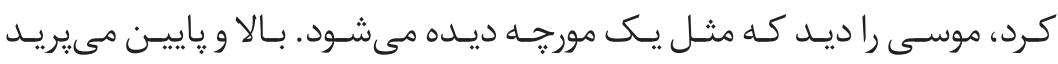




\section{مeزجزى موسى}

و دسـت تـكان مسى داد. محمـد بـا شـادمانى بـالا يريـد و هـر دو دسـتش را در هــوا

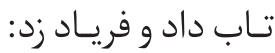

ـ موسى را ديدم، آنجاست. آن بالا... ببينيدش... موسى برنده شد....

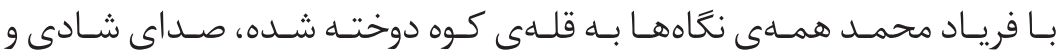

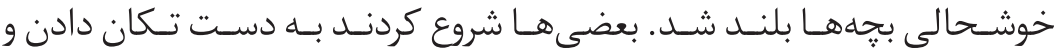

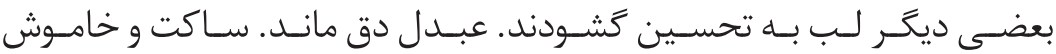

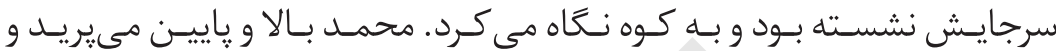

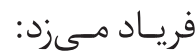

ـ موسـى، موسـى ... و بــا خــود فكـر كـرد (ادعاهايـم مسـتجاب شـد، دوسـتى از دشـمنى قوىتـر اسـت.")

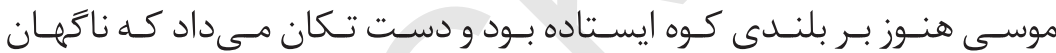

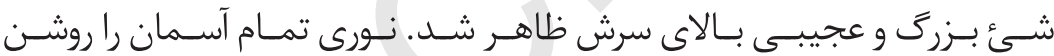

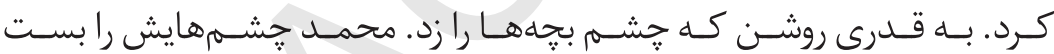

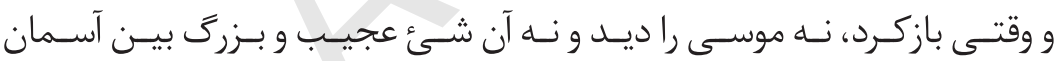

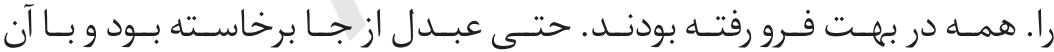

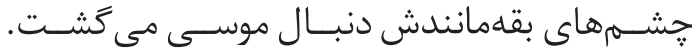

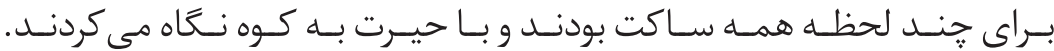

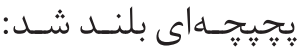
- جى بود آن جيز عجيب؟ ـ موسى جه شد؟ ـ بالاى كوه بود. 


\section{مeجزيز موسى}

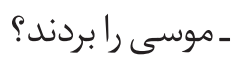
ـ آن شئ عجيب موسى را برد. ـ موسى را بردند.

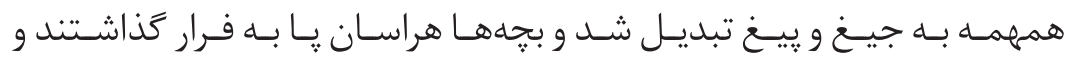

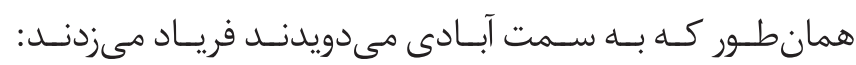
ـ موسى را بردند، موسى را بردند... - مل

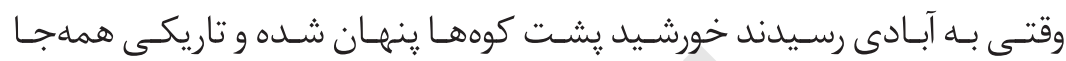

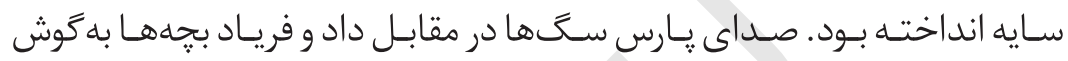

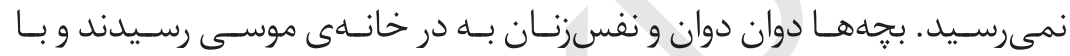
تمـام توانشـان بـه در كوبيدنـد و فريـاد زدنـد: ـ موسى را بردند... آ|||lى لـى مادر موسى... موسى را بردند... 


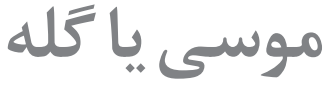

خديجـه خاتـون كنـار دار قالين نشســه بـود و زيــر نـور جـراغ بـه تـارو يـود قالين

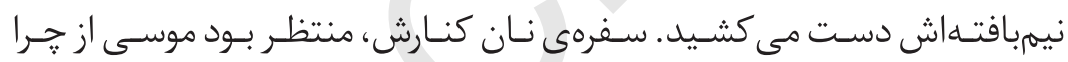

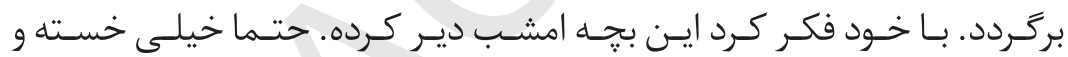
كشـــه شـده. بلنـد شـد و كمى مسـكه بيـن ظرف كوجكى برداشت و ورى سـفره

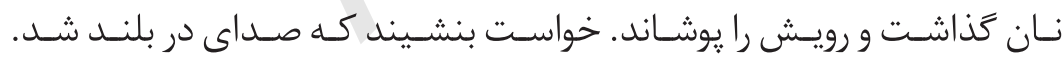

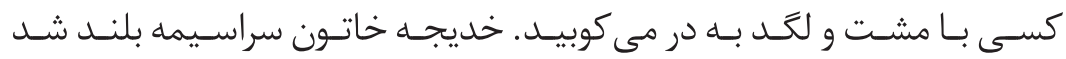

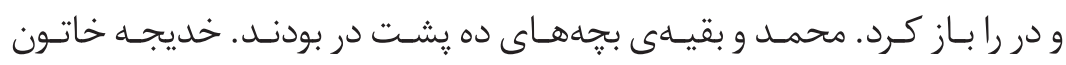

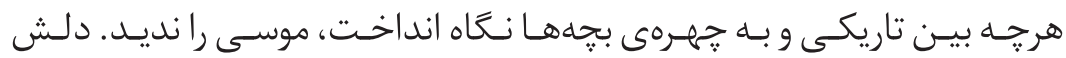

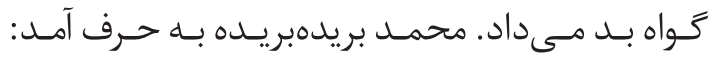
ـ ـ موسى، مادر موسى، موسى، كوه...، بردند، بردند...

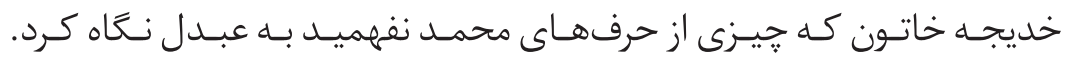




$$
\begin{aligned}
& \text { عبـدل هـم هنـوز نفسنفـس مـىزد: } \\
& \text { ـ موسى، موسى را... بردند.... }
\end{aligned}
$$

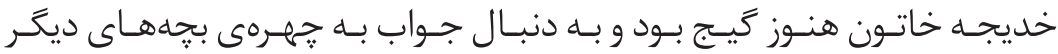

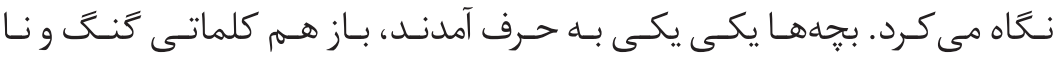
مفهوم:

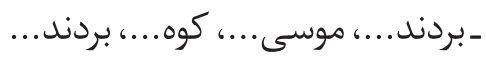

خديجهخاتون كه طاقتش تمام شده بود دستانش را بالا برد و زفت: ـ به لياظ خدا، يكى تان درست گٍ بزند، جه مي گوييد شما؟

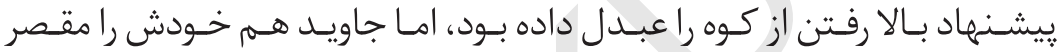

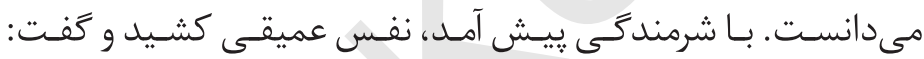
ـ خالهجـان، مـا رفتـهـ بوديـم بركـه شـنا كنيـم. بعـد موسى خواسـت از كـوه بـالا

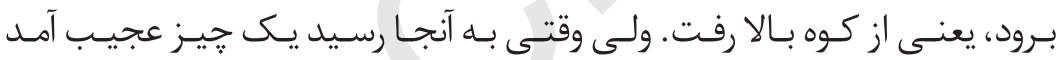

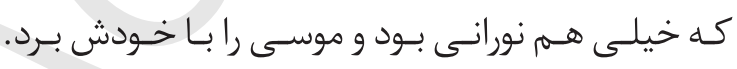

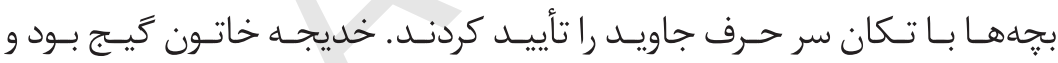

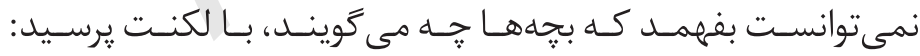

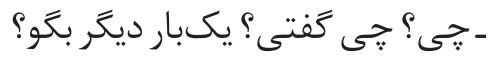

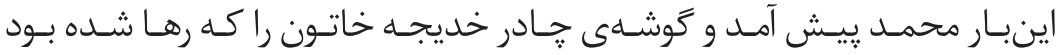
كرفت و گفـت:

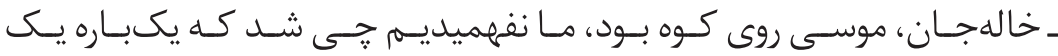

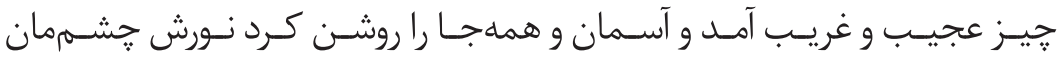

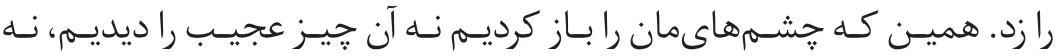


موسسى را.

خديجه خاتون دو دستى زد به سر خودش:

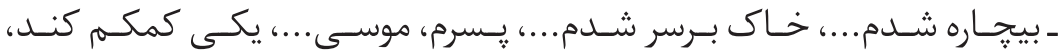

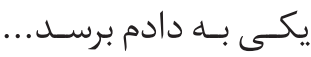

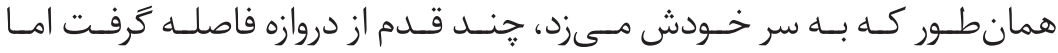
دوبـاره برگشـت، دسـت محمــد را كشـيد و بـهـ طـرف خانسهى همســايهها بـرد.

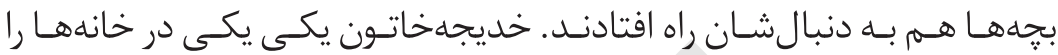
مسىزد و كمك مى خواسـت. كم كسم اهالـى ده از خانههاىشـان بيـرون شـدند

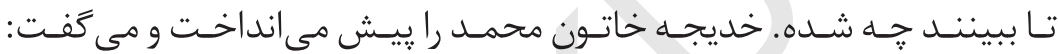
ــبخو، براىشان تعريف كن جه شده.

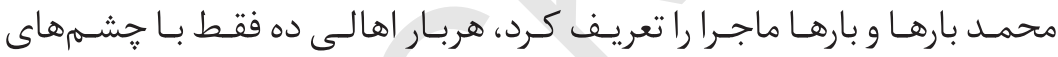

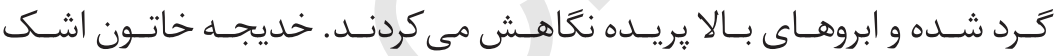

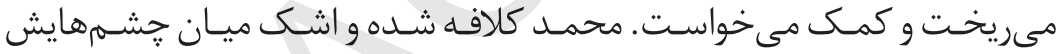

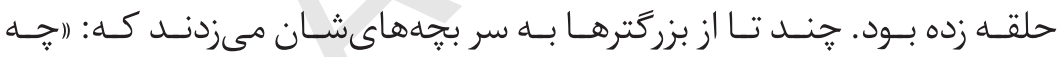
مركَى مى خواسـتيد كـه بـالاى كـوه رفتيـد؟ نَخفتيـد بيفتيـد و بميريـد مـا خــرج كفـن و دفـن از كجـا بياوريـه؟؟ )

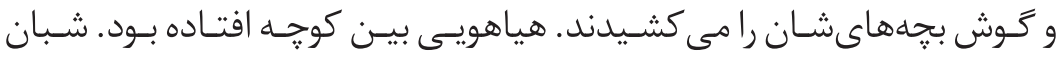

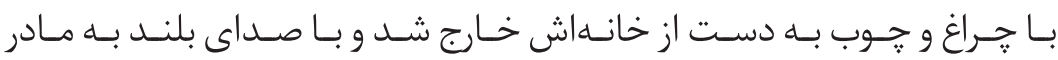
موسسى كفت: ـ نكران نباش خواهر جان. ما مردها بيدايش مى كنيم.

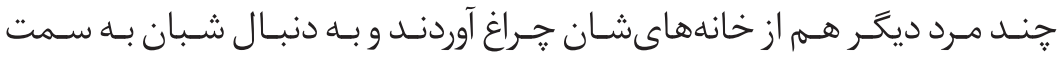




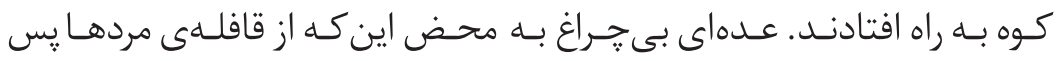

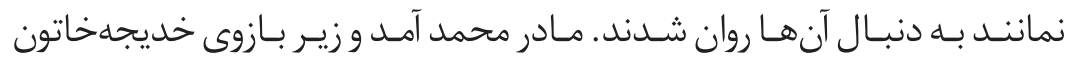

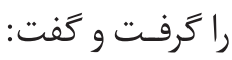

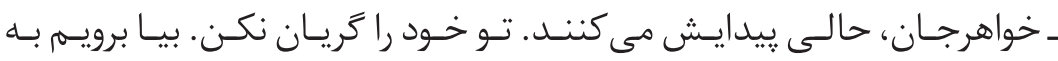

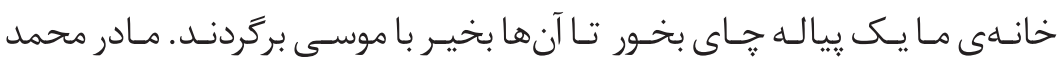

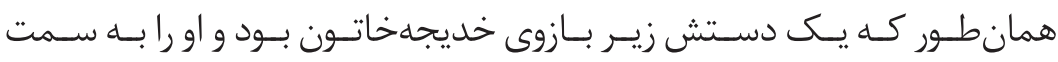

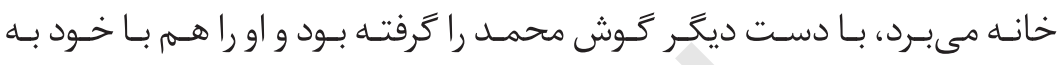

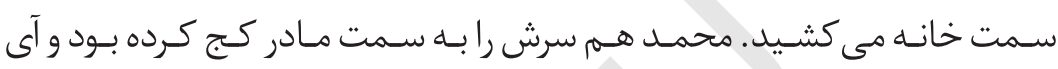

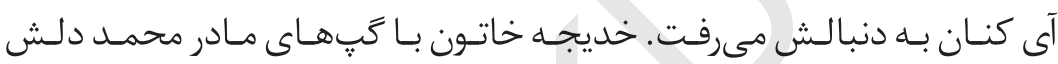

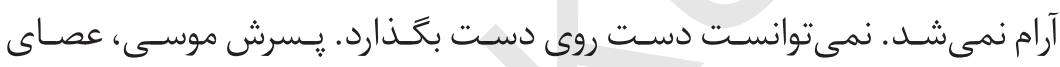

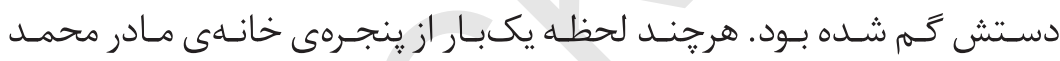

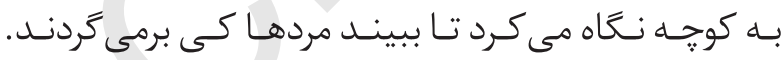
ـ يكدم آرام بكير و اينقدر بالبالك نزن، ييدا خواهد شد. خديجهخاتون همان طور كه نغاهش به بيرون بود كفت: -نمى تموانم. جند نقطهى نورانى را ديد كه از انتهاى كوجهه ييش مى آيند. فرياد زد:

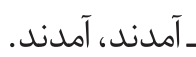

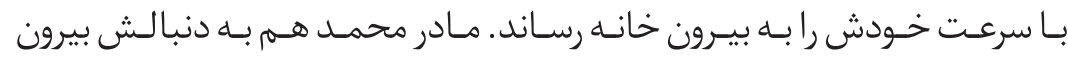

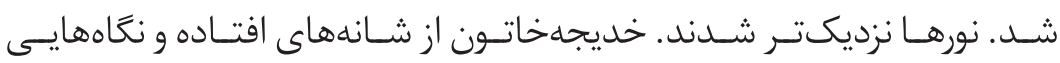
كـه بــه زميـن دوختـه شـده بـود، فهميـد موسـى را يـيـدا نكردهانـد. صـورت مردهــا

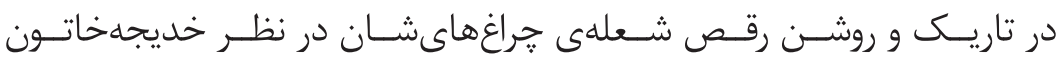




\section{معجزمى موسى}

زشـتـترين صورتهايـى بــود كـهـه در عمــرش مى ديـــ. زيرلـب زمزمــه كــرد:

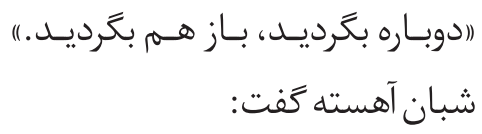

ـ نيست، دود شده و به هوا رفته.

$$
\text { - بازهم بخرديد. }
$$

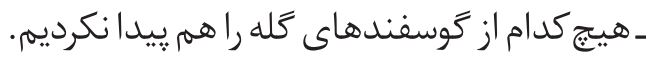
صداى خديجهخاتون به يكباره به هوا رفت:

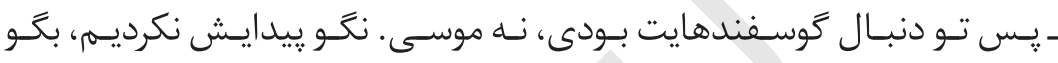
نخَشـتيم. دنبـال گوسـفند بوديـم.

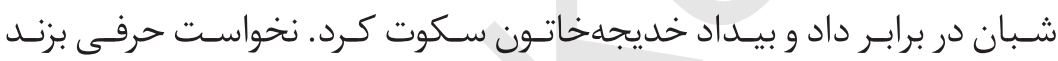

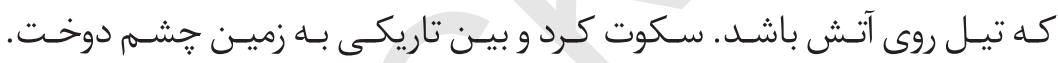

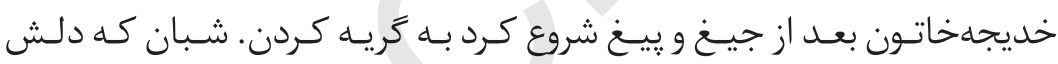
بـه حـال مـادر موسـى مىسـوخت كفـت ـ خورشـيد كـه طلـوع كنـد بازهـم يـى اش مىرويـم خواهرجـان. موسـى هـم جاى بجههـاى خودمـان.

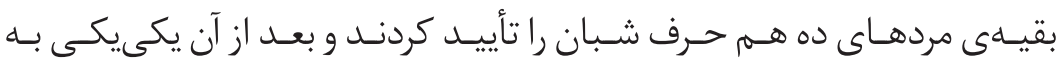

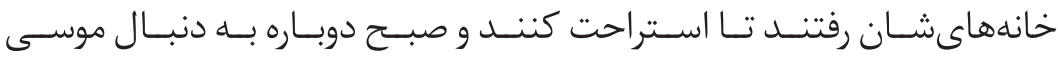
بحردنـد.

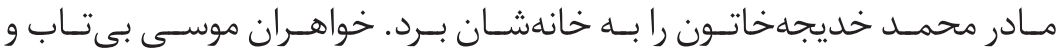
نَــران بيـن رخت خوابهاىشـان نشسته بودنـــ و جـز انتظـار كارى از دستشـان برنمى آمـد. 


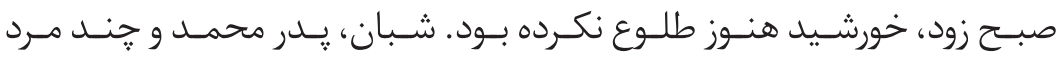

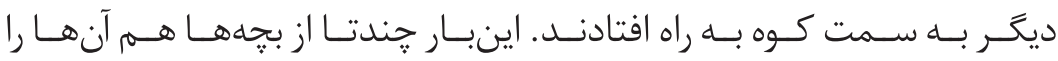

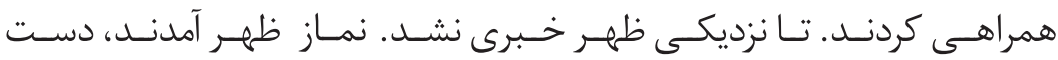

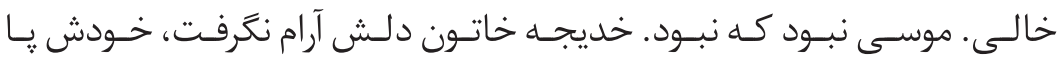
كشـيد بـه سـمت بركـه. مـادر محمـــ و جنـــ زن ديخـر هـم همراهـى اش كردنـد.

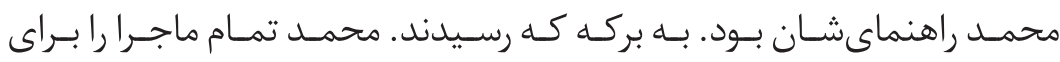

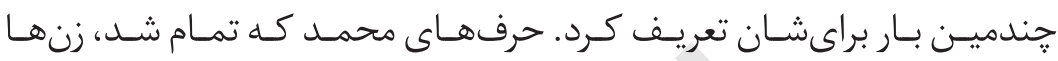

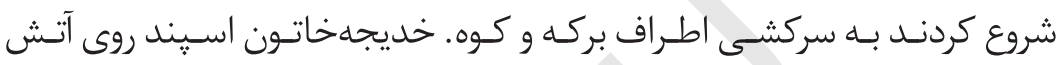

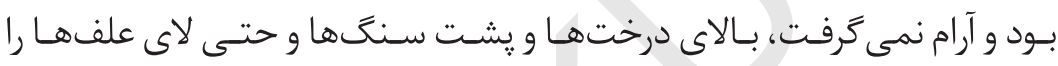

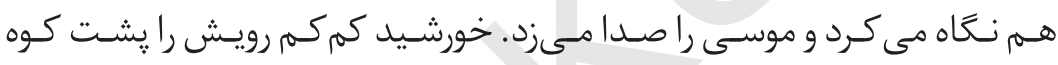

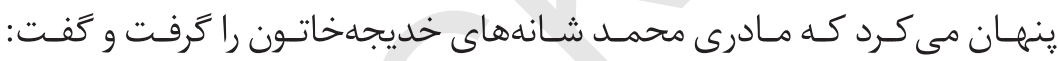

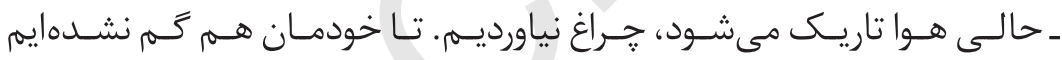

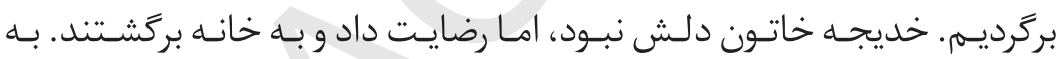
خانـه محبوبـه مـدام دور مـادرش مى جرخيـد، برايـش تجـاى آورد. مـادر غصـهدار بـود و نخـورد. سـفره نـان را آورد، مـادر زفـت كـه سـير اسـت. محبوبـهـ از غـم مـادر

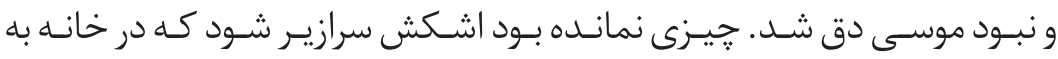
صـدا در آمـد، از جـا يريـد و در را بـاز كرد. مـادر محمــد بـود. داخـل آمـد و كنـار خديجـه خاتـون نشست و دسـت برشـانهاش كذاشـت:

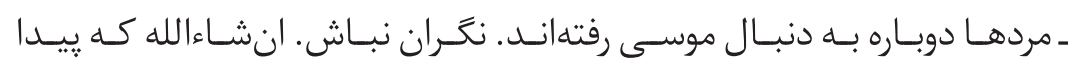
مىشـود. مـادر موسـى دلـش كمسى آرام شـد.

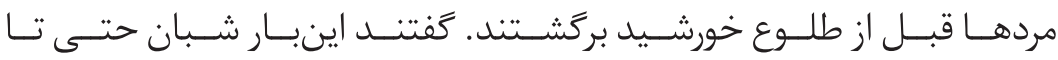




\section{مeزجمى موسىى}

بـالاى كـوه هـم رفتـه امـا اثـرى از موسـى نبـود كـه نبـود. كم كمى همـهـ از يـيـدا

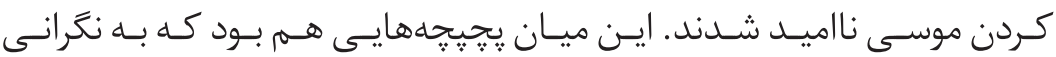
خديجهذخاتـون اضافــه ميى كـرد.

ـ كَلهى شبان هم كم شده و هيج اثرى از آن نيست. كى مقصر است؟ ـ كى تاوانش را ميى دهد؟ سيصد گوسفند كم نيست....

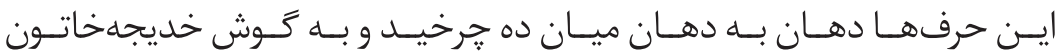
رسـيد. امـا شـبان هـمان شـب بـهـ مـادر موسـى كَفت: ـ اتىر كمم و كسرى داشـتيد يـا كمكى خواسـتيد مـن هـم جـــى برادرتـان، حتـما

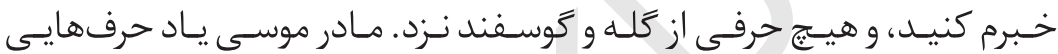
كـه بــه شـبـان زده بـود افتـاد و سرخ شـدـ فقــ توانسـت تشـكر كنـد. ديخَر همـه اميدشـان را براى ييدا شـدن موسـى از دسـت داده بودنـد. خواهرهاى

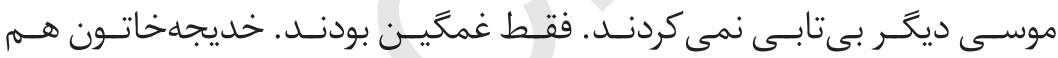
ديخَر رمقـى بــراى گريــه نداشـت، جانمــازش را يهــن كـرد و از خـدا خواسـت يـسرش را برگردانـد.

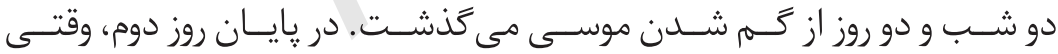
خورشـيد رويسش را يشـت كـوه ينهـان مى كـرد و شـب بـا جــادر سـياهش مى آمـد تـا بـر خانههـا و كـوه و دشـت سـايه انـدازد، مادر روى جائمازش امـن يجيـب... مى خوانـد كـه صـداى ضعيـف بع بـع و سـم كوسـفند شـنـيد. سراسـيمه بلنــد

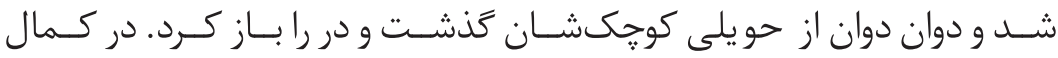

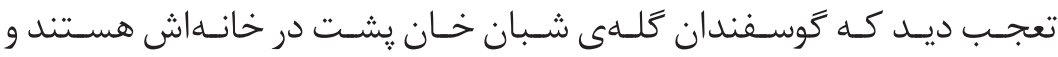
موسـى يشـت در روى زميـن افتـاده. اللـه اكبرى كَفت و دسـتش را روى سـينهاش 


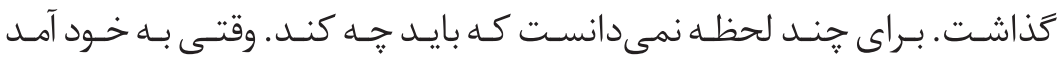
كوسـفندان را يسس زد و زيـر بـازوى موسـى راكرفت و صـدا زد:

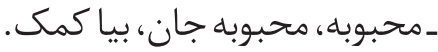
محبوبـه كـه موسـى راد در آن حـال ديـد زد بـه صـورت خـودش. مـادر دوبـاره صـدا زد: -بيا كمك كن.

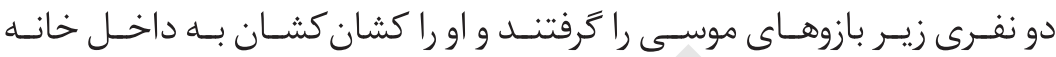

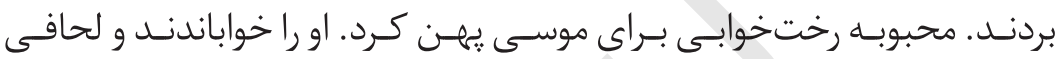
رويسش كشـيدند. مـادر محبوبـهـ را بـهـ دنبـال طبيـب فرسـتاد. خـودش كنـار موسـى نشسـت و او را صـدا زد و تكانسش داد. امـا موسـى نـه جشهـمهايش را بـاز

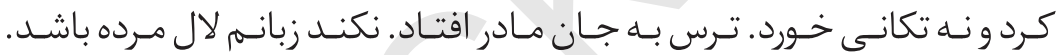

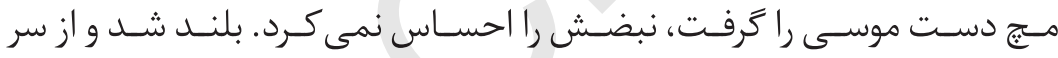

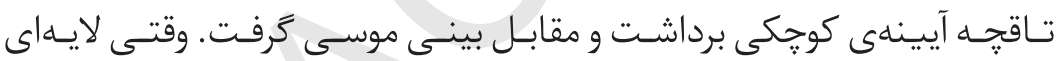
بخـار ســح آيينه را مكدر كـرد خديجهخاتـون نفس راحتى كشـيد و تـا آمـدن طبيـب زيـر لـب امسن يجيـب خوانـد.

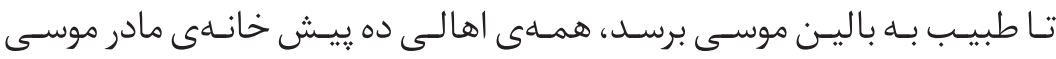

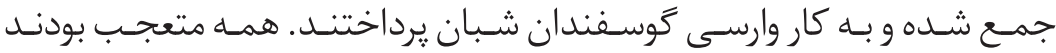
از اين كـه تمـام كوسـفندان بـى كموكاسـت بعـد از دو روز ييداي شـان شـده بــود.

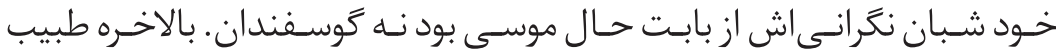

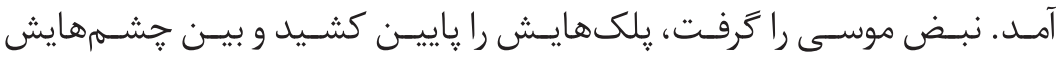

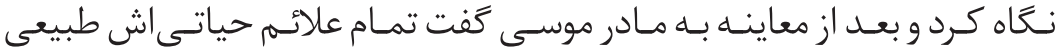




\section{مeزجمى موسىى}

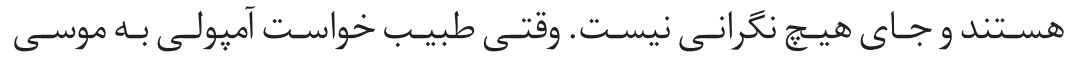

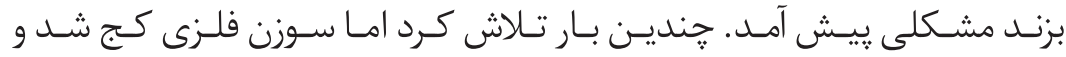
در يوسـت موسـى فـرو نرفت كـه نرفت. انـحار آن را بـه سـنَ زده باشسى. طبيـب متعجسب بـه يوسـت موسـى دسـت كشـيد، نـرم بـود. امـا هرجــه كـرد نتوانسـت سـوزن را بـه بــن او فـرو كنـد. درمانـده شـد و بـه خديجـه خاتـون كَفت: - جيزى نيست، انشا لله كه بيدار مىشود. فقط بايد كمى منتظر بمانيد.

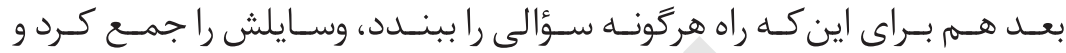

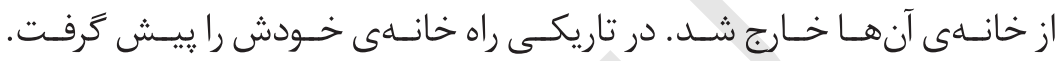

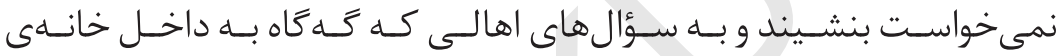

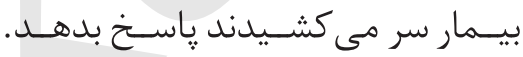
ـ موسى را جه شده؟

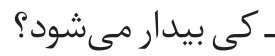

ـتوانستى به او سوزن بزنى؟ - جــه رقـم طبيبــى هسـتـى كـه يـك ســوزن رانمى توانـى در جـان بيـمار فـرو كنـ تقريبـا تمــام اهالـى ده ميــان حويلـى و ييـش خانـهى خديجـه خاتـون جمــع

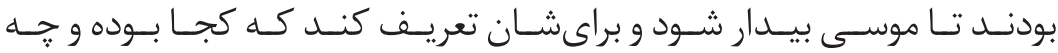
اتفاقىى برايسش افتـاده. طبيـب كـه رفت بقيـهى اهالـى هـم نماندنـد و كم كـم

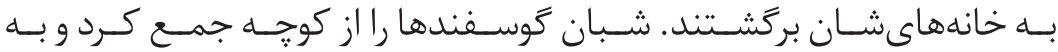
آغل شــان بـرد. محبوبــه بقيـهـى خواهرهايسش را خوابانـد و خــودش بــا خيالـى

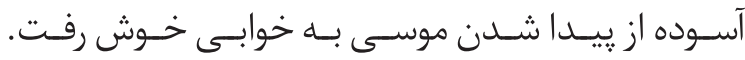




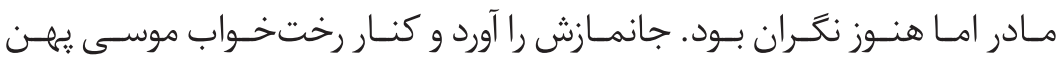
كـرد و تـا صبـح بـالاى سرش ذكـر امنيجيـب خوانـد.

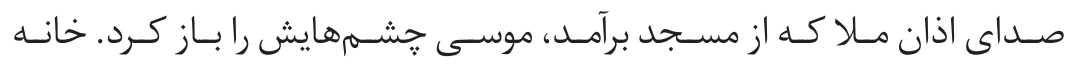

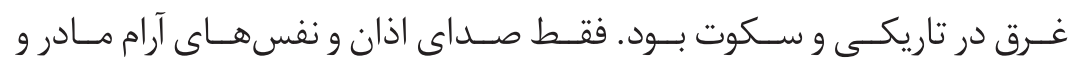
خواهرهايسش بــه تــوش مىرسـيد.

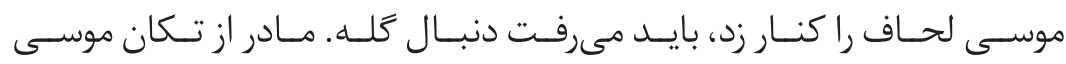
خوابـش ثيريسد.

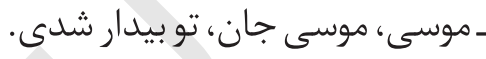

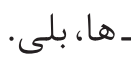
مادر بلافاصله موسى رادر آغوش گرفت و به سر و رويش بوسه زد. - جان مادر. خدا راشكر كه بيدار شدى. موسـى گيـج بـود و نمـى دانسـت ايـن كار مـادر از جـهـ خاطـر اسـت. مـادر بعـد از

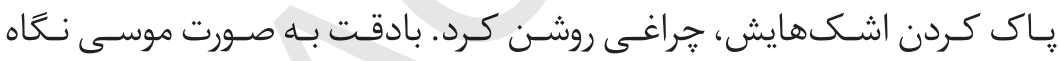

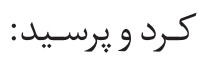
ـ كجا بودى اين دو روز را؟ جه كردى؟ حالت خوب است؟

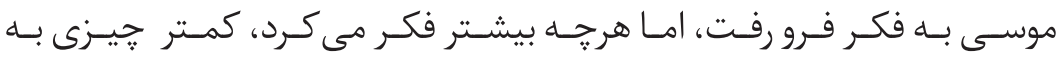

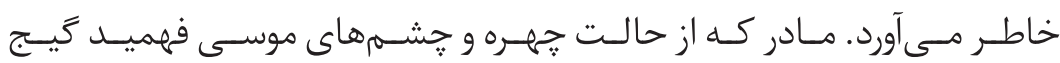

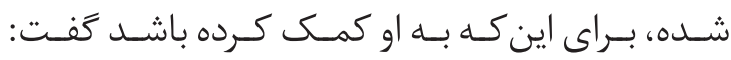

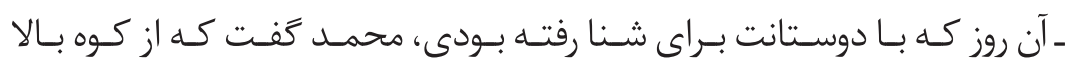
رفتى ... بعـد جــه شـد؟

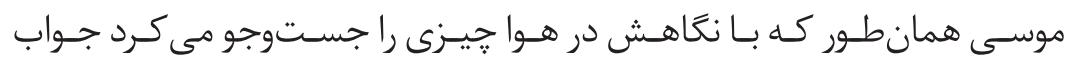


ـ هـا، رفتهم. از كـوه بـالا رفتهم... (حتـى يـادش آمـد كـه در دلـش بـراى عبـدل

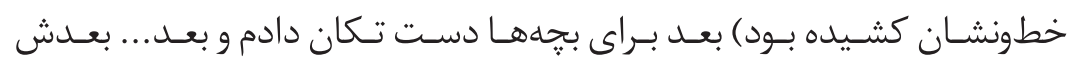
را ديخَر بـه يـاد نـدارم.

هرجه فكر كرد جيزى بيشتر از اين بهياد نياورد. مادر نغران بود:

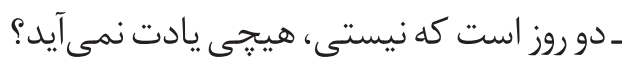
موسى جشمه هايش گرد شد: ـ دو روز؟ نه. - نهيج. موسى از جايش بلند شد. مادر هراسان يرسيد:

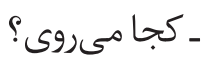

ـ مى مورم يشت كله، ببرمشان جرا. ـ امروز را جايى نرو. استراحت كن. بايد بدانم حالت خوب است يا نه.

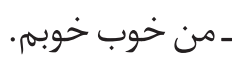

ـوقتى جيزى يادت نمانده، يعنى خوب نيستى. امروز بمان خانه. موسى يس در جايش نشست و به فكر فرو رفت "اين دو روز جه شده؟)"

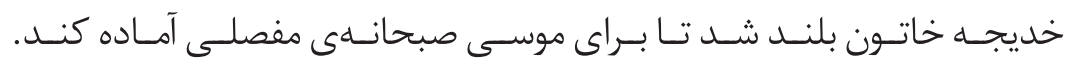

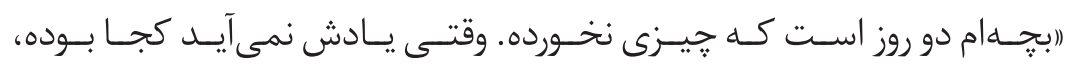
حتـما جيـزى هـم نخــورده. ) 


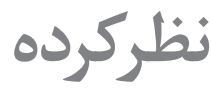

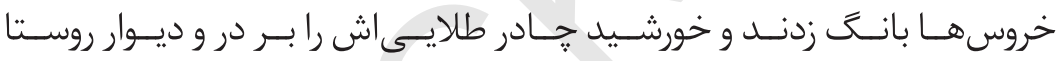

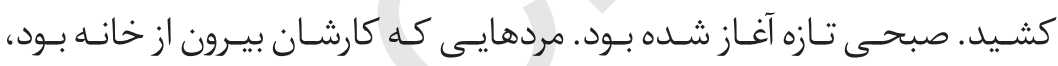

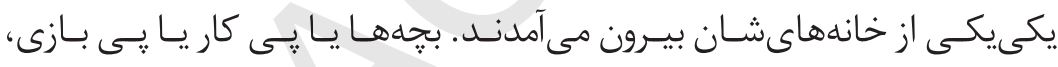

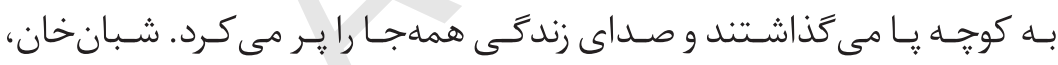

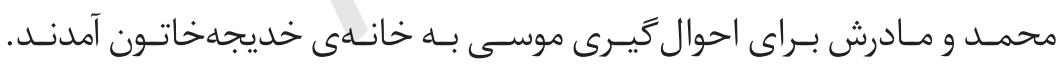

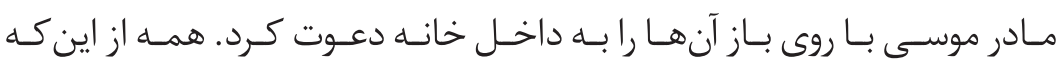

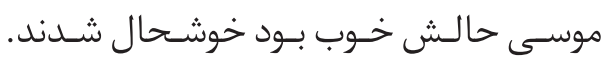
مادر محمد جايش را سركشيد و گفت:

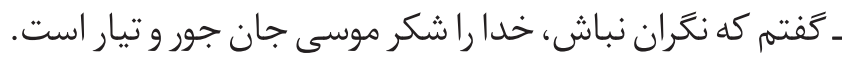

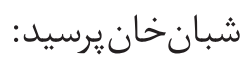
ـ نكَفتى جى شد، اين دو روز كجا بودى موسى؟ 
موسى سرخ شد و كفت:

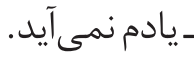

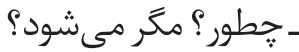

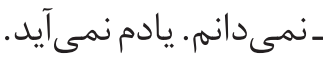

ـ خدا را شكر كه خودت خوب هستى.

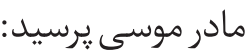

ـ شبان خان شما امروز نرفتيد يشت كله؟

ـ نه، نكران حال موسى بودم. حالا كه خاطرم جمع شد مىروم.

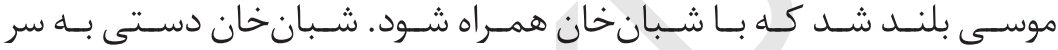
موسـى كشـيد و كفـت

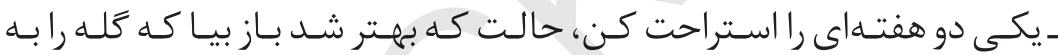

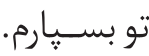
خديجهخاتـون بـه يـاد شـب كَم شـدن موسـى و حرفهايسى كـه بـهـ شـبان خان

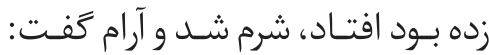

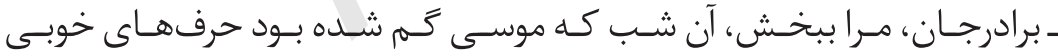
نـزدم.

شبان خان همان طور كه بيرون مىرفت جواب داد:

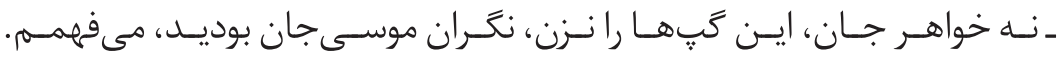

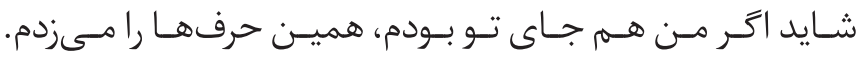
ـ خدا عمرتان بدهد برادر جان. شبان خان كه رفت، محمد به مادر موسى كفت: 
ـ حالا كه موسى يـى كله نمىرود، ما برويم به كوجه يِيش دوستانمان؟ ـ تازه يِيدايش كردم، كجا مى خواهى ببرىاش؟ ننه محمد دومين ييالهى گجايش را هم سركشيد و كفت: ــبخــار برونـد، خـوش باشــد. برويـد امـا مواظب خودتان باشـيد. موسـى و محمد بـا لبخندهايسى كـه تمـام صورتشـان را يوشـانده بـود از خانه بيـرون رفتند.

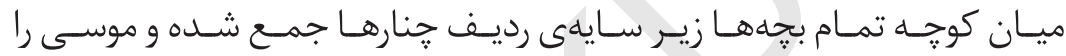
دوره كـرده بودنـد.

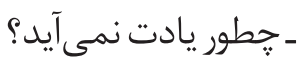
ـيادم نمى آيد ديخر، ج جطور ندارد. ـ دو روز است كه نيستى، مخر مى عـود. ـ حالى كه شده، جه كار كنم. ـ آن بالا جه شكلى بود؟ بالاى كوه را مى گُويم. ـ شكل كوه بود ديگر، فقط سنَ و خاك بود و يك درخت بزرگ. - واقعا جيزى يادت نمى آيد؟ ـ كفتم كه نه.

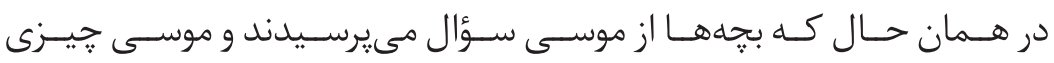

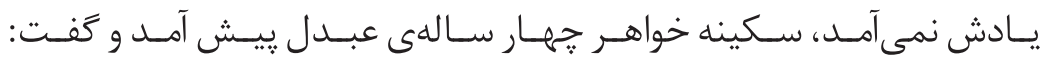
ـ عبدو، عبدو گودى مان بالاى درخت جنار گير كرده، بيا آن راتا كن. 


\section{معجزهى موسى}

عبــل مثـل اين كهـ بخواهـــ يشـهـى مزاحمـى را از خـودش دور كنـد، دسـتش را

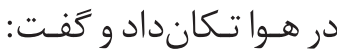
ـ حالى حوصلهات راندارم. برو بعدا مى آيم آن رابرايت تامى كنه. سكينه يايش را به زمين كوبيد و كفت: ـ عبدو، عبدو بيا ديكر.

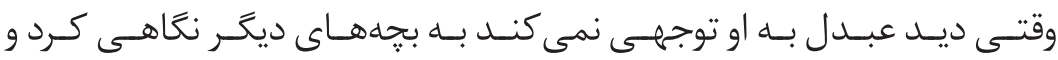
كفـت ـ موسى تو بيا گودى مان راتا كن.

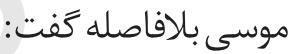

ـ باشـد، برويـم. سـكينه خوشـحال و لى لـى كنــان بـه سـمت درختهايسى كـه

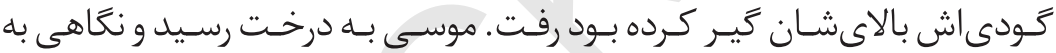

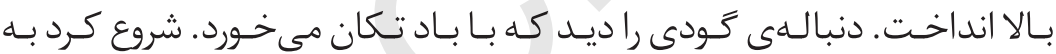
بـالا رفـتن از درخـت و در جشهم برهـم زدنسى آن را گرفت و بــراى سـكينه كـه زيـر درخـت ايسـتاده بـود انداخت. سـكينه آن را در هــوا قاييـد و از موسـى تشـكر كرد و بـا خوشـحالى بـه سـمت دوسـتانش دويـد.

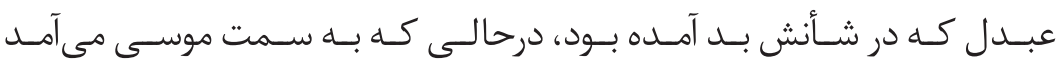

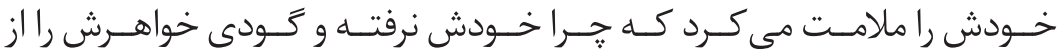

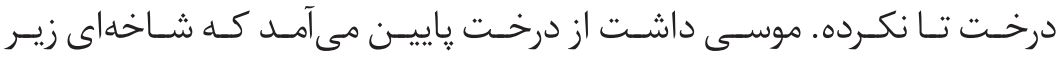

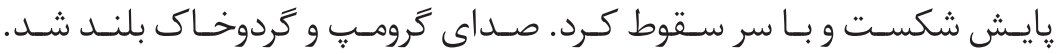




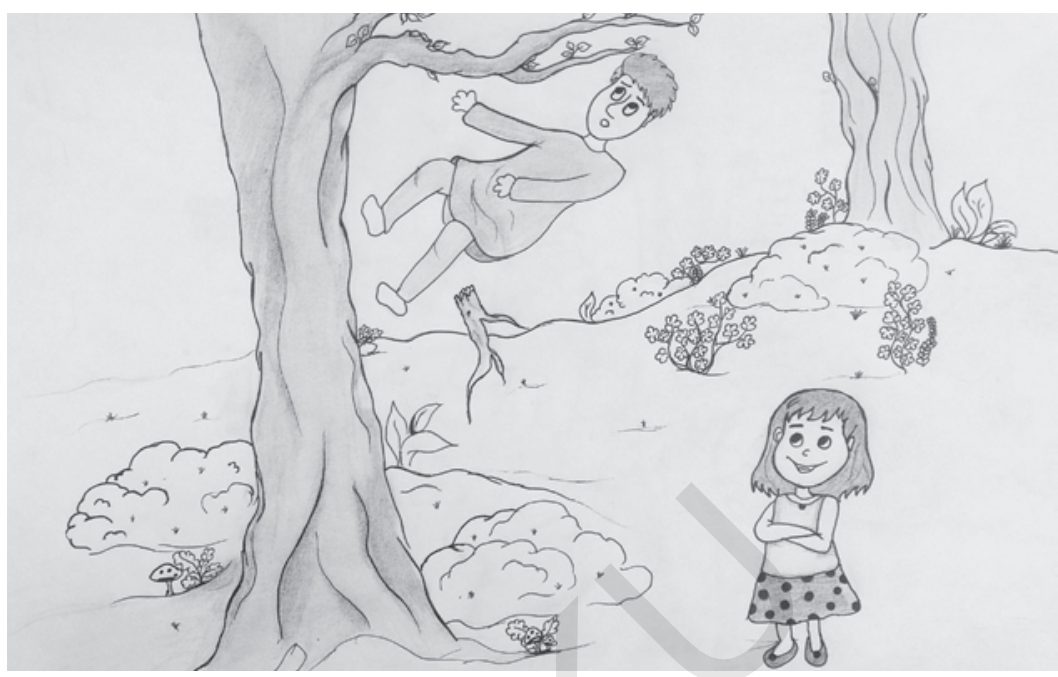

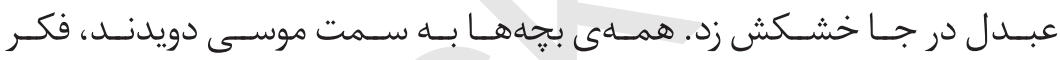

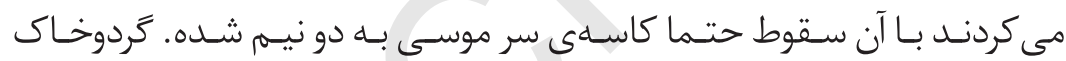

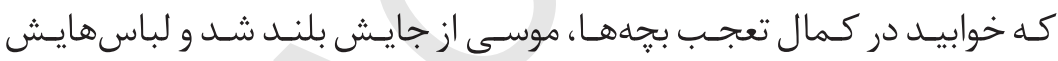
را تكانـد.

$$
\text { - تو حالت خوب است؟ }
$$
ـ او بجه فكر كردم سرت دو شقه شده... -

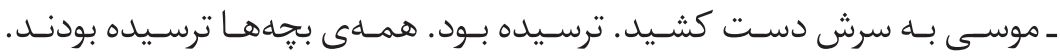

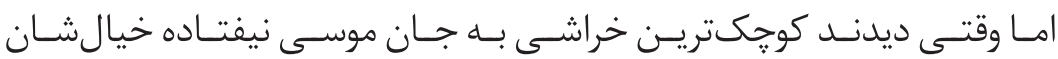
راحـت شـد. ـ موسى تو عجب يسرى هستى، ها... ـ هيتج مركت نشد هى .... 
ـ من اخر از همزهنين ارتفاعى مى افتادم تاحالى مرده بودم بجه.... هركس به شوخى و جدى جيزى مى گفت :

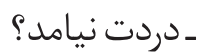

ـ نه، هيج. حالم خوب است. خوب خوب. جور و تيار. باز هم سؤال هاى بجهها دربارهى كوه و آن شئ نورانى شروع شد. ـ موسى واقعا يادت نمى آيد آنجا جه شد؟ ـنفهميدى آن جيز عجيب جه بود؟

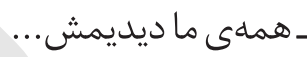

محمــد كـه ديــد موسـى از سـؤال هاى تكــرارى و بـى جــواب كلافـه شــه اسـت، كفـت: -بياييد هفت سنَ بازى كنيم.

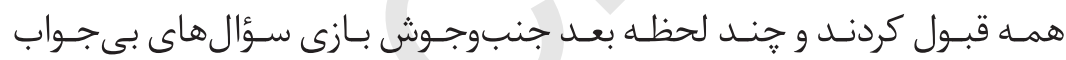

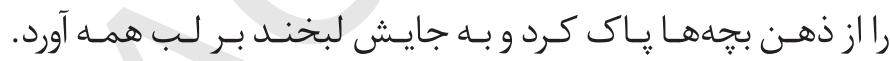

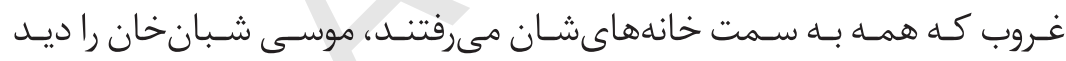

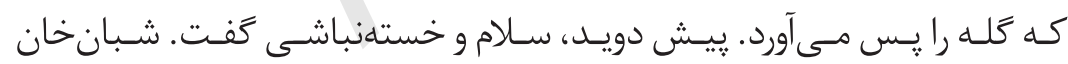

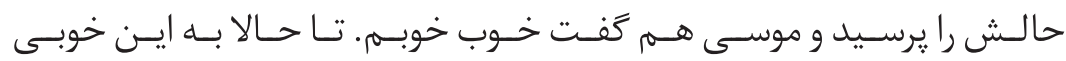
نبـودهام.

موسـى بـه شـبان خان كمك كـرد تا تمـام گوسـفندها وارد طويله بشـوند. دروازمى

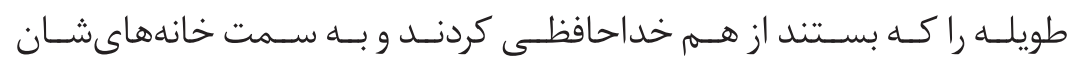
رفتند.

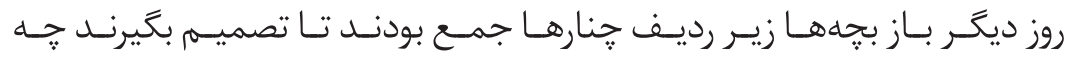




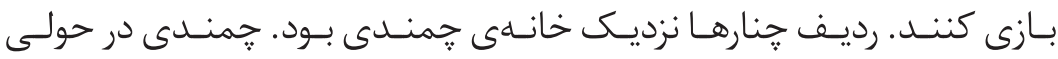

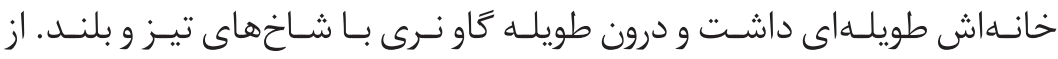

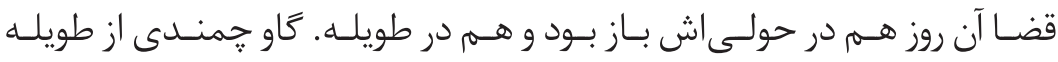

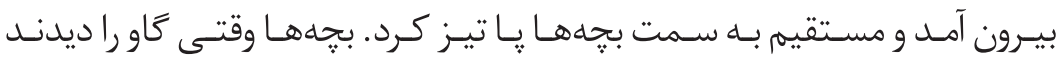

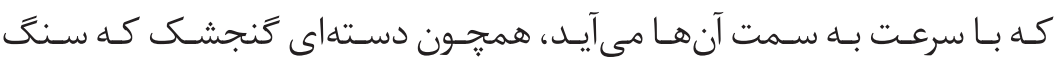

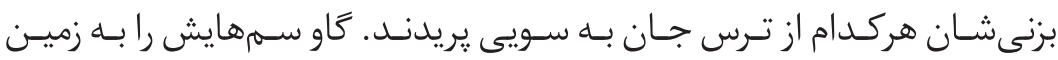

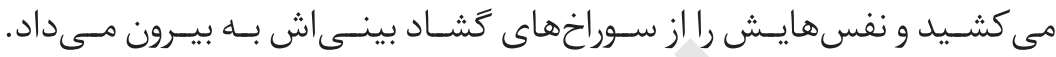

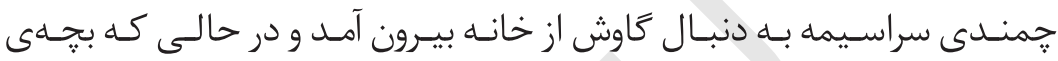

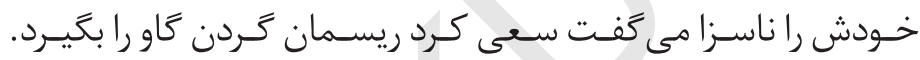

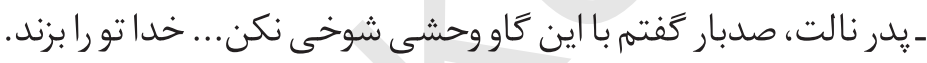

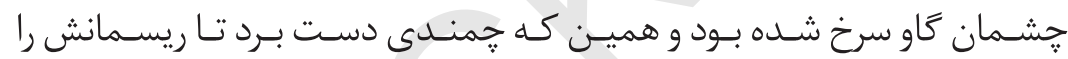

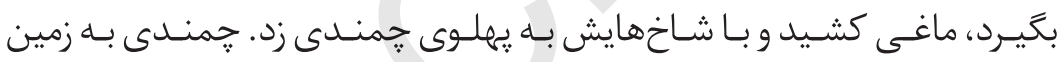

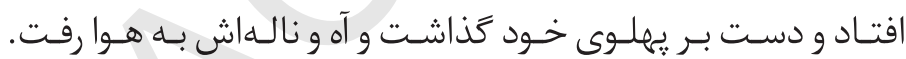

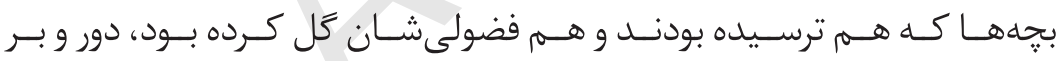

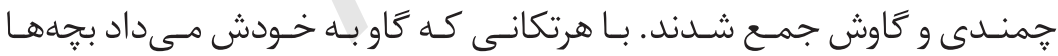

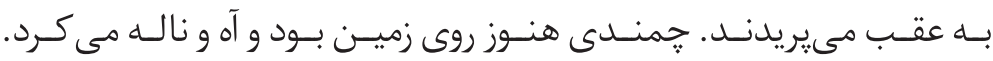

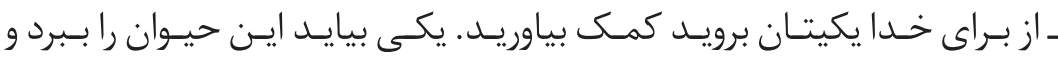
در جايسش ببنـدد.

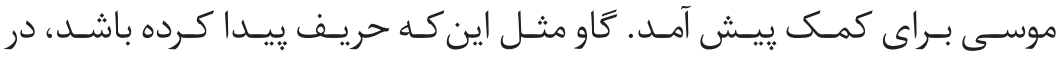

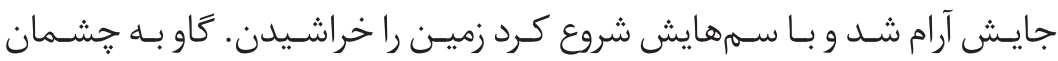

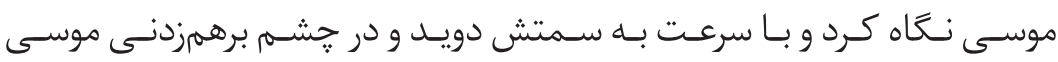




\section{مeزجمى موسىى}

را سر شـاخههايش بــه هــوا يرتــاب كـرد. موسـى شـشى متر آنطرفتـر بـه زميـن

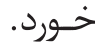

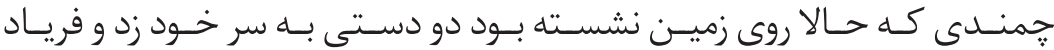
كشــيد: ـ عمر كوتاه كشت، بجهى مردم را كشت، بدبخت شدم. امـا موسـى از جايسش بلنـد شـد، بـدون كوجكتريـن خـراش يـا آسـيبـى. اينبـار

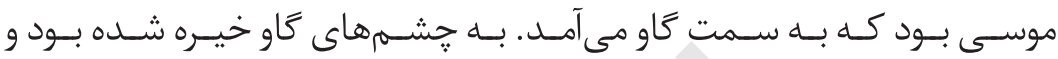

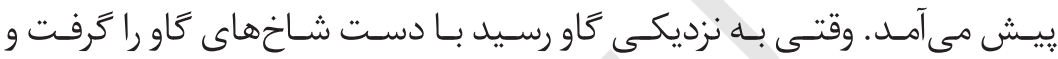

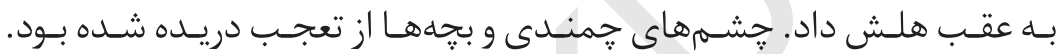
موسـى كاو راعقب عقب هـل داد تـا بـه در طويلـه رسـيد و بـا كمـى فشـار ديخـر بـه شـاخهها او را داخـل طويلـه بـرد. بعـد از جنـد لحظـه موسـى در مقابل جشـمان متعجـب و دهانهـاى بـاز بجههــا از طويلـه بيـرون آمـد و دسـتها و كالاهايسش را تكانـد و كفتـ: بسـتم.

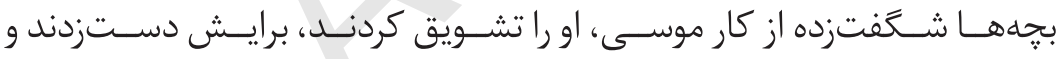

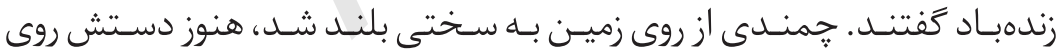
يهلويسش بـود، بـه سـمت موسـى آمـد و بريدهبريـده كفـت:

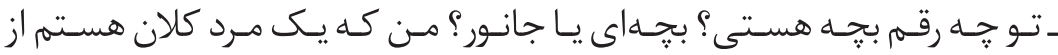

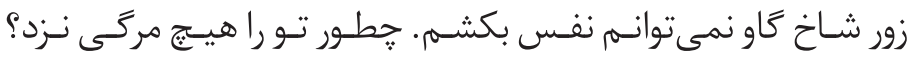

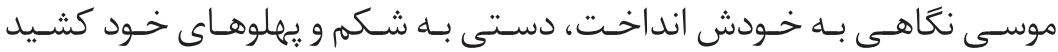
و كفت ـنمى دانم. 


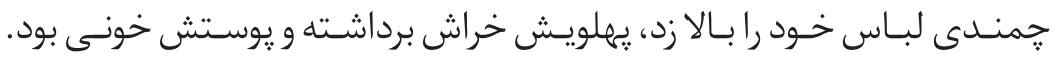
دوبـاره بـه موسـى نــاه كرد: - تو جه رقم بجه هستى يكى از بجه توا كفت:

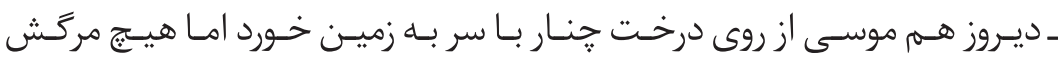

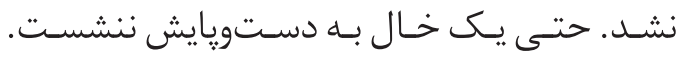

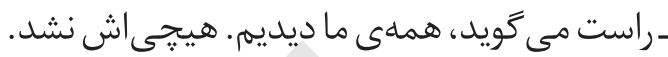
ـ مـن فكـر كـردم حتـما سرش از وسـط شـكافته شـده ولـى مثـل امـروز وقتـى از

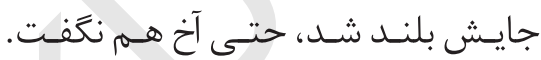

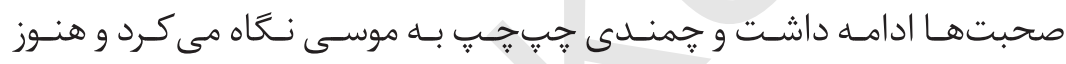

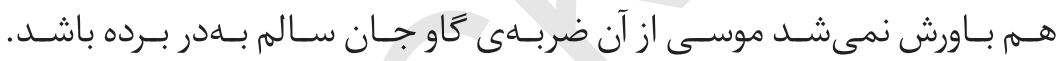
دسـتى بــه شـانهى موسـى زد و كفــت ـ آفرين، خوبش... شيرى كه خوردى حلالت.

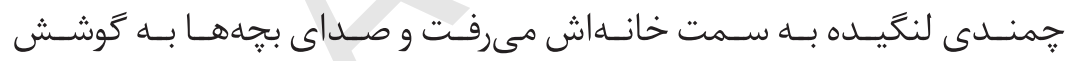

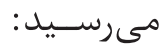
ـ موسى واقعا حالت خوب است؟ - بلى. تا بهحال به اين خوبى نبودهام.

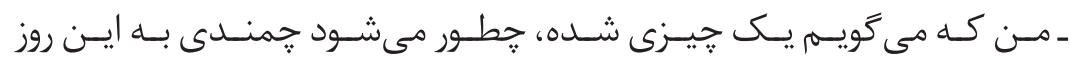
دربيايـد و آنوقت تـو هيـجـ مركَت نشـود. ـ هرجه كه هست جيز خوبى است.

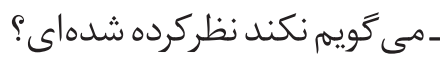


معجزمى موسى

ـ من هم مى خواهم نظركرده باشم. ـ هرجه هست جيز خوبى است.

VV 


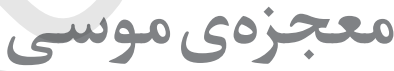

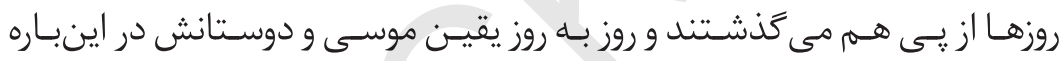

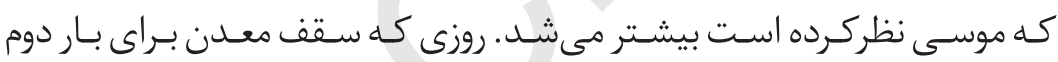

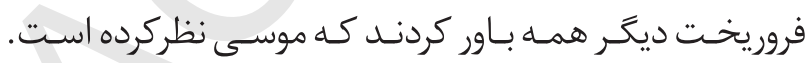

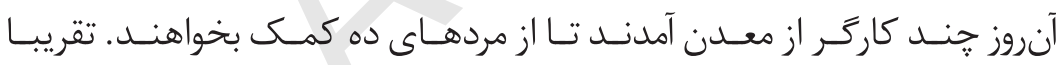

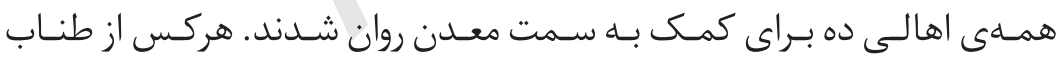

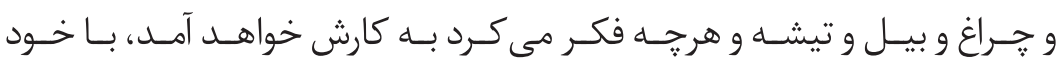
برداشت.

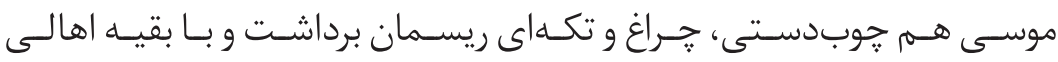

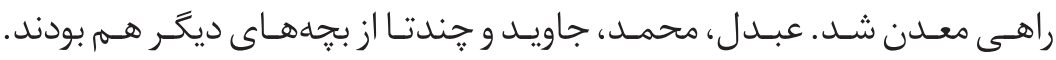

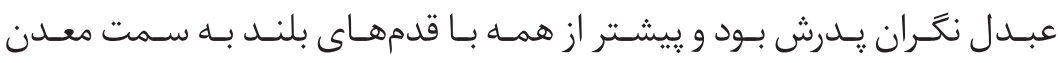

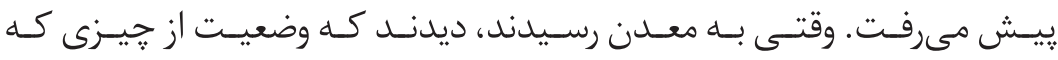




\section{مeزجمى موسىى}

فكـر مى كردنـد بدتـر اسـت. تمــام ورودى از سـنَت يــر شـده بـود. مردهــا قبـل

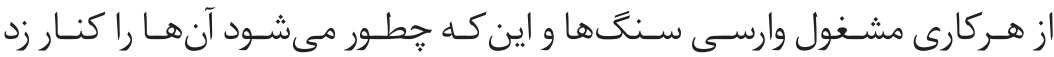
شـدند. ورودى معـدن بــه انـدازماى بـاز بـود كـه هيجيـكـ از مردهــا نمى توانسـت از آن عبـور كنـد. يكىى بايسـ از آن سـوراخ عبـور مى كـرد و وضعيـت داخـل را بـراى

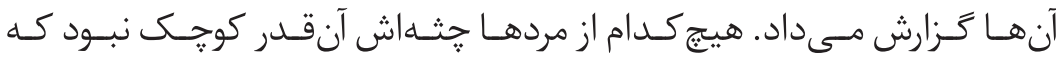
بتوانـد از ميـان حفـرام كـه وجـود داشـت عبـور كنـد. ـ مى توانيم يكى از بجهما را بفرستيم. ـآنها نمى فهمند جكار كنند.

ـ فهـهم نمى خواهـد، فقـط از آن ورودى داخـل شـود و ببينـد سـنَ ها را تـا كجـا بسـتهاند. شـايد آنقـدر هـم كـه فكـر مى كنيـم زيـاد نباشـند. ـ خطرناك است.

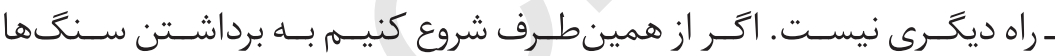

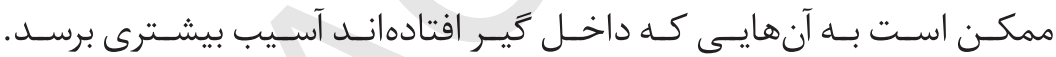
ـ كدامشان رابفرستيم؟ ـ هركدام دل و جرأتش را داشت. يدر محمد رو كرد به بجهها و گفت: ـ مى خواهيـم كـه يـك نفــر از شـما كمكمـان كنـد و از ايـن سـوراخ وارد معـدن شـود. ببينــد تـا كجـا سـقف ريـزش كـرده. ببينـد آنهايسى كه داخـل معـدن كيـر

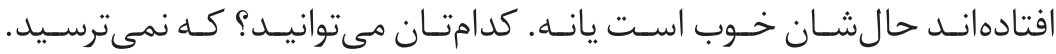
بجهإ به هم نعَاه كردند. عبدل ييش آمد: ـ من مى روم و از يدرم خبر مهى گيرم. 


\section{مeجزيز موسى}

يدر محمد نگاهى به قدوبالاى عبدل انداخت و گفت:

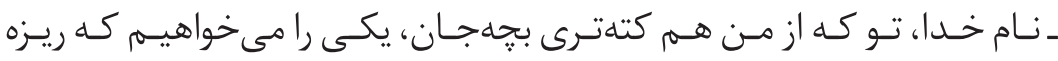

باشد.

موسى يك قدم به يیش برداشت و كفت:

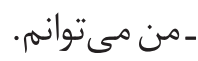

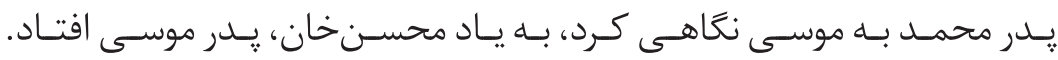

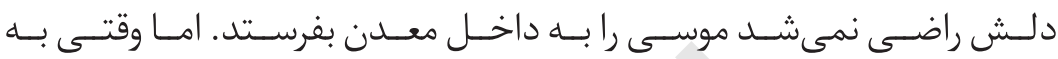

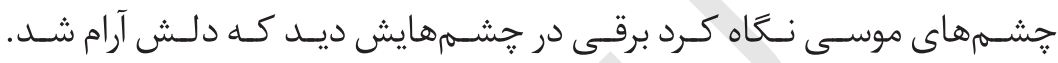

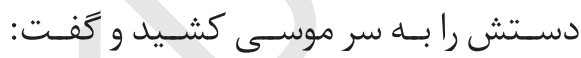
ـبيا بجهام. بيا برو. خدا يشت و يناهت.

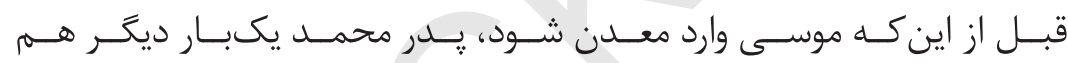
توصيههــاى لازم را بـهـ او كـرد:

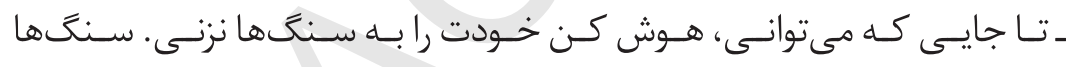
را تـكان نـده. فقـط تـا جايسى كه راه بـاز بـود يـيـش بـرو و خـوب سـيل كـن يـدر

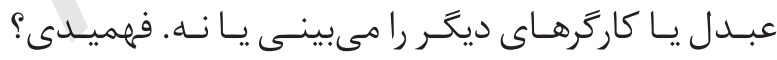

$$
\begin{aligned}
& \text { موسى محكم جواب داد: }
\end{aligned}
$$

ـ هـا بلـى. فهميـدم. بعـد هـم جراغـش را برداشـت و بــا احتيـاط وارد معـدن شـد.

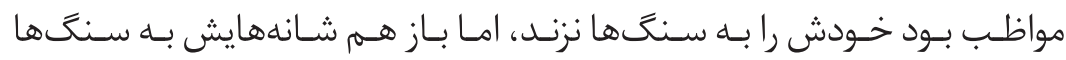

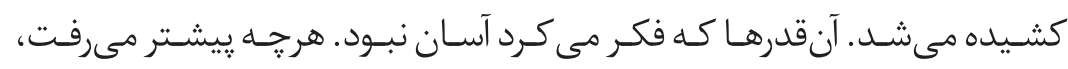

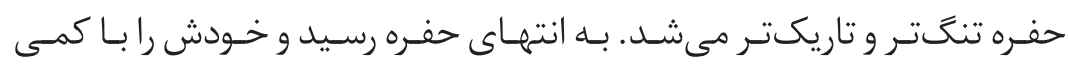

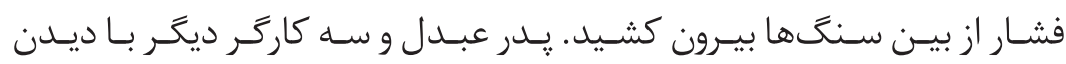




\section{مeزجمى موسىى}

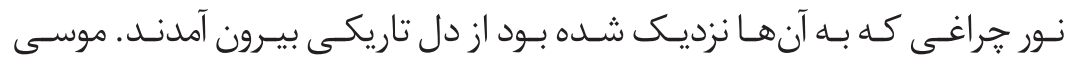
ييشـتر آمـد و در نـور جــراغ آنهـا را ديـد و يرسـيد:

ـ حالتان خوب است؟ مردان يكه خوردند:

ـ موسى تو هستى ؟ جطور آمدى؟ موسى زجراغ را بالاتر گرفت و گفت:

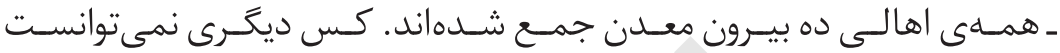
داخـل بيايـد. مـن آمـدم ببينـمم تـا كجـا سـقف ريـزش كـرده.

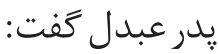

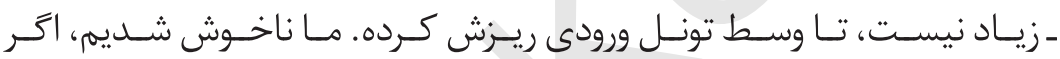

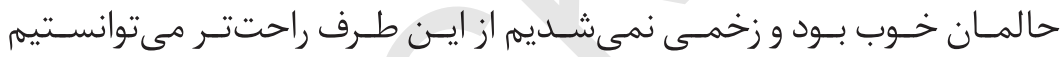
سـنَتها را برداريسم و راه را بـاز; كنيـم.

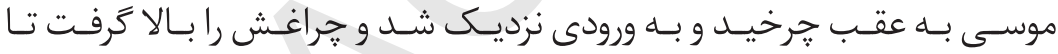
بهـتر ببينـد:

- بياييد شروع كنيم. بايد زودتر برويم بيرون. يدر عبدل لنغَ لنَان ييش آمد:

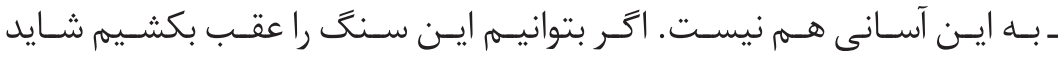

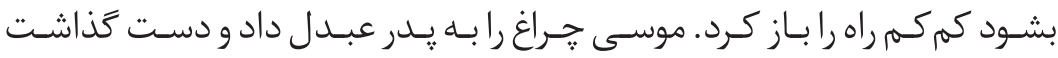
روى سـنَى كـه او بـه آن اشـاره كـرده بـود. بـا يـك حركت آن راعقب كشـيد. يدر عبـدل خواسـت بحويد:

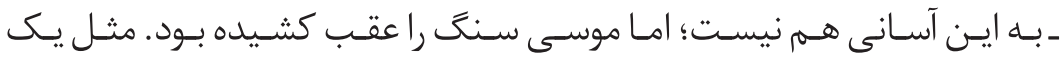




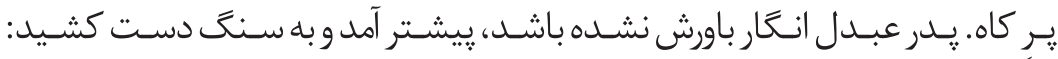

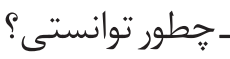
ـنمى دانم، فقط مى دانم كه بايد از اينجا بيرون شويم.

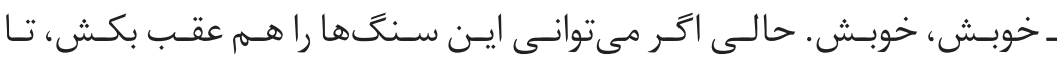
مـن ايسن تيـرك رازيـر سـقف بــذارم.

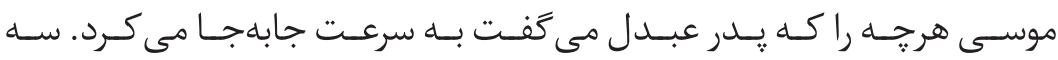

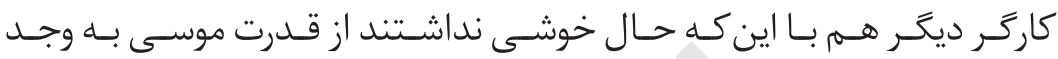

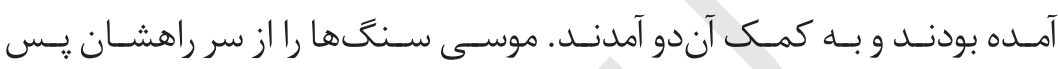

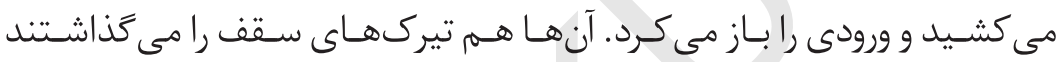

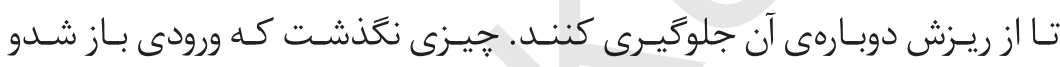

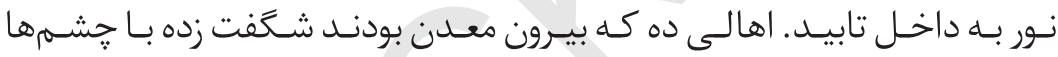

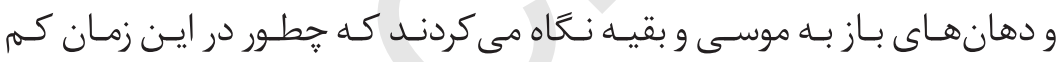

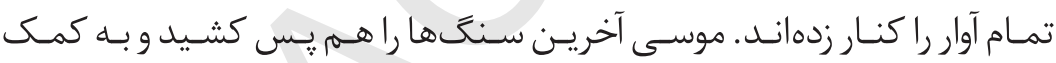

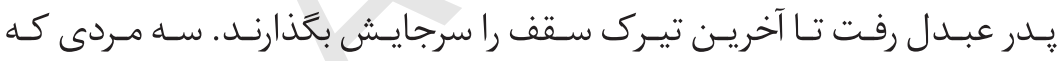

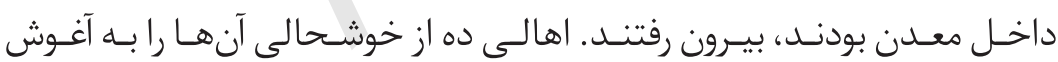

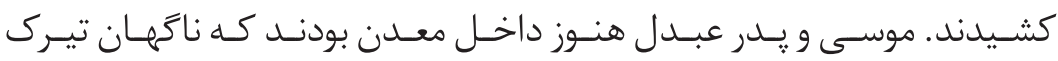

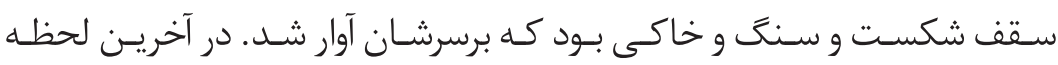

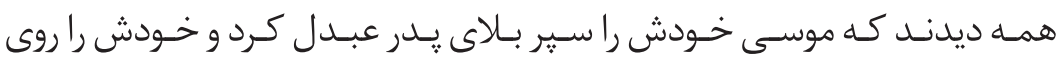

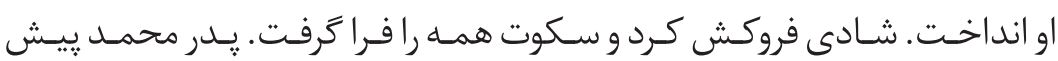
دويـد و كفت: - بياييد، ييش شويد و كمك كنيد. 


\section{مeزجزى موسىى}

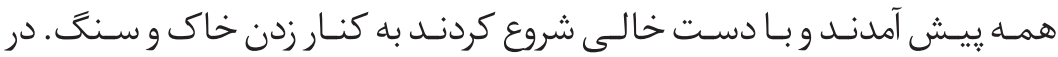

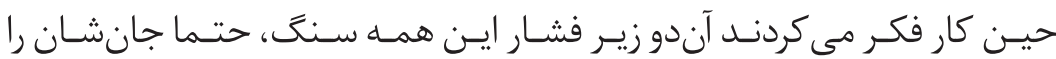

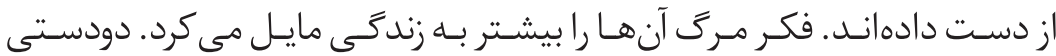

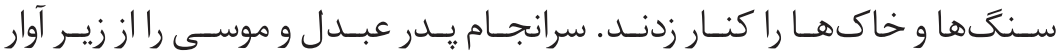

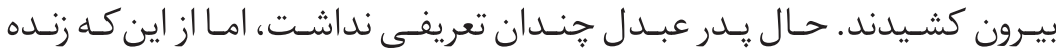

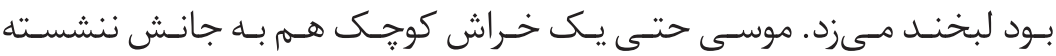
بـود. بلنـد شـد، خـاك مـو و كالايـش را تكانـد.

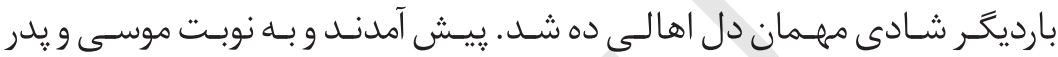
عبـدل را بـه آغـوش كشـيدند و هركدام جيـزى كفتند: ـ شكر خدا كه سالم و زنده هستيد. ـ موسى تو جان آنها رانجات دادى. ـ آفرين موسى، آفرين.

ـ بجهها كفتند تو نظركردهاى، اما ما باورمان نمى شد، احسنت.

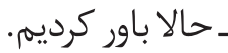
ـ خوبش، خوبش.

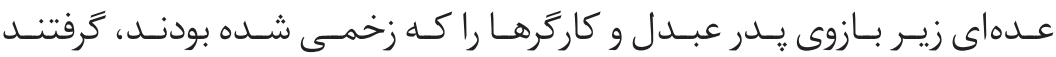

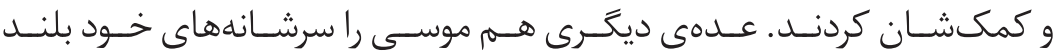
كردنـد و برايـش هــورا كشـيدند: ـ آفرين موسى، آفرين. ـ شير شرزده موسى. ـ احسنت موسى. 
معجزمى موسى

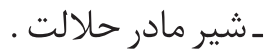

عبدل همم ميان جمعيت بود و موسى را تشويق مى كرد.

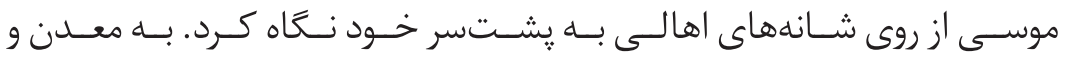

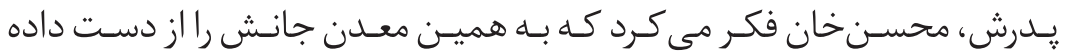
بـود. بـا خـودش فكـر كـرد مـن معسدن راشكسـت دادم. همان طـور كـه كـوه را

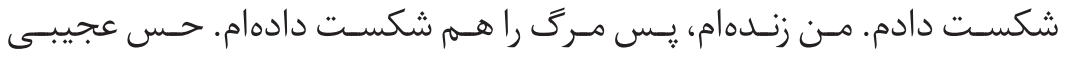

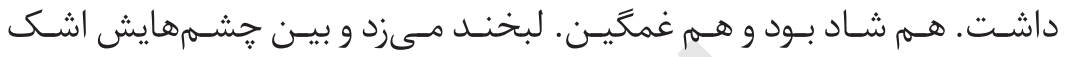

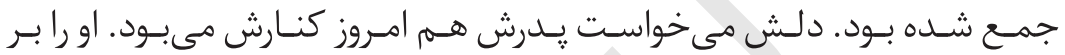

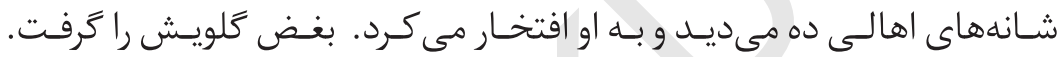

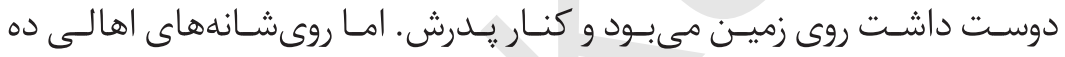

بــه سـمت خانسه يِيـش مىرفت.

$\Delta r$ 


\section{مثل دزدها}

بعـد از ماجـراى معـدن، همـهى اهالـى ده بــه اين يقين رسـيدند كه موسـى يسرى

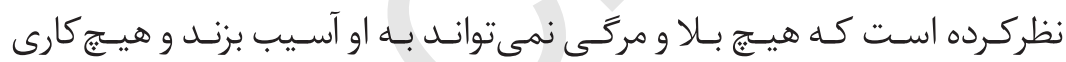
نيسـت كـه موسـى از يـس انجـام دادنـش برنيايـد. بــهـ همين خاطـر هرزمـان كـهـ

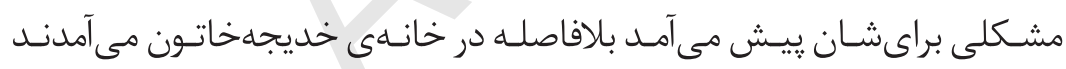

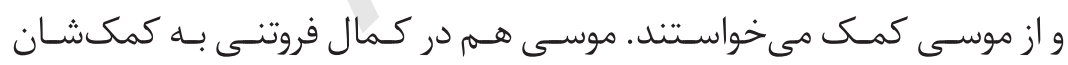
مىرفت و مشكلشـان را حـل مى كـرد. امـا خيلـى نحذشـت كـه ايسن كمكهــا رنت وظيفـه گرفت.

روزى كـه بجــهى يكى از اهالـى بيـن آب افتـاد، موسـى شـيرجهاي زد و او را از آب

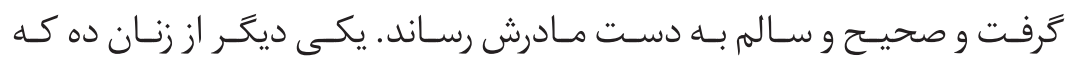
آنجــا بـود، بــه موسـى كفـت 


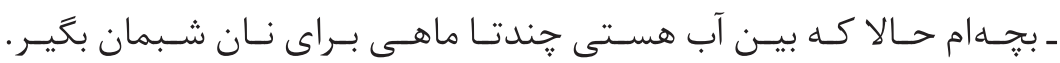

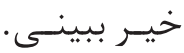

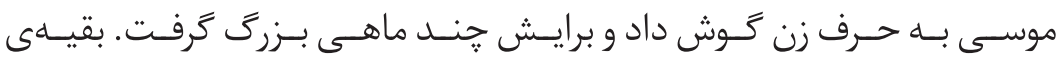

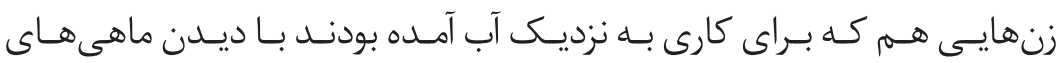

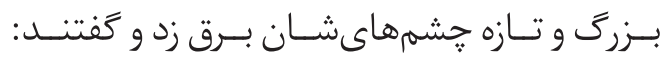
- براى ما هم بخير، خير ببينى بجهام، براى نان شب ماهم بخير. موسـى از ظهـر تـا غـروب بـراى اهالى ده ماهـى گرفتـ شـب بـوى هيزم سـوخته و ماهـى كبـاب شـده در تمـام ده بـه مشـام مىرسـيد. تـا جنــد روز كار موسـى از صبـح تـا شـب زرفـتن ماهـى بـراى اهالـى ده بـود. آنققدر ماهـى گرفت كـه ديكر

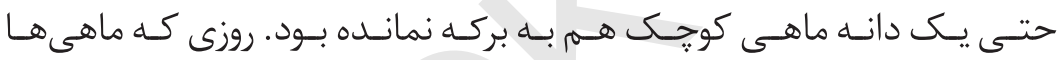

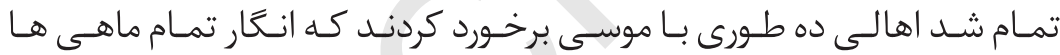
را موسـى بـه تنهايسى خـورده. - جطور آن همه ماهى دو روزه تمام شد؟

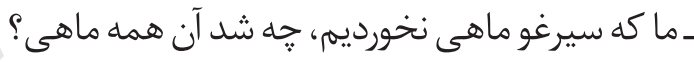
ـ خيرت به مانرسيد. ـ تو هم دستت بى خير است يسر جان.

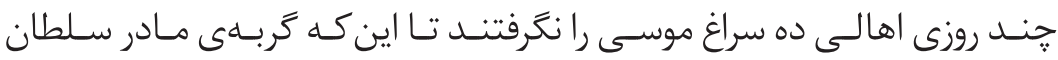

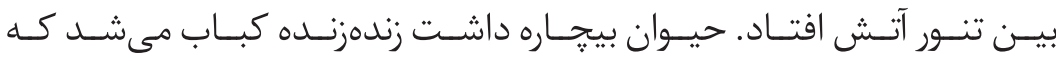
مادرسـلطان بـه خانـهى خديجه خاتـون آمـد و كفــت ـ موسـى جـان، موسـى جـان، دسـتم بــه دامانـت، بيـا و ايـن حيوانـك زبــان بســه 
رانجـات بـده.

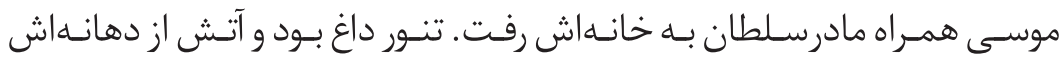
زبانسه مى كشـيد. بـوى مـوى سـوخته تمـامحويلى رايركـرده بـود و صـداى نالـه و

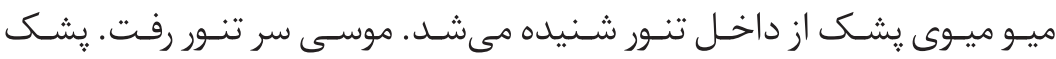

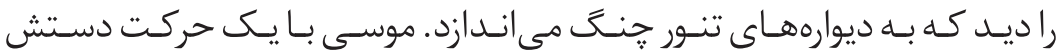
را داخـل تنـور بـرد و حيـوان زبـان بسـته را از ميـان دود و آتـش بيـرون آورد. و بيـن حويلى رهايش كرد. مـادر سـلطان بـا لبخنـد از موسـى تشكر كـرد: ـ اى جان مادر، دستت درد نكند. خير ببينى، دستت كه نسوخت، ها؟ موسى لبخند زد و به دستش نگاهى كرد:

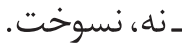
او حتى حرارت زياد آتش را هم حسى نكرده بود. ـ خوبـش، خوبـش، نظركـردهاى تـو بجـــام. حـالا كـه دسـتـت نسـوخته هـمان نانهـاى مـرا كـه بيـن تنـور افتـاده بيـرون بيـاور. خيـر ببينـى.

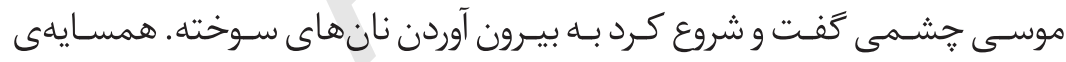
مـادر سـلطان كـه ييرزنسى فرتـوت بـود هـم بـا ديـدن كارهـاى موسـى ييـش آمـد و دسـت موسـى را گرفت و گفت: ـ بيـا، بيابرويـم بـه خانـهى مـن. بـه مـن هـم كمـك كـن. نان هــــ مـرا هـم از تنور بيـرون بياور.

ييـرزن همسـايه همان طـور كـه دسـت موسـى را محكـم گرفتـه بـود او را به سـمت خانسه اش بـرد. خانـهى كوجگكى داشـت، يـك تنـور و يـك بغـل هيـزم كوشـهى 


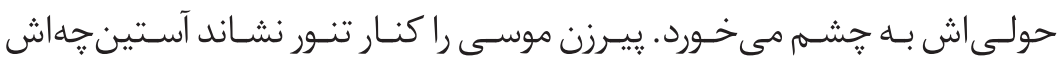
را بـه دسـت او داد. خـودش هـم شروع كرد بـه يههن كردن خميـر روى رفيـده.

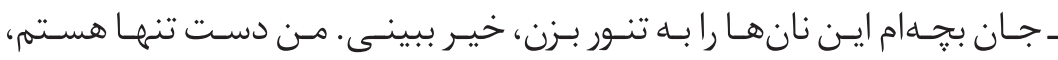
خيـر از جوانسىات ببينى. موسـى آسـتين جه بــه دسـت كار نـان زدن بـهـ تنــور راشروع كـرد. در خانسهى

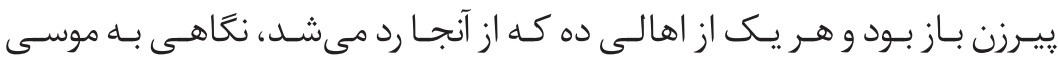

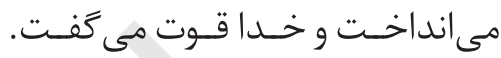

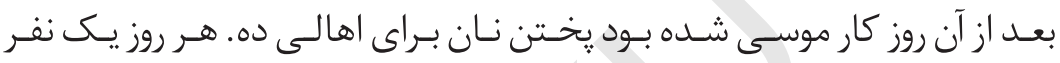

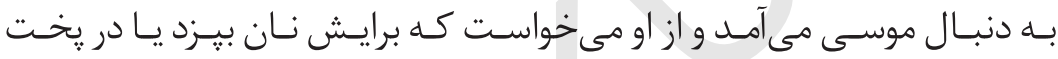

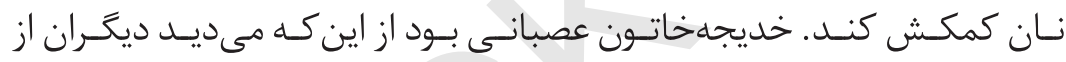
يسـرش كار مى كشـند و كارى را كـهـ تـا ديـروز خودشـان انجـام مى دادهانـد حـالا يسـر او بايـد انجـام بدهـد. ـ مخر دستهاىتان را بريدهاند كه يسر من بايد نانتان را بيزد. بعد با عصبانيت بيشتر به موسى مى كفت: ـ تـو نظركرده شـدهاى كـه حسمال مـردم بشـوى؟ هـا؟ بـراى حمالسى آمـدهاى؟ خر باركشـى تو؟

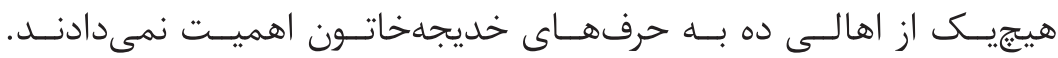

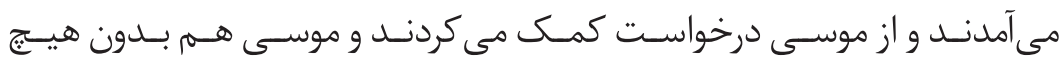

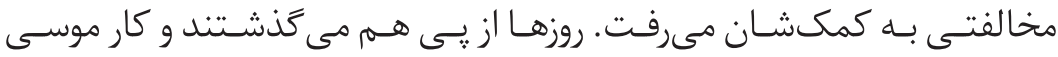

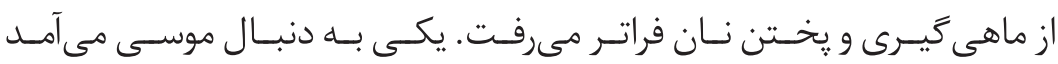




\section{معجزمى موسىى}

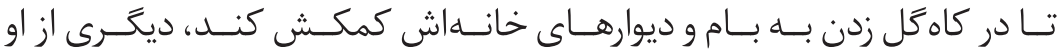

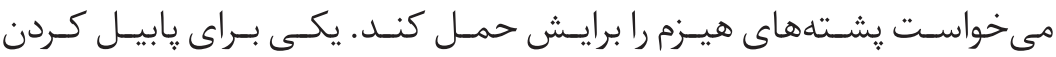
خـاك باغـش بــه دنبــال موسـى مى فرسـتاد و...

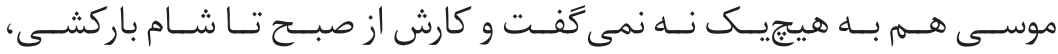

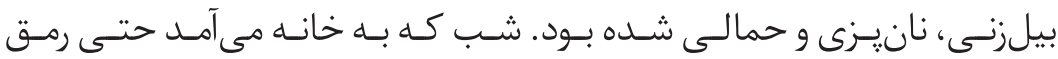

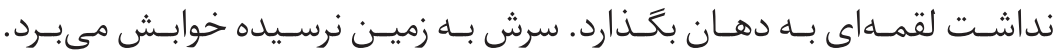

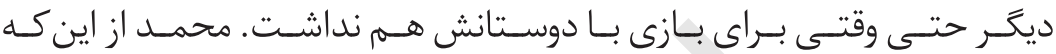
مى ديـد همبـازى و دوسـت صميمـى اش را دارد از دسـت مي دهـد ناراحـت بـود

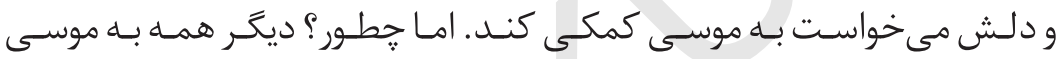

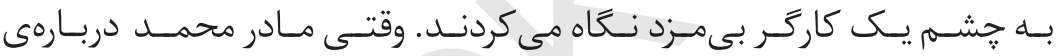
موسـى بـا خديجهذخاتـون صحبـت كـرد، خديجه خاتـــون بـى آب ديـده گريــه مى كـرد مى كفــت

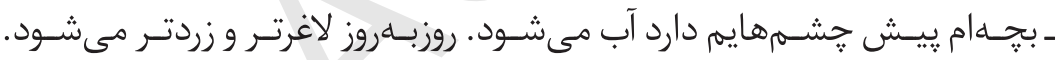

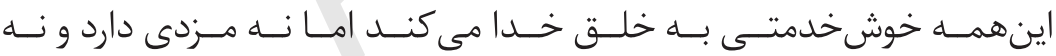

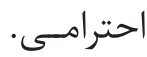
و هاى هاى گريه مي كرد. مادر محمد متفكرانه دستى به جانهاش كشيد و گفت:

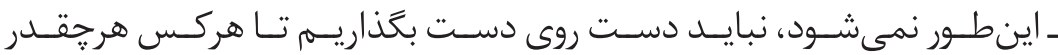

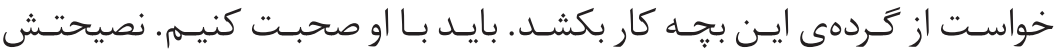
كنيسم. خـودش كجاست؟ 
خديجهخاتون اشكهايش را ياك كرد و جواب داد:

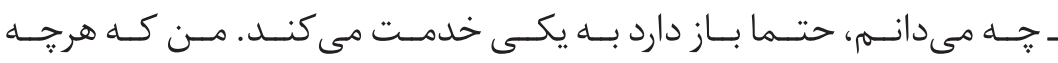

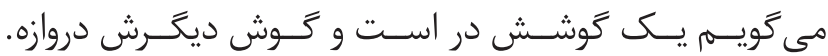
ـ محمد جان برو دنبالش و بياورش اينجا. بدو يسرم.

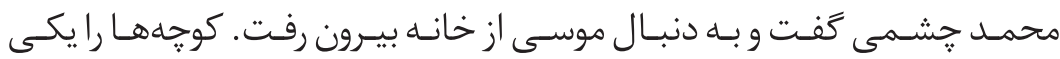

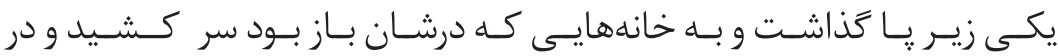
آخـر موسـى را بيـن دكان جمنـدى ديـد كه در حـال جابهجـا كـردن كيسـهـاى نخـود و مـاش و لوبيـا بـود. وارد مغــازه شــــ و سـلام كـرد و كفـت: ـ موسى من آمدهام دنبالت. بيا برويه. جمندى بين حرف محمد يريدو گفت: ـ كجامىبريش؟ مكر نمى بينى كار دارد. موسى كيسهاى را كه برداشته بود گوشهى دكان گذاشت و گفت:

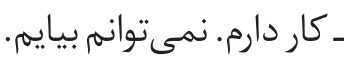
محمد حرصش گرفت. فكرى كرد و گفت: ـ خواهـرم افتـاده بيـن جـاه. فقـط تـو مىتوانسى او را از جــاه بيـرون بياورى. زودشـو بيـا كمك كن. موسـى تـا ايسن حـرف راشـنيد كيسـهها را رهـا كـرد و بـه دنبـال محمــ از دكان

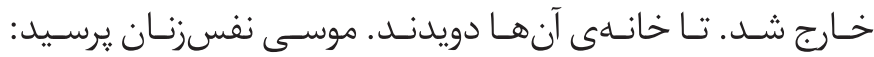

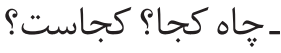

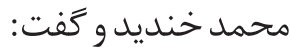




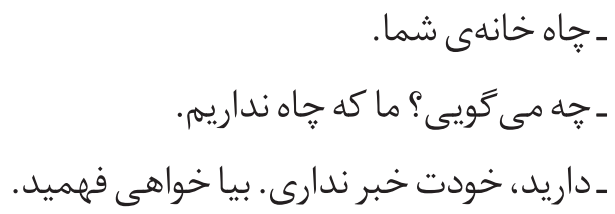
بعـد هــم دسـت موسـى را گرفـت و او را بـهـ داخـل خانهشــان تِيلـه داد و در را بسـت.

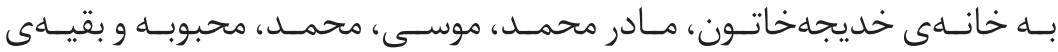
خواهرهايسش دور هـم نشسـته بودنـد. مادر محمد شروع كرد به صحبت كردن:

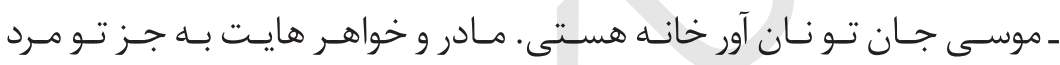

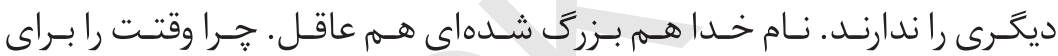

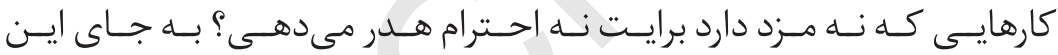
حمالى هـا و مزدورىهـا بـرو بـا شـبان خان كلـه را بجـــان و مـزدت را بخيـر. فكـر

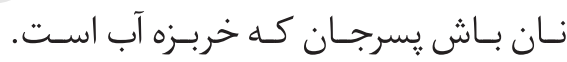

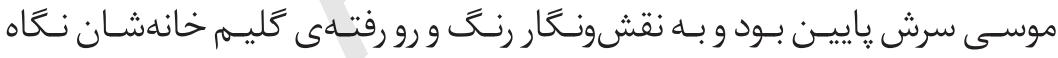
مى كرد. آهسـته كفتـ

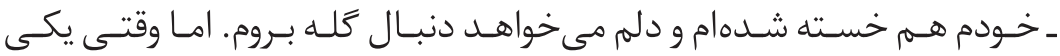

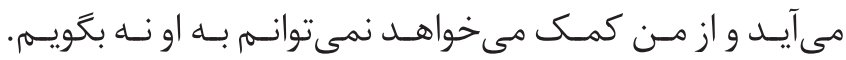
محمد هم حرف موسى را تأييد كرد و زفت:

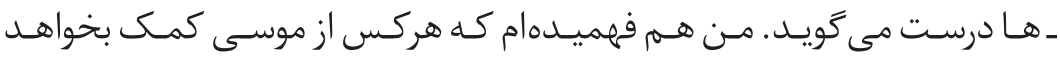

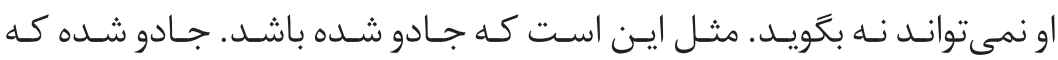




$$
\text { ـ - جادو؟ كى تو راجادو كرده؟ }
$$

ـ مثل جادو. شايد جادو نباشد. موسى آرام كفت: - نمسى

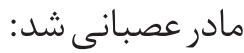
ـنمى دانم كه نشد جواب، از كى اينطور شدى تو؟ محبوبه مثل اين كه راز مهمى را كشف كرده باشد بشكنى زد و كفت: ـ فهميدم، فهميدم. از همان وقتى كه ييدا شد، اينطور شده. همه به محبوبه نگًاه كردند و منتظر ماندند تا ادامهى حرف هايش را بزند.

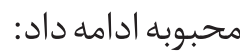

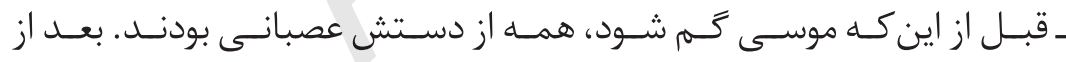

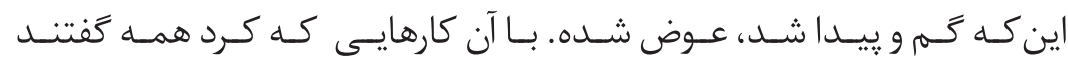
نظركـرده اسـت و بعـد از آن هركس هـركارى خواسـت موسـى برايسش انجـام داد. خديجهخاتون كه گيج شده بود گفت: - جه ميى گويى دخترجان؟

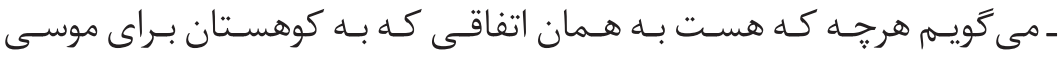
افتـاده مربـوط مـىشـود. بايـد يـادت بيايـد كـه وقتهى روى كـوه بـودى جـهـ شـده. 


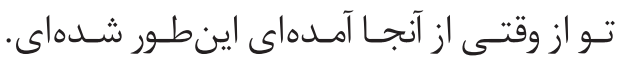
همه به موسى نغاه مى كردند و موسى غرق در افكار خودش بود: ـ من هيجزيزى به يادم نمى آيد. مادر عصبانى شد و اوف كشيد:

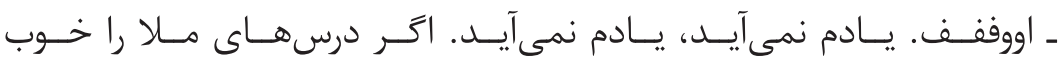
مى خوانـدى حـالا حافطـهات مثـل كـدوى خشـك نبـود. كلـهات خشـك شـــه كـه كار نمسى كنـد. موسى سرش راخاراند و جيزى نخفت. محبوبه زمزمه كرد:

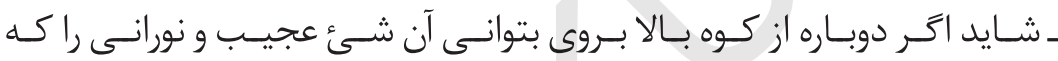

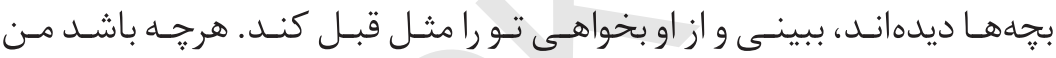
مطمــن هسـتم كـه كار، كار هـمان اسـت.

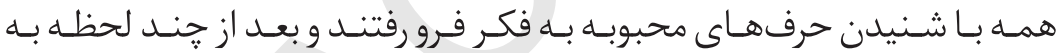
نشـانه تأييـد، شروع كردنـد بـهـ جنبانـدن سرهاىشـان. ـ خوبش، خوبش. درست مى ـ موسى بايد از آن كوه دوباره بالا برود. خديجهخاتون نَخران شد: ـاگر آن رانديد جه؟؟ ها؟ آنوقت بايد جه كار كند؟

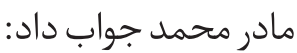

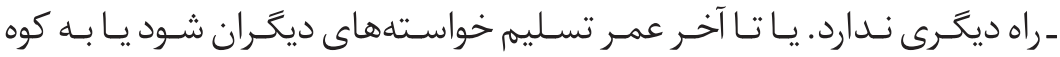

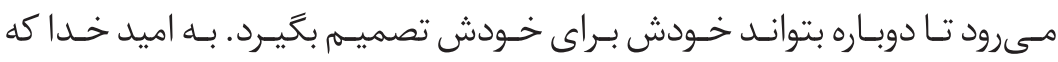




\section{معجزئى موسى}

درسـت مهىشـود.

خديجهخاتون هنوز دو دل بود:

- يعنى واقعا بفرستمش؟ كى راهى اش كنم؟ تنها بفرستمش؟

مادر محمد قاطعانه ياسخ داد:

ـ هرجه زودتر، بهتر. همين حالا است كه باز يكى بيايد دنبالش. هنـوز جملـهى مـادر محمـد تمـام نشـده بـود كـه در خانـه بـه صـدا درآمـد. همـهـ از جاى شـان يريدنـد. ـ محمـد تـو بـرو و در رابـاز كـن. هركسـى بـا موسـى كار داشـت بحَـو موسـى خانسه نيست و تـا شـب هـم برنمى گـردد.

محمـد بـا سرعـت بـه سـمت حولى دويـد و در رانيمهبـاز كـرد. بعد از جنـد لحظه در را بست و برگشت.

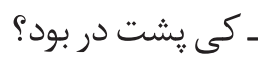

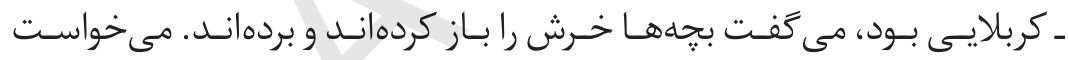
موسـى بـرود يشـت خـرش و يـيدايسش كند. مادر محمد كه از خشم سرخ شده بود رو به خديجهخاتون كرد و گفت:

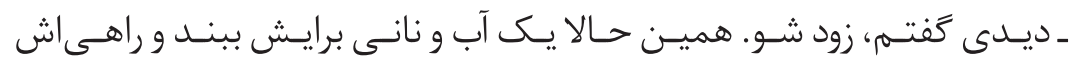
كن

محمد هيجانزده بالا يريد:

$$
\text { ـ مادرش هم با او مىروم. }
$$




\section{معجزمى موسىى}

ـ تو جطور مى خواهى از كوه بالا بروى؟ موسى نظركرده است، تو جى؟ موسى مثل اين كه جيزى به ياد آورده باشد كفت: ـ آن روز كه از كـوه بـالا مىرفتهم، يـك مسير يلكانى را يشت كـوه يـيـدا كـردم. آحر از آنجـا برويـهم بـالا رفـتن خيلـى سـادهتر مى شـود. آنوقـت محمـــ هـم مى توانـد بيايد.

محمد از خوشحالى دستهايش را به هم كوبيد: - برويم، برويم.

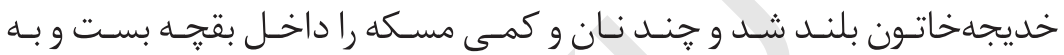
دسـت موسـى داد. يـك مشـك دوغ هـم بـه محمــد داد. ـ مواظب خودتـان باشـيد. هـوش كنيــ كار خطرناكى انجـام ندهيـد. مـا هـم تـا يـاى كـوه بـا شـما مى آييـم. موسى بلافاصله جواب داد: - مان

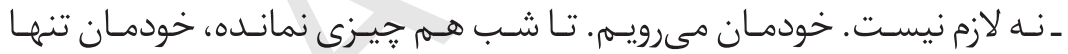

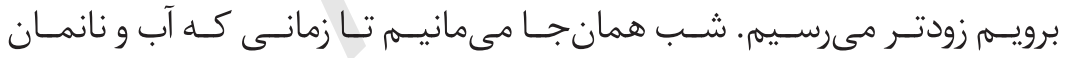

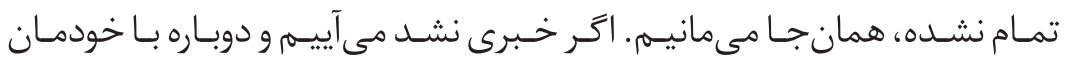
نـان مىبريسم. خيالتـان راحت. خديجهخاتون به جشممهاى موسى نگاه كرد: ـ تو كى اينقدر مرد شدى كه من نفهميدم.

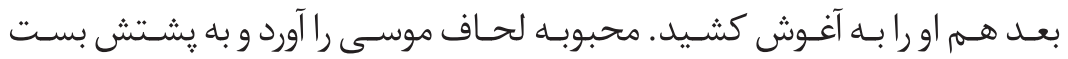
و كفت: 


$$
\text { ـ شب هوا سرد مىشود. }
$$

مـادر محمــد بعـد از اين كـهـ يـسرش را در آغـوش كرفت، قـرآن را از روى طاقِّهـ

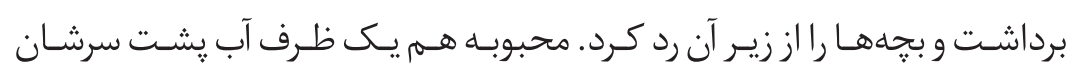
ريخت

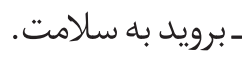

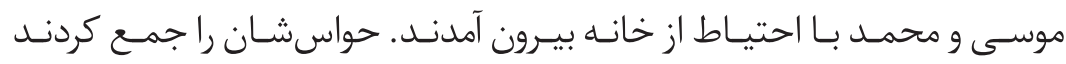

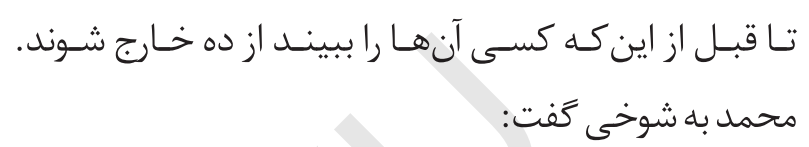
ـ عاقبت كمك بيشاز حد به ديخران، مثل دزدها فرار كردن است. و قاه قاه خندهشان بلند شد. خوشـبختانه كسـى بيـن كوجههــا نبـود و آنهــا بـهـ سرعت از ده خـارج شـدند و مسـيرى راكـه بـه سـمت كـوه مىرفت، بيـش خرفتنـد. 


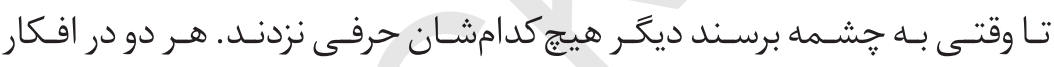

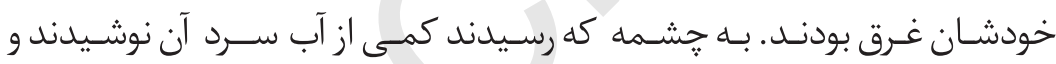

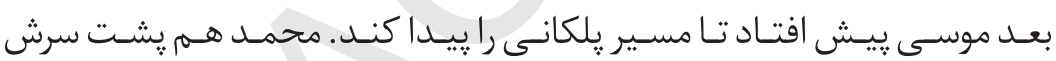

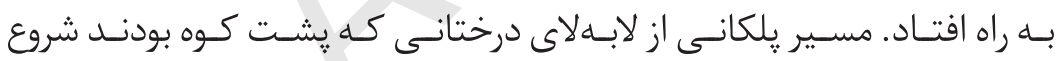
مـىشـد و تـا قلـه ادامسه داشـت. خيلى راحت از يله هاى سنگى بالا مىرفتند. محمد با تعجب يرسيد: - جرا تا بهحال كسى اين مسير را ييدا نكرده است؟ موسى شانههايش را بالا انداخت و جواب داد:

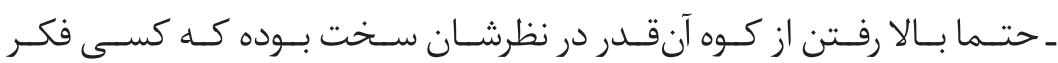
نمى كـرده يـك راه سـادهتر هـهم وجــود دارد. محمد لبخندزنان كفت: 
ـ ما اولين نفرهايى هستيم كه از اين مسير بالا مىرويم.

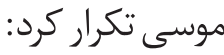

ـ اولين نفرها، شايد، مهمم اين است كه ييدايش كرديم. اول و آخر ندارد.

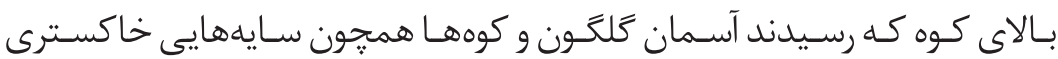

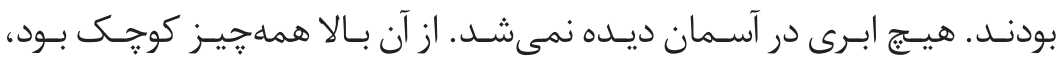

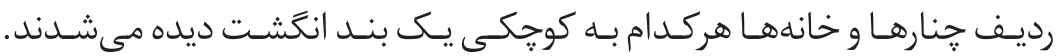

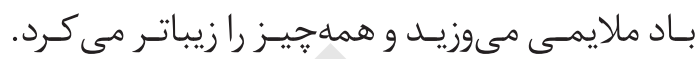
محمد از ديدن منظرهها حس عجيبى داشت، رو به موسى كفت: ـ حس عجيبى دارم، فكر كنم بايد نان ها را بخوريم.

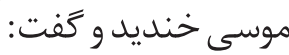

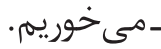

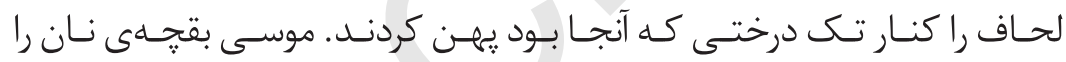

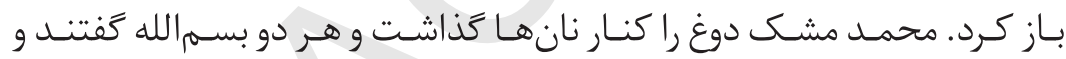
شروع كردنـد بـه خـوردن.

آسـمان كامـلا تاريـك شـد و وقـت نمايسش سـتارهها رسـيد. موسـى و محمـد روى لحـاف دراز كشـيدند و دستهاىشـان رازيــر سرشـان كذاشـتند و بــه آسـمان

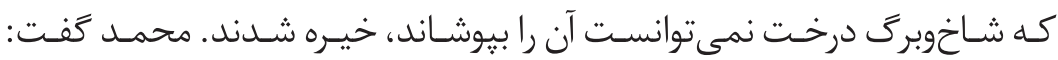
ـ موسى! تو مطمئن هستى كه مى خواهى مثل قبل بشوى؟ 


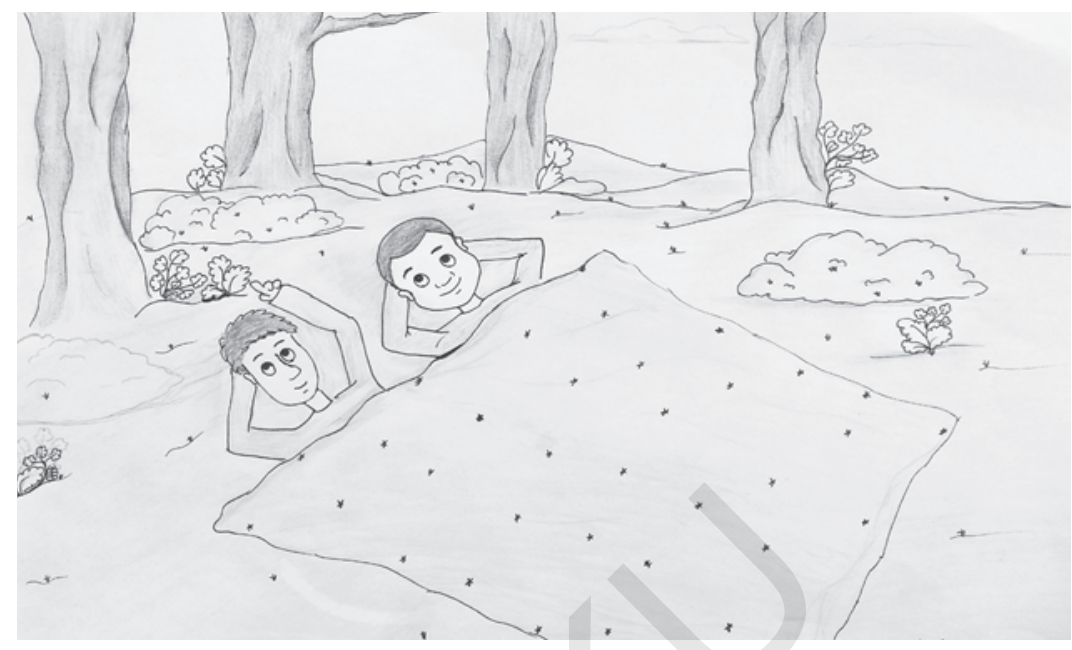

ـ منظورت جيست؟ واضح گَّ بزن.

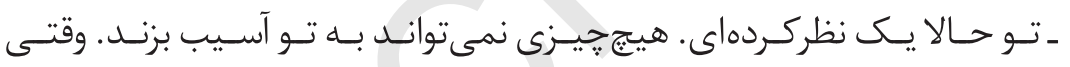

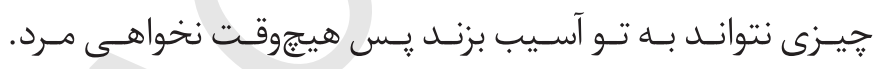

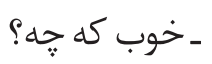

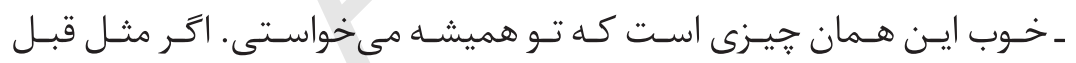

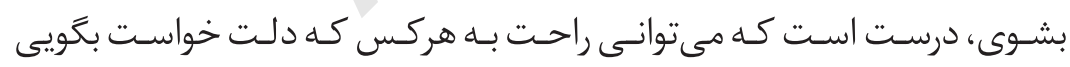

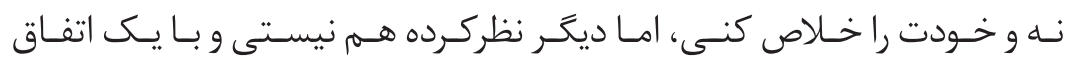

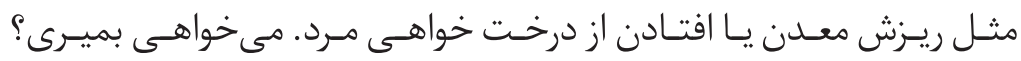

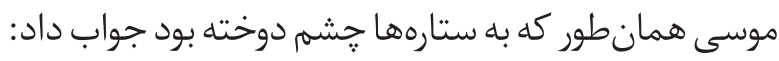

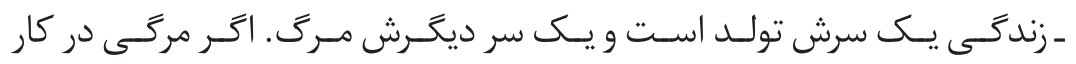

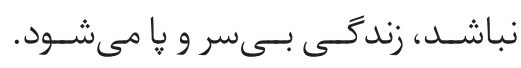

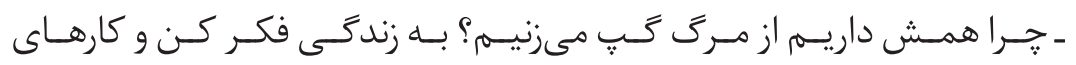




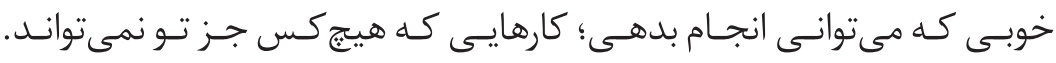

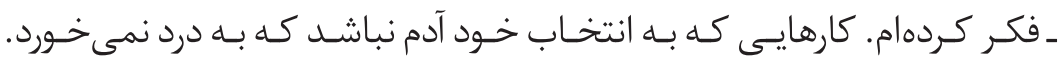

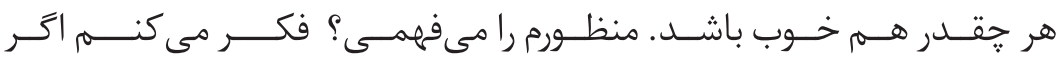

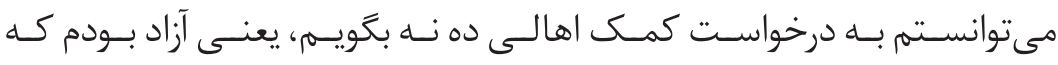

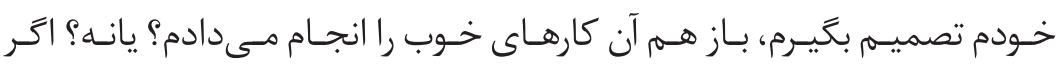

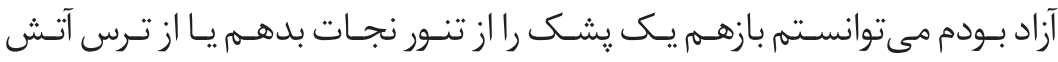

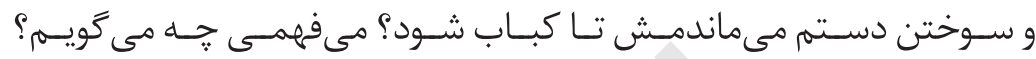
محمد متفكر جواب داد: هوم، مى فهممم، تو تصميمت راكرفتهاى.

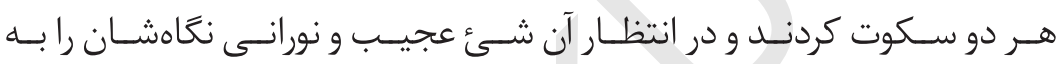
آسـمان دوختنــد.

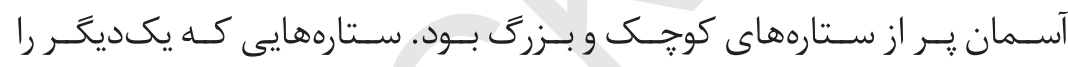

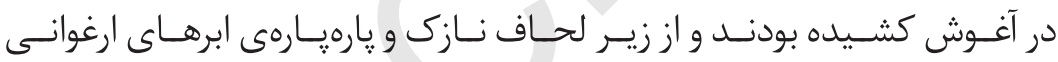

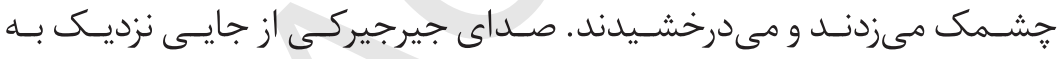

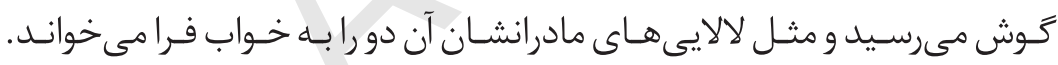

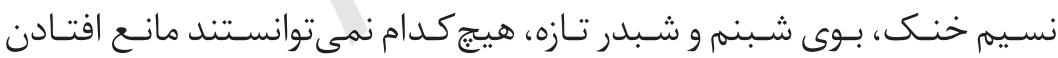

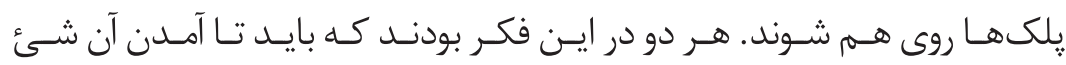

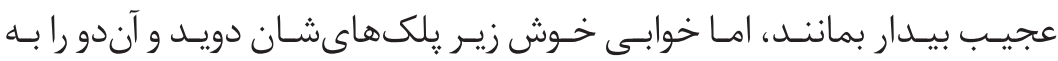
عـالم رؤيـا بـرد.

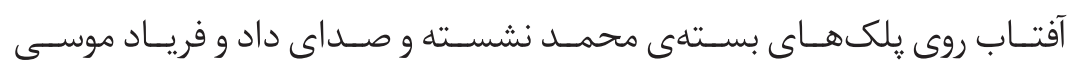
كوشـش را يــر كـرده بـود، امــا خـواب هنـوز دسـتبردار نبـود. ـ... 


\section{معجزهى موسى}

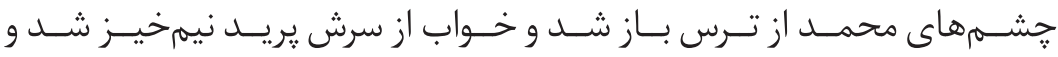
يرسـيد:

- جه شده موسى؟ جه شده تو را؟ موسى مثل مار زخمى به خودش مىي يجيجيد و ناله مى كرد:

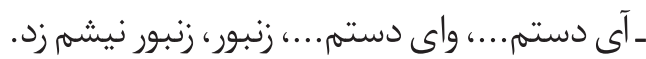
محمد بعد از جند لحظه سكوت از جا يريد و فرياد زد: ـ خدا راشكر، خدا را شكر.

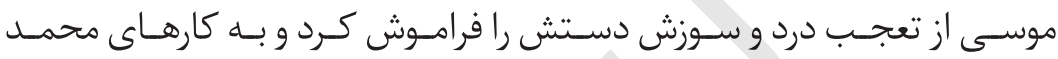
خيـره مانـد:

ـ تو را جه شده؟ زنبور مرانيش زده و توخدا را شكر مى كنى؟ محمد با خوشحالى شانهاي موسى راكرفت و گفت: ـ مـادرت درسـت مى گويـد؛ سرت يـك كـدوى خشـك اسـت. آن كـدو را بــهـار

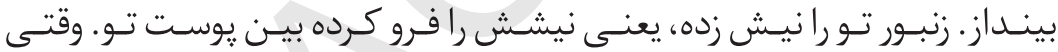

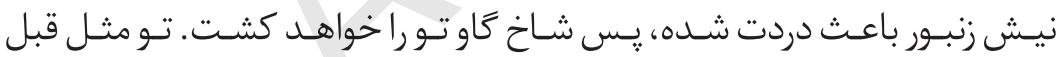
شـداى، بفهـم ديخـر. جشـمان موسـى بـرق زد و لب هايسش بـه لبخنـدى از هـم بـاز شد. درد را به كلى

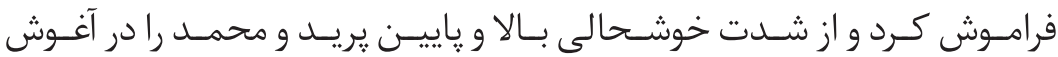
كرفت.

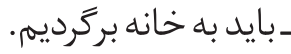
لحاف راجمع كردند. محمد براى اين كه موسى را امتحان كند كفت: ـ كمك كن و اين لحاف را به يشتت ببند و يايين ببر. 
معجزى موسىى

موسى باشيطنت جواب داد:

ـ نوبتى هم كه باشد، نوبت تو است محمدخان.

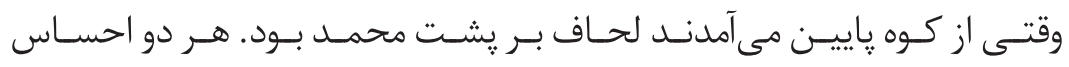

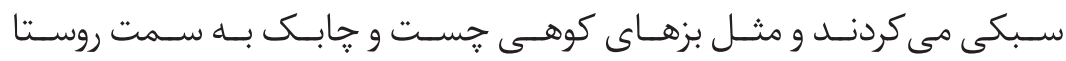

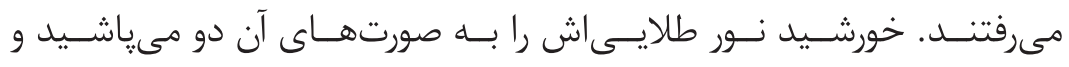
لبخندشـان را درخشـانتر ميىكـرد.

צيايان 


\section{Musa's Miracle}

\section{Zahra Naiemi}

$$
\text { يارهاى از متن }
$$

"... بسمىالله گفته و همانطور كه با مهن

3
3
0
$y$
2
3

دست راستش سنگى را مى گرفت، يك

يايش را بلند كرد و روى سنغى ديگر

كذاشت. كمى خودش را بالا كشيد. اين راين

بار با دست جֶٍ، سنگَى ديگر را كرفت و

باز هم خود را بالاتر كشيد. تمام مدت

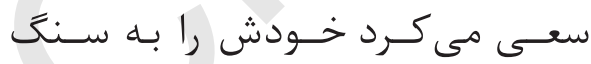

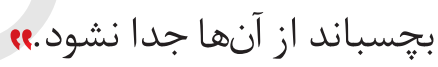

$\frac{\dddot{q}}{3}$ 